دراسة تقويمية لمقرر حقوق الإنسان بالمرحلة الجامعية في ضوء مرتكزات التربية المدنية د. محمد حسين على حمدان

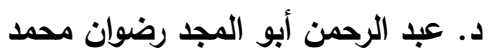

\title{
دراسة تقويمية لمقرر حقوق الإنسان بالمرحلة الجاهعية في ضوء هرتكزات التربية المدنية
}

د. محمد حسين على

مدرس بقسم المناهج وطرق التدريس

تخصص" مناهج وطرق تدريس اللغة العربية"

$$
\text { كلية التربية بقنا - جامعة جنوب الوادى }
$$

dr.mohamedhamdan@edu.svu.edu.eg
د. عبد الرحمن أبو المجد رضوان أستاذ مساعد بقسم أصول التربية تخصص " أصول التربية" كلية التربية بقنا - جامعة جنوب الوادي aradwn@yahoo.com 


\section{دراسة تقويمية لمقرر حقوق الإنسان بالمرحلة الجامعية في ضوء مرتكزات التربية المدنية}

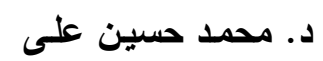

مدرس بقسم المناهج وطرق التدريس عليس

تخصص" مناهج وطرق تدريس اللغة العربية" التربية

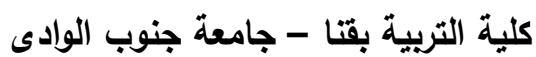

dr.mohamedhamdan@edu.svu.edu.eg
د. عبد الرحمن أبو المجد رضوان

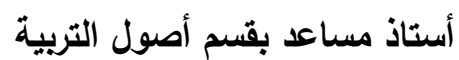

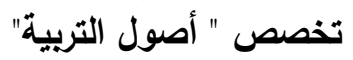

كلية التربية بقتا - جامعة جنوب الوادي لتوبة

aradwn@yahoo.com

\section{مستخلص:}

هدف البحث إلى التعرف على مستوى تتاول مقرر حقوق الإنسان بالمرحلة الجامعية

لمرتكزات التربية المدنية، وذلك بغرض تقويم ونطوير مقرر حقوق الإنسان بالمرحلة الجامعية

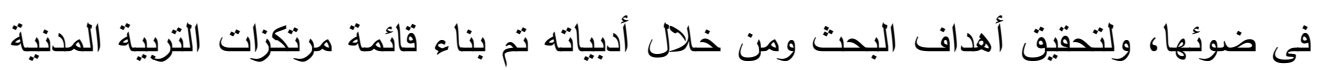
حيث اشتملت القائمة في صورتها النهائية على (r) أبعاد رئيسة للتربية المدنية يندرج تحتهاه

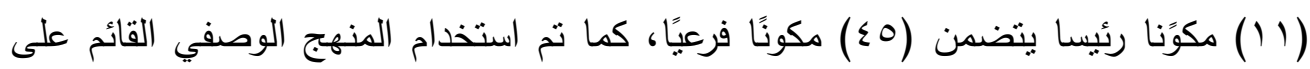
أسلوب تحليل المحتوي من أجل تحليل محتوي المقرر، والكثف عن مستوى تضدين أنسين أبعاد

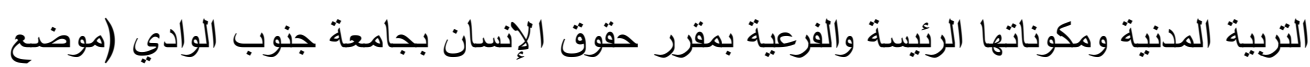
البحث).

توصلت النتائج إلى عدم تضمين المكونات الرئيسة والفرعية للتربية المدنية مجتمعة في مقرر حقوق الإنسان، حيث أن المكون الرئيس المتعلق بمهارات التفكير الإبداعي والناقد

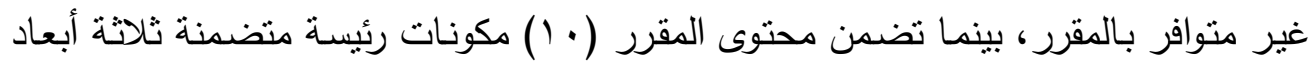

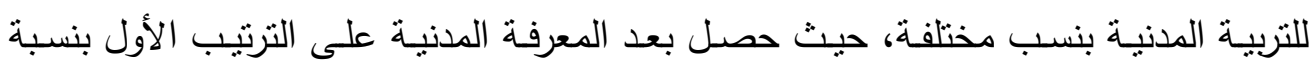

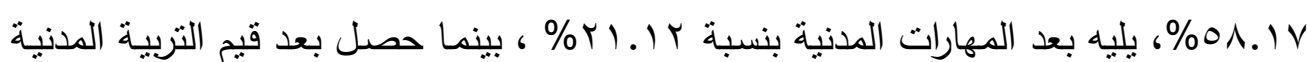

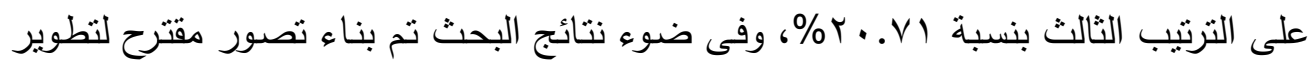
مقرر حقوق الإنسان بالمرحلة الجامعية، وأوصي البحث بضرورة تضمين محتوى مقرر حقوق

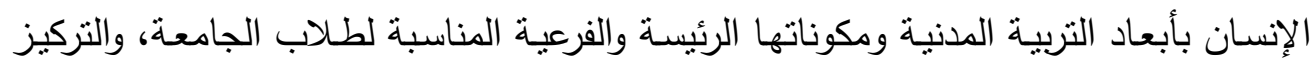
على المكونات غير الواردة بعد تحليل المقرر . الكلمات المفتاحية: حقوق الإنسان - أبعاد ومكونات التربية المدنية - المرحلة الجامعية. 
دراسة تقويمية لمقر حقوق الإنسان بالمرحلة الجامعية في ضوء مرتكزات التربية المدنية

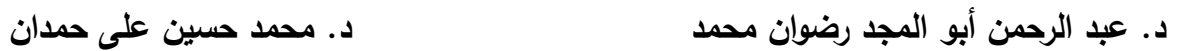

\title{
An Evaluation Study of the Human Rights Course at the University Stage in Light of the Dimensions of Civil Education
}

\author{
By \\ Dr. Abdul-Rahman Abul-Magd Radwan Mohammed \\ Assistant Professor of Foundations of Education \\ Qena Faculty of Education - South Valley University \\ E-mail: aradwn@yahoo.com \\ Dr. Mohammed Hussien Ali Hamdan \\ Lecturer of Curriculum and Arabic Methodology \\ Qena Faculty of Education - South Valley University \\ E-mail: dr.mohamedhamdan@edu.svu.edu.eg
}

\begin{abstract}
The current research aimed to identify the level of the dimensions of civil education in the human rights course at university stage through analyzing the content of the course to evaluate and develop it. Accordingly, the descriptive method that bases on content analysis was used aiming to recognize to what level the dimensions of civil education and its main and sub components were included in the human rights course at South Valley University. Further, a list of civil education pillars was prepared, and then presented to a jury of experts to ensure its suitability for university level. The list included 3 major dimensions. Each dimension has 11 major components, and each component includes 45 sub-components. The research findings revealed that the main components of civil education are not included in the human rights course at South Valley University. Besides, the main component of creative and critical thinking skills is not included. Actually, the human rights course contains of 10 major components including three main dimensions of civil education in different percentages: the knowledge of civil education $58.17 \%$, followed by civil skills at $21.12 \%$, while the values of civil education ranked the third with $20.71 \%$. Based on these results, it is recommended that the dimensions of the civil education that suit university students should be included in the human rights course.
\end{abstract}

Keywords: human rights, dimensions of civil education, university stage. 
دراسة تقويمية لمقرر حقوق الإنسان بالمرحلة الجامعية في ضوء مرتكزات التربية المدنية

د. محمد حسين على حمدان

د. عبد الرحمن أبو المجد رضوان محمد لردان

مقدمة:

ثمة مجموعة من المتغيرات والتحولات السياسية التى شهدتها المجتمعات بشكل عـام والمجتمـع المصـري خاصـة وأهمها موجـة التـــول الديمقراطي، وضـرورة تطبيـق مبـادئ الديمقراطيـة والحريـة والمساواة والعدالـة، والتى تتطلب مشـاركة الأفراد والقيـام بمسئولياتهم المجتمعية من أجل تحقيق الصالح العام. ولأن تغيير المجتمعات بالمعنى العام لا يكون إلا بتغيير البشر ، وتغيير البشر الثر الهر

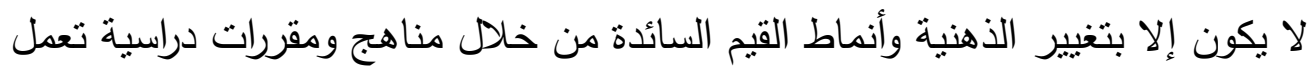
على إكسابهم المعـارف والمهارات والقيم التى تسـاعدهم على التغيير والتكيف مـع التغيرات الجديدة، فمن هنا لم يكن غريبًا أن يأتى التعليم في قلب كل مبادرات الإصلاح التى تسعى المجتمعات إلى إحداثها استجابة لهذه التحولات المجتمعية. وانطلاقًا من هذا الفهم يدافع سودر Soder عن افتراضـات ثناثة تتعلق بدور

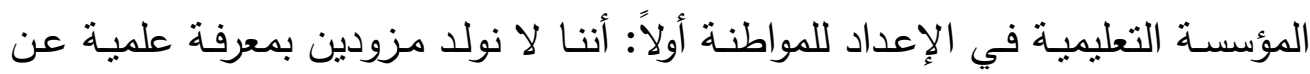
الحقوق والالتزامات كمواطنين في مجتمع ديمقراطى، فتلك أدوار مكتسبة تتم من خلال التعلم، وثانيًا: أن المكان الذى يتم فيه تعلم هذه الأمور هو المدرسة أو الجامعة، ثالثًا:

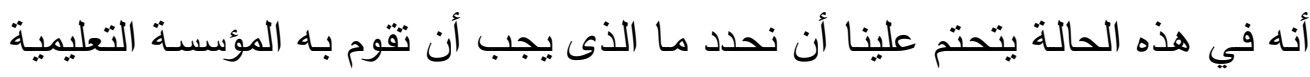
من أجل إعداد الطلاب للمواطنة في مجتمع ديمقراطي.

(•) (Soder, 1997: 45)

وهذا ما أكده البيان الختامى للملتقى الدولى حول التربية للمواطنة، والذى عقد في مدينة بيروت تحت رعاية الاتحاد العالمى للمؤسسات العلمية UNSCIN حيث أكد على أن "تتمية معارف وقيم المواطنة وحقوق الإنسان هي قضية تربوبة بامنياز ، تتولى التى

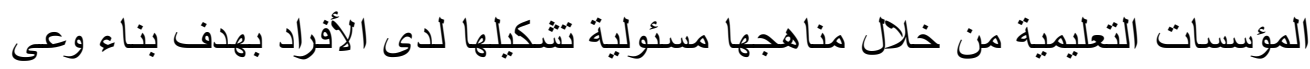

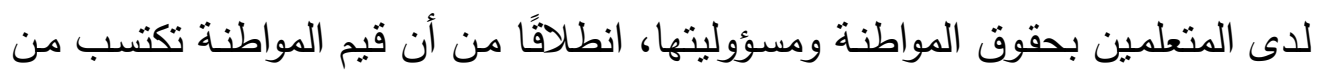

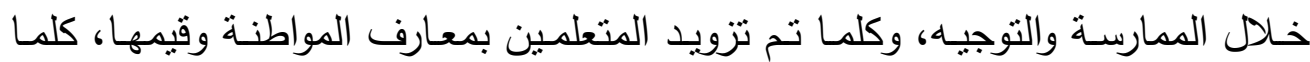


دراسة تقويمية لمقرر حقوق الإنسان بالمرحلة الجامعية في ضوء مرتكزات التربية المدنية

د. محمد حسين على حمدان

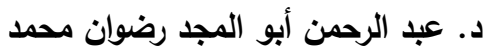

زادت فرصــة مشـاركتهم المسـتقبلية فـي شـئون وطـنهم، وارتفعـت نسـبة انخـراطهم بمجتمهر، كما أكد أيضًا على ضرورة نشر مفاهيم التربية المدنية في سائر المقررات الدراسـية، وإجـراء مراجعـة شـاملة لجميـع المقررات بغـرض التحقـق مـن موضـوعاتها والأهداف التى وضعت من أجلها" .

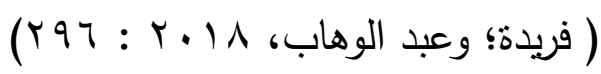

ونظرا لإرتباط حقوق الإنسان بالديمقراطية ومسيرة التنمية بمفهومها المجتمي

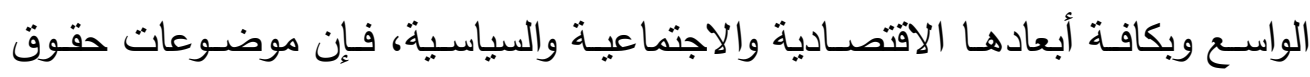
الإنسـان ظلت تـدرج ضـمن مقررات الأفرع المختلفـة للمعـارف الطبيعيـة والإنسـانية والاجتماعية فى جامعات دول الغرب الديمقراطي، ثم أضـت دراسـة مقررات حقوق الإنسان من الموضوعات التى تحظي بالاهتمام فى جل دول العالم التى تتطلب تحولاً نحو شكل الحكم الديمقراطي أو التى تتطلع إلى ذلك الثكل. بلإن.

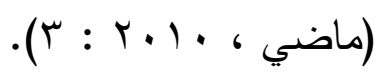

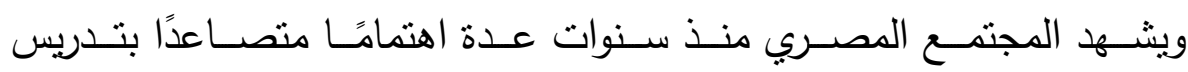
موضوعات حقوق الإنسان، حيث نزايد الاهتمام بتدريس حقوق الإنسان على المستوى

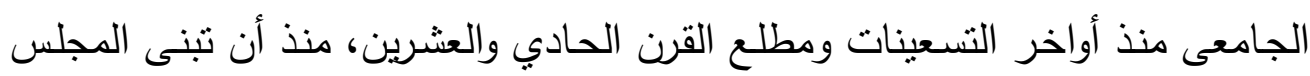

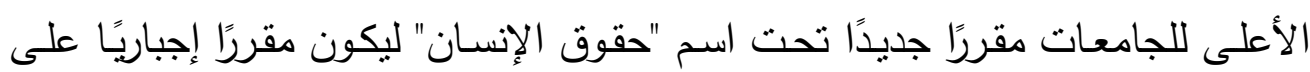
جميع طـلاب الجامعات المصرية، يدرس في الفرقـة الأولى أو الثانيـة حسب اللـوائح

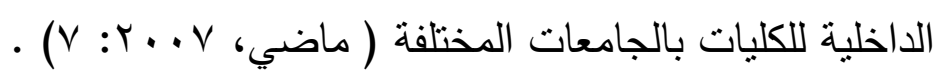
فالمجتمع المصرى بشكل خاص فى حاجة ماسـة إلى نوع من التربية، تمكنه

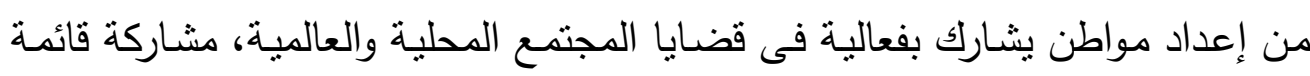

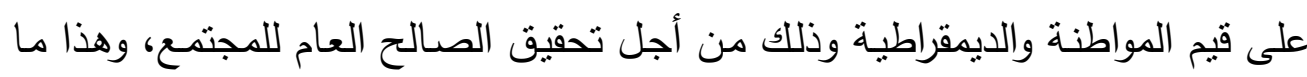
تسهح بـه التربية المدنية "حيث أنها مسئولة عن نتمية مهارات المواطنة والتفكير الناقد

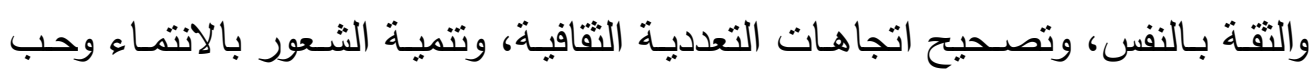

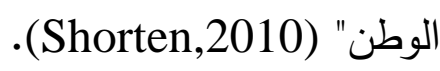


دراسة تقويمية لمقرر حقوق الإنسان بالمرحلة الجامعية في ضوء مرتكزات التربية المدنية د. محمد حسين على حمدان د. عبد الرحمن أبو المجد رضوان محمد لديد

فالتربيـة المدنيـة تهـتم فـى الأسـاس بالمواطنـة الواعيـة، والفعالـة والمسـئولية الاجتماعية والأخلاقية فى مجتمع ديمقراطى، وتعنى بتتمية القيم والاتجاهات التى تدعم

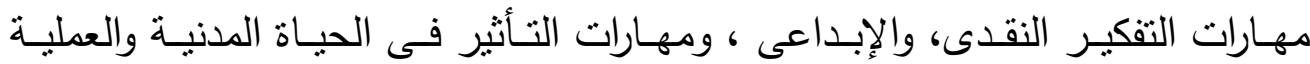
السياسية، ونجدها قبل كل شئ تهتم بإعداد وتكوين المجتمع المدنى الذى يقوم على المشـاركة الإيجابيـة والتعدديـة والمحاسبية والثـفافية والعـلـ، ودعم الثـعور بالفعاليـة

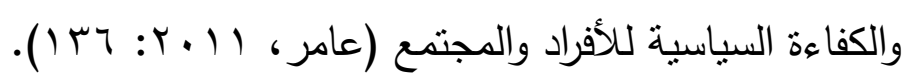

وتتضـح أهمية التربية المدنية كونها تسهم فى تربية المواطنة باعتبارها عملية

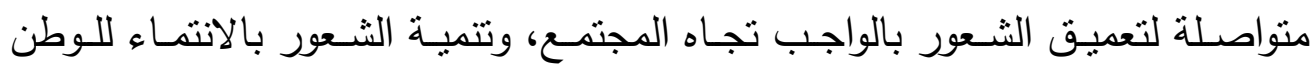
والاعتـزاز بـه، وغـرس حـب النظـام والاتجاهـات الوطنيـة، والتفـاهم والتعـاون بـين

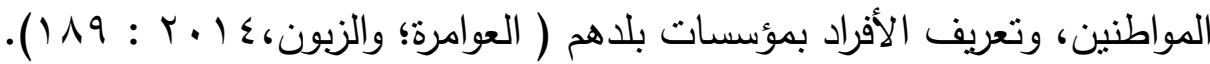
فالتربية المدنية ضرورة مجتمعية للتدريب والتعليم والممارسة للمعارف والمهارات والقيم والاتجاهـات المرتبطة بالحريـة والمواطنة وحقوق الإنسان، بهدف تتمية الثـعور بالمسئولية الاجتماعية وترسيخ قيم الولاء والانتماء للوطن، والتأكيد على الهوية الثقافية

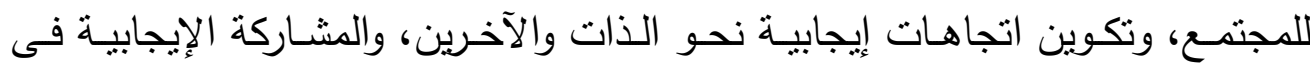
الحضارة الإنسانية (على، 7 ( • ب : • (1). وعليه فالتربية المدنية ضرورة حياتية لتحرير الفرد وتزويده بالمعارف والمهارات والقيم والاتجاهات اللازمـة لبنـاء مستقبل أفضل، فهي عملية تنقيفيـة توعويـة وهي من ون أفضل المحتويات التى تبدأ منها دراسة حقوق الإنسان وتعلمها، لذا سعي البحث الحالي للتعـرف على مستوى تتـاول مقرر حقوق الإنسـان بالمرحلـة الجامعيـة لأبعـاد التربيـة المدنية ومكوناتها الرئيسة والفرعية بغرض تقويمه وتطويره. 
دراسة تقويمية لمقرر حقوق الإنسان بالمرحلة الجامعية في ضوء مرتكزات التربية المدنية

د. محمد حسين على حمدان

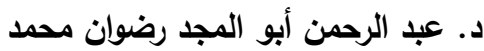

مشكلة البحث وأسئلته:

للمرحلـة الجامعيـة أهميـة كبيرة فى تتميـة وصقل البنـاء الاجتمـاعي للطـلاب،

وذللك لما يتوافر للجامعة من أنشطة مختلفة تسهم فى ذلك كالنوادي والأسر والاتحادات الطلابية، وكلما توافرت أجواء الديمقراطية بها كلما نقل الطلاب تجاربهم خارج أسوار الجامعة، وكلما ساهموا فى نرسيخ وتعزيز مكونات التربية المدنية فى المجتمع بأكمله. وفي إطـار ذلك اهتمـت الجامعـات المصـرية بتدريس حقوق الإنسـان ومنهـا

جامعة جنوب الوادي، حيث وضـعت مقررًا على مستوى جميع الكليات، وهو مقرر إجباري لجميع الطلاب سواء الكليات النظريـة كالآداب أو التربية، أو الكليات العملية منل الطب البشري والعلوم والصيدلة، وقد تم إعداد محاضرات المقرر من قبل أساتذة كلية الحقوق بالجامعة ذاتها، ويقوم بتدريس هذه المحاضرات أعضاء هيئة التدريس هن هن

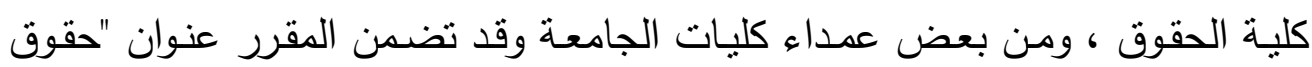

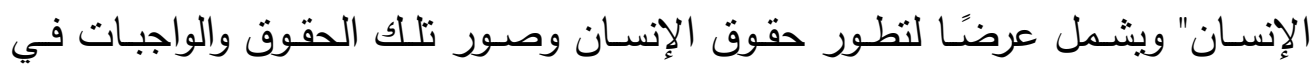
المواثيق والقوانين الدولية.

وبالرغم من تطبيق هذه التجربة على مستوى الجامعات المصرية إلا أن هناك

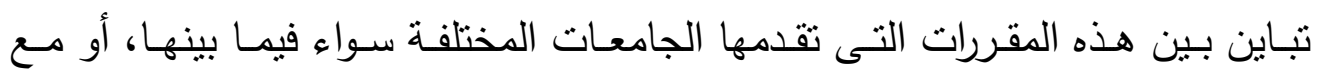
المعايير المتعارف عليها فى حقوق الإنسان بجامعات العالم من حيث مضمون المقرر وطرق التدريس والأنشطة التعليمية المقدمة، وضعف ربط مقررات حقوق الإنسان فى لهى

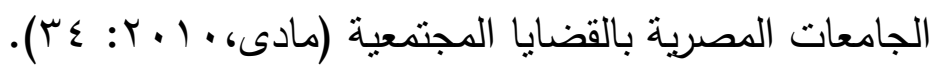
فقد أكدت دراسـة قزامل (Y Y r r) إلى عدم توظيف مقرر حقوق الإنسان لدى طلاب الجامعة مع التطبيقات والقضايا المعاصرة، وعدم وصولهم إلى مستوى التمكن والوعي بمفاهيم ومصطلحات مقرر حقوق الإنسان. ويشير واقع تدريس حقوق الإنسان بمصر بشكل عام، وما يرنبط به من مفاهيم

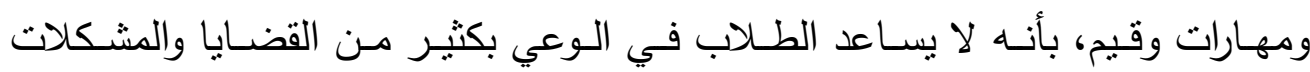

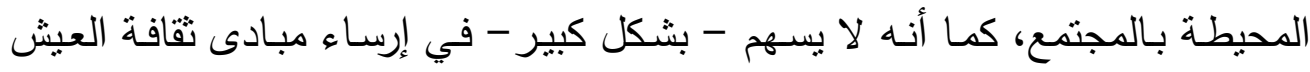


دراسة تقويمية لمقر حقوق الإنسان بالمرحلة الجامعية في ضوء مرتكزات التربية المدنية

د. محمد حسين على حمدان

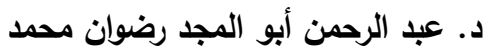

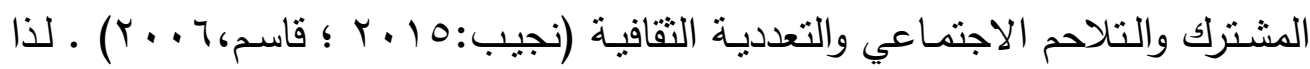

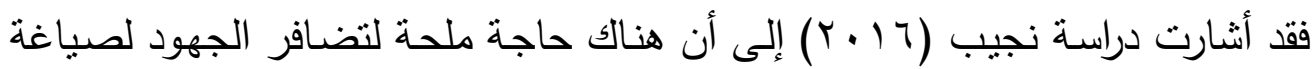
رؤيـة فكريـة أكثر شمولاً لتفعيل مشـاركة الثباب في السياسـات المجتمعيـة، من خـلال بناء برامج للتربية المدنية في منظمات المجتمع المدنى ومؤسسات التعليم •

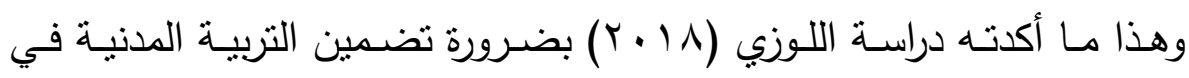

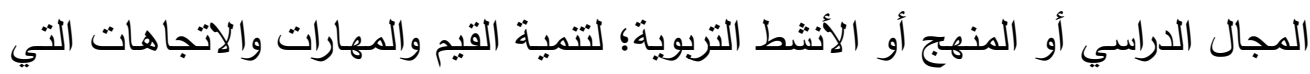
تمكـن المـتعلم مـن تحمـل المسئولية الاجتماعيـة والمشــاركة المجتمعيـة والسـلوكيات الإيجابية، "فمسئولية التربية المدنية تكمن بأنها وسيلة مهمة لتكوين الثخصية الواعية اجتماعيًا وسياسيًا من جهة، والقادرة على التعايش مـع الآخرين وفق مبادئ إنسانية

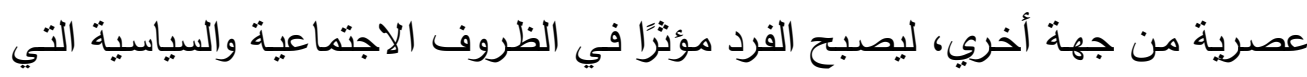
يعيش فيها وليس مجرد متلقي سلبي يتأثز بها ويستجيب لها".

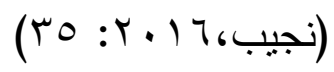

وقد أجري الباحثان فحصًا سريعا لمحتوي مقرر حقوق الإنسان بجامعة جنوب

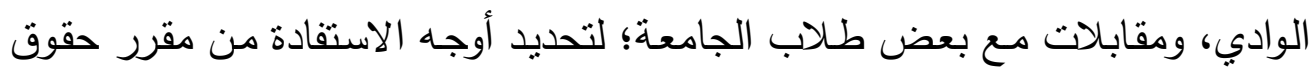
الإنسان، حيث اتضح أن المقرر بـ الكثير من المفاهيم والمعلومات والحقائق المتعلقة

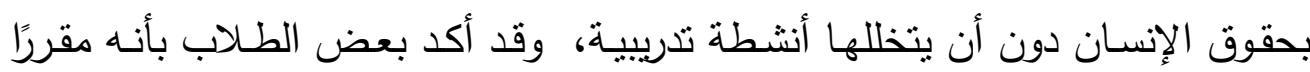

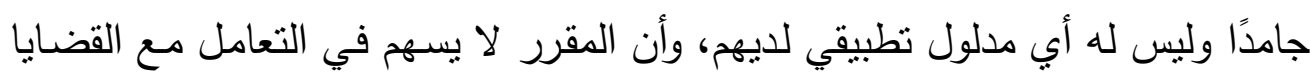
والمستجدات العصرية والتعامل معها. وفي ضـوء مـا سبق يمكن أن تتحدد مشكلة البحث الحالي في وجود بعض ونه أوجه القصور في مقرر حقوق الإنسان بالمرحلة الجامعية، واختلاف تدريسه من كلية

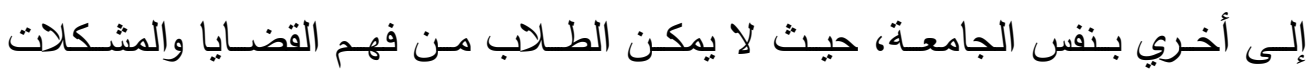
المجتمعية والاسهام فى الوعي الإيجابي بها، ومن ثم تبدو الحاجة ماسـة لتقويم المقرر ليتسنى تحديد نقاط القوة والضعف فيه، وتقديم تصور لتطويره بما يواكب المستجدات العصرية فى المجتمع المصري لذا تحددت مشكلة البحث فى السؤال الرئيس التالي: 
دراسة تقويمية لمقرر حقوق الإنسان بالمرحلة الجامعية في ضوء مرتكزات التربية المدنية د. دممد حسين على حمدان

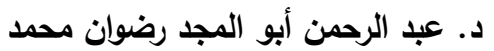

مـا مستوى تضـمين مقرر حقوق الإنسـان بجامعـة جنـوب الـوادي لمرتكزات

التربية المدنية ؟ ويتفرع منه الأسئلة الفرعية التالية:

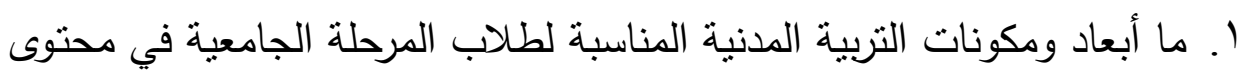
مقرر حقوق الإنسان؟

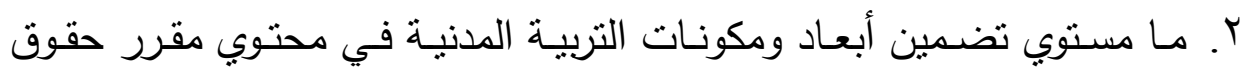

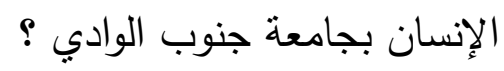

r. ما التصور المقترح لتطوير محتوي مقرر حقوق الإنسان بالمرحلة الجامعية فى لـى

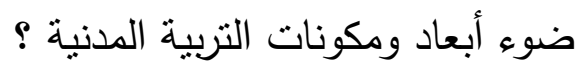
أهداف البحث:

1 - الكثف عن أبعاد التربية المدنية ومكوناتها الرئيسة والفرعية المناسبة لطلاب المرحلة الجامعية بمقرر حقوق الإنسان. r- التعرف على مستوي تضمين أبعاد ومكونات التربية المدنية فى محتوي مقرر حقوق الإنسـان بجامعـة جنـوب الـوادى والمتمثلــة بالأبعـاد الرئيســة المعرفيـة والمهارية والوجدانية ومكوناتها الرئيسة والفرعية.

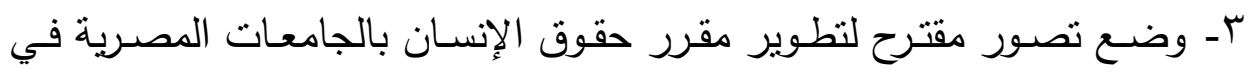
ضوء مرتكزات التربية المدنية. أهمية البحث: أنو: تتبع أهمية البحث من الاعتبارات التالية:

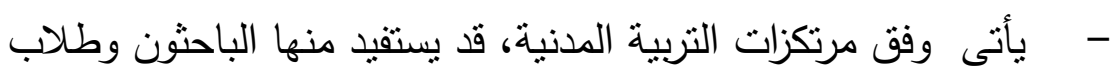
الدراسات العليا فى هذا المجال مما يوفر عليهم الوقت والجهد. 
دراسة تقويمية لمقرر حقوق الإنسان بالمرحلة الجامعية في ضوء مرتكزات التربية المدنية د. محمد حسين على حمدان د. عبد الرحمن أبو المجد رضوان محمد لديد محدات البحث : اقتصر البحث الحالي على: - تحليل وتقويم محتوي جميع الموضوعات الواردة بمقرر حقوق الإنسان بجامعة

$$
\text { جنوب الوادي (موضع البحث). }
$$

- تحليل محتوى مقرر حقوق الإنسـان بجامعة جنوب الوادي فى شـهري نوفمبر

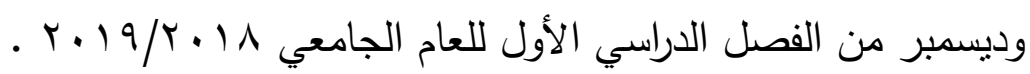

- التربية المدنية بمرتكزاتها الرئيسة الثلاثة " المعارف المدنية والمهارات المدنية

$$
\text { مصطلحات البحث: }
$$

يمكن تعريف مصطلحات البحث إجرائيا وفق ما يلي:

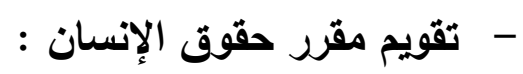

عملية منهجية منظمة تقوم على أسس علمية بغرض إصدار حكم دقيق وموضوعي على محتوي مقرر حقوق الإنسان وذلك بالاستتاد إلى مرتكزات التربية

$$
\text { المدنية المستخلصة من الأدب التربوي. - مقرر حقوق الإنسان: }
$$

مادة تعليمية دراسية إجبارية على جميع طلاب جامعة جنوب الوادي بكلياتها المختلفة

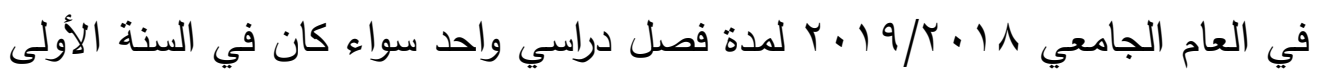
أو الثانية وفق اللوائح الداخلية لكل كلية بالجامعة.

$$
\text { - مرتكزات التربية المدنية }
$$

الدعائم والأسس التي تتكامل فيما بينها لإعداد الطالب صاحب السلوك المدني المرغوب فيه، المتفاعل مع الأحداث فى محيطه المحلى والدولى، من خلال ممارسة

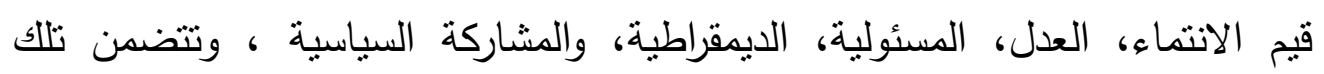
الدعائم ثلاثة مرتكزات رئيسة، هي: المعارف المدنية والمهارات المدنية والقيم المدنية . 
دراسة تقويمية لمقر حقوق الإنسان بالمرحلة الجامعية في ضوء مرتكزات التربية المدنية

د. محمد حسين على حمدان

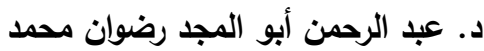

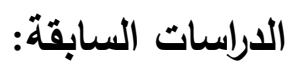

تتاول البحث عرض الدراسات السابقة من خلال محورين رئيسين، ووفق

التزتيب الزمنى من الاحدث للأقدم ويمكن تتاول ذلك تقصيليًا على النحو التالى : تمنل المحور الأول في الدراسات المتعلقة بالتربية المدنية ومنها دراسة اللوزي

(1) (1) والتى هدفت إلى تعرف فاعلية وحدة دراسية مقترحة قائمة على أبعاد التربية المدنية بمنهج التربية الأسرية في تتمية قيم الأمن الفكري ومهارات اتخاذ القرار الأخلاقي لدى طالبات الصف الثالث الإعدادي. استخدم البحث المنهج التجريبي ذي التي التهن

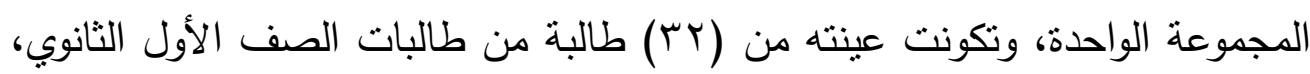
وقد اشتملت أدوات البحث علي أداتين هما: اختبار اتخاذ القرار الأخلاقي، ومقياس قيم الأمن الفكري وتضمن (التسامح الفكري، الحوار الإيجابي، الوعى بحقوق الإنسان، التعايش السلمى مع الآخرين، الانتماء والولاء الوطني، المسئولية الاجتماعية). أوضحت النتائج وجود فرق دال إحصائيًا بين متوسط درجات الطالبات عينة البحث في البه التطبيق القبلي والبعدي لمقياس الأمن الفكري، وفى كل بعد من أبعاده على حده لصالح التطبيق البعدي، وأظهرت النتائج أيضًا وجود فرق دال إحصائيًا بين منوسط التئ درجات الطالبات عينة البحث في النطبيق القبلي والبعدي لاختبار اتخاذ القرار الأخلاقي لصالح التطبيق البعدي، كما أظهرت النتائج وجود علاقة ارتباطية طردية موجبة ودالة إحصائًًا بين اختبار اتخاذ القرار الأخلاقي ومحاور مقياس الأمن الفكري.

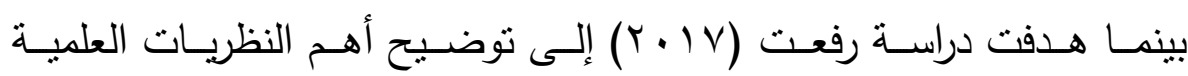

والتوجهات الفلسفية التي يستتد إلبها المجتمع المدني، وتحديد الأسس الفلسفية والفكرية

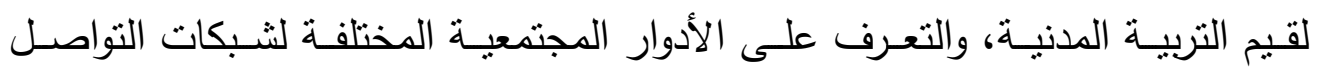
الاجتماعي ودورهـا في تتمية الوعى بقيم التربية المدنية، ووضـع تصور مقترح لتفعيل دور شبكات التواصل الاجتماعي في تتمية الوعى بقيم التربية المدنية في ضوء نظريات

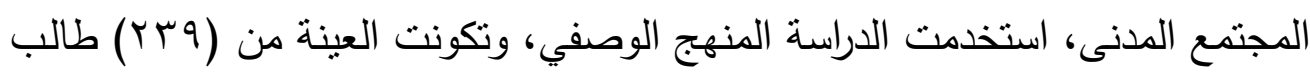
من طـلاب جامعـة بنها، تم اختبـارهم بشكل مقصـود مـن بين طـلاب الفرق النهائيـة 
دراسة تقويمية لمقرر حقوق الإنسان بالمرحلة الجامعية في ضوء مرتكزات التربية المدنية

د. محمد حسين على حمدان

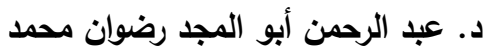

بكليـات العلوم والهندسـة والآداب والتربيـة (كليتان عمليتان وكليتان نظريتان).أظهرت

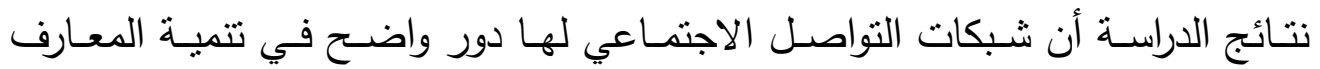
والمهارات المدنية، كما كثفت وجود قصور في دور شبكات التواصل الاجتماعي في تتمية القيم المدنية.

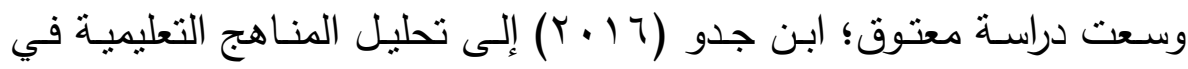

مرحلة التعليم الابتدائي للتعرف على قيم المواطنة التي تتضمنها مناهج التربية المدنية في مرحلة التعليم الابتدائي، حيث استخدم منهج تحليل المحتوى، وكانت عينة البحث متمنلـة في منـاهج التربيـة المدنيـة للسنوات الأولى والثانيـة والثالثة والرابعـة والخامسـة بمرحلة التعليم الابتدائي الصـادرة عام | ( ـ ب، وتوصلت الدراسة إلى عدة نتائج منها أن مناهج التربية المدنية في مرحلة التعليم الابتدائي سعت إلى تتمية قيم المواطنة لدى الدى

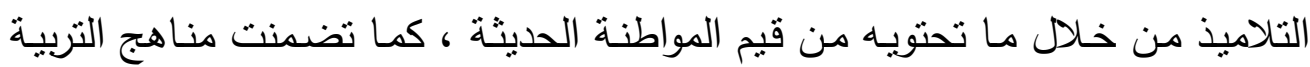
المدنية في مرحلة التعليم الابتدائي مجموعة من قيم المواطنة والتى لم تتوزع بشكل

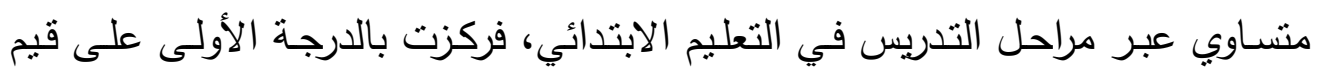
الواجبـات، في المرتبـة الثانيـة نجد قيم الانتمـاء للوطن، واحتلت قيم الحقوق المرتبـة الثالثة، بينما كانت قيم البيئة في المرتبة الرابعة في محتوى مناهج التربية المدنية وأخيرًا احتلت قيم الديمقراطية المرتبة الخامسة. وكثفت دراسة نجيب (7 1 ـ r) البيانات والمعلومات المناحة حول برامج التربية المدنية، التي تستخدمها بعض المنظمات والجمعيات في مصر، وتحديد القضايا والموضوعات التي اهتمت بها المجموعات المتاحة من برامج التربية المدنية، وحصر بهر الموضوعات التي كان الاهتمام بها أقل مقارنة بغيرها، بالإضافة إلى ذلك تحديد قائمة بأولويات الأهداف والموضوعات التي يحتاجها تصميم برنامج نربوي فعال للتربية المدنية في ضوء ما أسفر عنه حصر وتصنيف الموضوعات، وتقييم الموضوعات والبرامج المتاحة، وقد بلغ عدد الكتب والتقارير وأدلة التدريب التي تم تحليلها(·ب) كتابًا وتقريرًا تمنت في مجموعها(Y) برنامجًا من البرامج التي تنتاول مجالات 
دراسة تقويمية لمقر حقوق الإنسان بالمرحلة الجامعية في ضوء مرتكزات التربية المدنية

د. محمد حسين على حمدان

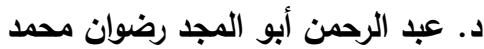

وموضوعات تتدرج في إطار التربية المدنية، هذا وقد أظهرت نتائج التقرير أنه يمكن ترتيب المجالات ذات الأولوية في برامج التربية المدنية للمنظمات الأهلية في: (تعليم حقوق الإنسان، مهارات المشاركة، برامج المواطنة، برامج العيش المشترك) ومن خلال بهل

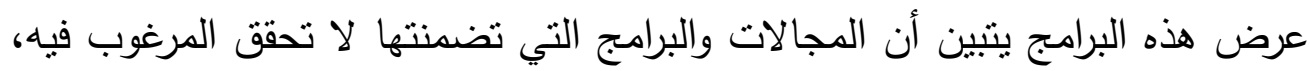
من إعداد مواطني المستقبل للحياة المدنية المصرية حيث توجد قضايا لا تزال بحاجة

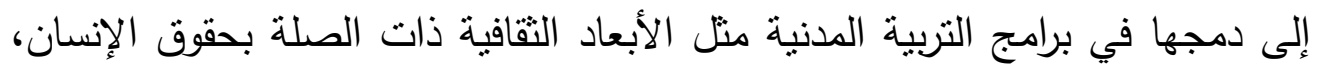
والعلاقة بين الديموقراطية، والتزام المجتمع بحقوق الإنسان.

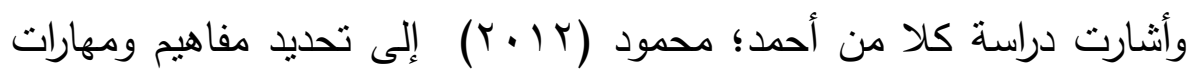
التربية المدنية اللازمة لطلاب المرحلة الثانوية(العام/التجاري)، وإعداد برنامج تعليمي مقترح في التربية المدنية وقياس فاعلية البرنامج المقترح في مساعدة الطلاب علي امتلاك مفاهيم ومهارات التربية المدنية، مما يساعدهم في الاندماج في الحياة المدنية والمشاركة الاجتماعية والسياسية، هذا وقد استخدم الباحث المنهج التجريبي ذي المجموعة الواحدة، حيث قد تكونت عينة البحث من • ^ طالب وطالبة من طلاب الصف الأول الثانوي العام والتجاري بمحافظة الفيوم، نم تقسيمه إلى مجموعتين تجريبيتين، كما قام الباحث بإعداد مجموعة من الأدوات تمنتلت في: قائمة بمفاهيم ومهارات التربية المدنية اللازم نوافرها لدى طلاب الأول الثانوي، كما قام الباحث بإعداد برنامج مقترح في التربية المدنية بناءً على هذه القائمة وتطبيقها، واختبار (تحصيلي/مواقف أدائية)، وقد أظهرت النتائج فاعلية البرنامج المقترح في تتمية مفاهيم ومهارات التربية المدنية لدى طلاب الصف الأول الثانوي (العام/التجاري). وفيما يتعلق بالمحور الثانى الخاص ببعض الدراسات ذات العلاقة بمقرر

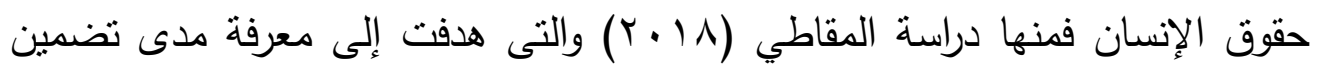
مفاهيم حقوق الإنسان في محتوى مقرر الحديث للمرحلة الثانوية لنظام المقررات بالمملكة، كما نصت عليها وثثية إعلان حقوق الإنسان لمجلس التعاون الخليجي. وتكون مجتمع الدراسة من كامل مقرر الحديث لنظام المقررات والذى يتم تدريسه في إعي 
دراسة تقويمية لمقرر حقوق الإنسان بالمرحلة الجامعية في ضوء مرتكزات التربية المدنية

د. محمد حسين على حمدان

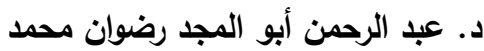

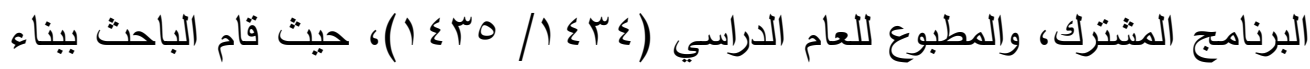
قائمة المفاهيم المحكمة في ضوء مشروع إعلان حقوق الإنسان لمجلس التعاون، وقد تم تحليل محتوى المقرر في ضوء هذه القائمة، حيث نوصلت الدراسة إلى أن مفاهيم حقوق الإنسان اللازم تضمينها في محتوى مقررات العلوم الثرعية للمرحلة الثانوية لنظام المقررات، في ضوء مشروع إعلان حقوق الإنسان بلغ (ع 9) مفهومًا، بينما بلغ مجموع مفاهيم حقوق الإنسان المتضمنة في محتوى مقرر الحديث (Y) مفهومًا،

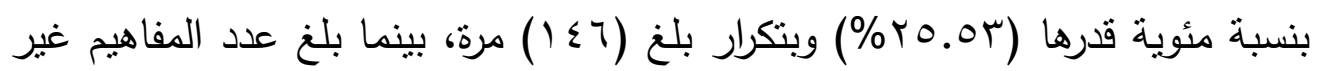

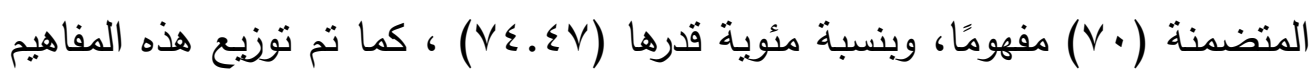
بصورة غير منوازنة وبنسب متفاوتة.

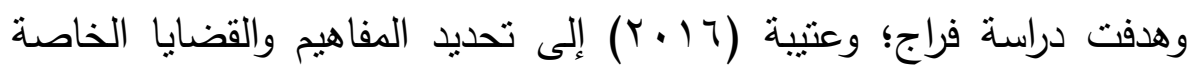
بحقوق الإنسان واللازمة لطلاب الجامعات السعودية، كما هدف إلى تشخيص واقع تدريس وتعليم تلك المفاهيم والقضايا بالجامعات السعودية، مع تقديم تصور مقترح لتدريس وتعليم حقوق الإنسان، واعتمد البحث على المنهج الوصفي المسحي، واستخدم

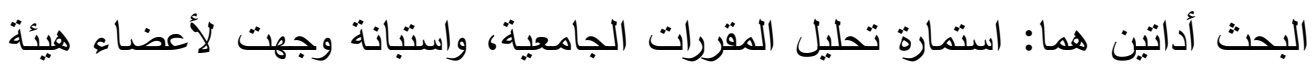
التدريس بمجموع (ITIM) عضو هيئة تدريس بجامعتي أم القري والقصيم، وكان من أبرز النتائج التي توصل إلبها البحث أن مفاهيم وقضايا حقوق الإنسان قليلة في محتوى المقررات الجامعية، كما جاء الاهتمام بها في أهداف المقرر والأثشطة ومصادر التعلم وطرق التدريس وأساليب التقويم بشكل محدود، وقدم البحث نصورًا مقترحًا لتدريس وتعليم مقرر حقوق الانسان وفق المدخل المستقل لجميع برامج وكليات الجامعات السعودية.

بينما سعت دراسة خيري (r ا • r) إلى بناء مقرر في حقوق الإنسان لطلاب المدارس الثانويـة التجاريـة وقياس أثره علي تتمية وإكساب الطـلاب للمفاهيم والقضـايا

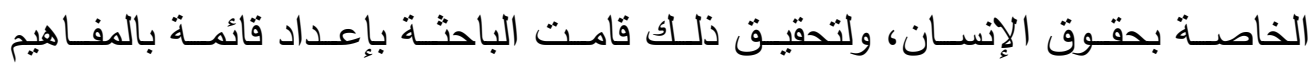
والموضـوعات المقترح تضـمينها بمقرر حقوق الإنسـان في ضـوء المعيـار الذى تم 
دراسة تقويمية لمقرر حقوق الإنسان بالمرحلة الجامعية في ضوء مرتكزات التربية المدنية

د. محمد حسين على حمدان

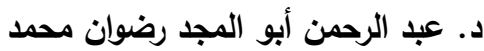

التوصل إليه، حيث تضمنت القائمة 1 ا مفهوم رئيس يندرج تحته بـ مفهوم فرعي،

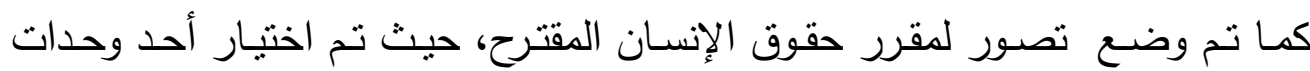
التصور المقترح وصياغتها تفصيليًا، كما تم إعداد اختبار تحصيلي للوحدة، وتطبيقه إنها

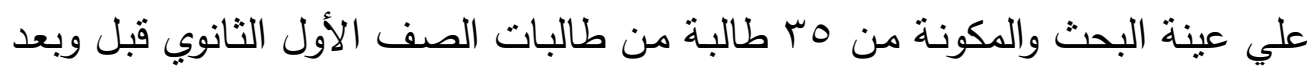
تدريس الوحدة المقترحة، حيث أظهرت النتائج وجود فروق ذات دلاله إحصـائية في

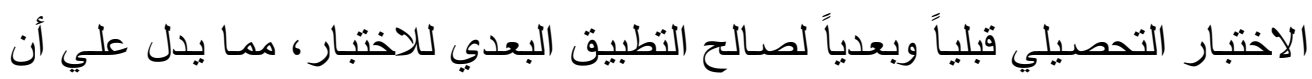
المقرر المقترح لحقوق الإنسـان يتمتع بحجم تأثنير كبير في تتميـة وإكساب مفاهيم وقضايا حقوق الإنسان لطلاب المدارس الثانوية التجارية.

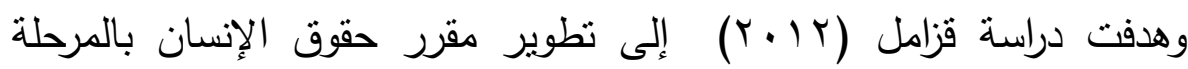
الجامعية في ضوء طبيعة الدراسة بكلية التربية، ولتحقيق ذلك تم استخدام المنهج الوصفي التجريبي، حيث تم تحديد الأبعاد التي تتفق مع طبيعة الدراسة بكليات التربية من خلال الدستور المصري، كما قدت الدراسة نقدًا لمقرر حقوق الإنسان للمرحلة الجامعية بجامعة قناة السويس، بهدف التعرف على مرجعية حقوق الإنسان في المقرر، الإنسان وقياس المحلية والعالمية في مجال حقوق الإنسان، حيث أظهر التحليل سيادة المرجعية

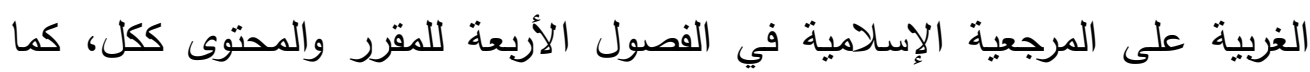
أظهرت نتائج الدراسة أن جميع أفراد البحث لم يصلوا إلى مستوى التمكن من المفاهيم والمصطلحات الخاصة بحقوق الإنسان، لذا فقد قدم البحث تصورًا لمقرر مطور لحقوق الإنسان للمرحلة الجامعية في ضوء الأبعاد التي تقوم عليها طبيعة الدراسة بكليات التربية متضمنًا البعد الإسلامي والبعد العالمي والبعد المحلى، كما نم بناء اختبار معرفي لقياس أثز وحدة من وحدات المقرر المقترح علي تقويم الجانب المعرفي والمفاهيم المتضمنة، حيث أظهرت النتائج تفوق مجموعة البحث في التقويم البعدي في وهي التعرف علي حقوق الإنسان والمفاهيم والمصطلحات المنضمنة في هذه في الوحدة، كما أوصى البحث بضرورة ثقديم حقوق الإنسان من خلال القرآن الكريم ثم الدستور المصري، وأن يتم توزيع دراسة هذه الحقوق علي سنوات الدراسة الجامعية. 
دراسة تقويمية لمقرر حقوق الإنسان بالمرحلة الجامعية في ضوء مرتكزات التربية المدنية

د. محمد حسين على حمدان

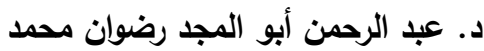

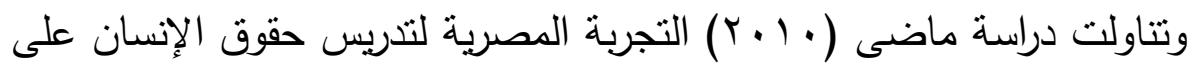

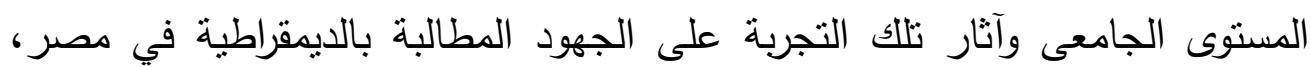
وذللك من خلال الوضع الحالى لتدريس مقررات حقوق الإنسان في بعض الجامعات المصري، وما حققته تلك التجربة من نتائج فعلية على العملية التعليمية وعلى الحركة السياسية المطالبة بالديمقراطية في مصر ، وقد أثنارت نتائج الدراسة إلى أن هناك كثيرًا من الاهتمام بتدريس حقوق حقوق لإنسان على المستوى الجامعى والبحث في القضايا

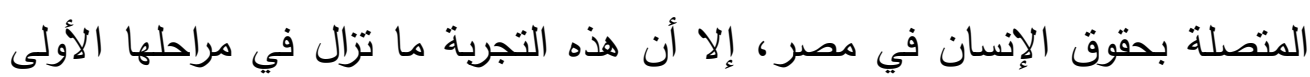
وتحتاج إلى كثثر من الجهد لنطويرها.

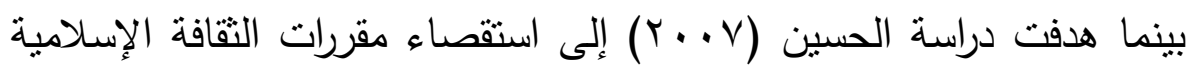

في الجامعات السعودية وكلياتها المدنية والعسكرية، حيث استخدم الباحث المنهجين الوصفي والنقدي، بهدف التعرف على ما تضدنته هذه المقررات من مقرر حقوق

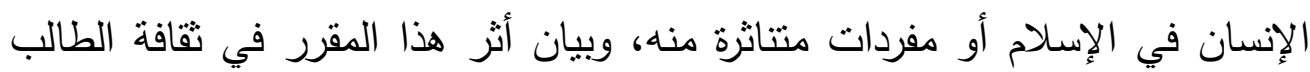
الجامعي، حيث كثفت النتائج أن هناك جامعات أفردت هذا المقرر بصورة خاصة، الإنة وهناك جامعات أخرى ضمنته في المنهج بشكل جزئي داخل المقررات بصورة عامة، وهناك كليات لم تتطرق تماما إلى قضايا حقوق الإنسان في مقرراتها الدراسية، لذا فقد قام الباحث بوضع توصيف مقترح لمقرر حقوق الإنسان تحت مسمى (حقوق الإنسان في الإسلام) من أجل تزويد الطلاب بجرعة ثقافية مناسبة، نتبع مما جاء في الإسلام

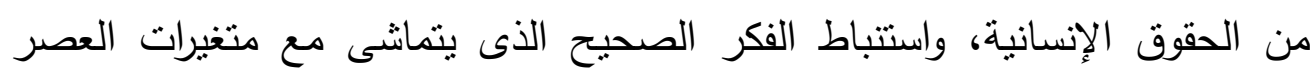
ومستجداته بكل توازن ووسطية.

وكثفت دراسة بادي (ع . †) على موضوعات الإعلان العالمي لحقوق

الإنسان التي يتضمنها كتاب التربية المدنية للصف الأول الثانوي في فرنسا، وتحديد الكم الإحصائي لهذه الموضوعات للتعرف علي الموضوعات التي يتم التركيز عليها أكثر من غيرها، حيث تكونت عينة البحث من البرنامج الرسمي لمقرر التربية المدنية

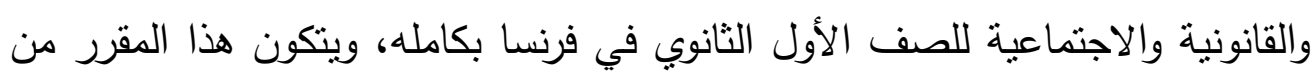


دراسة تقويمية لمقرر حقوق الإنسان بالمرحلة الجامعية في ضوء مرتكزات التربية المدنية

د. محمد حسين على حمدان

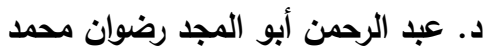

مجموعة من المفاهيم المدنية والقانونية والاجتماعية، ييلغ عددها (ب0) مفهومًا تتدرج تحت أربعة محاور أساسية هي: المواطنة والمدنية، المواطنة والتكامل، المواطنة

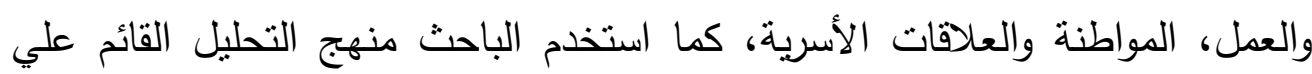
المفاهيم، حيث قام بتطبيق مجموعة من الأدوات تمثلت في (بنود الإعلان العالمي لحقوق الإنسان، مصنف ليا ليفين الذى يتضمن تقسيم بنود الإعلان العالمي لحقوق

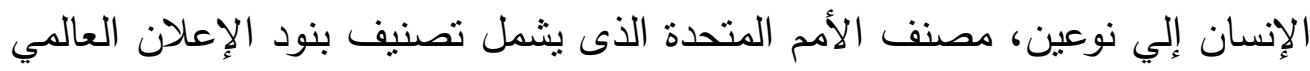
لحقوق الإنسان في (YT) موضوعًا أساسيًا)، وقد أظهرت النتائج أن كتاب التربية المدنية تضمن معظم بنود الإعلان العالمي لحقوق الإنسان، وقد تم إدراج هذه البنود

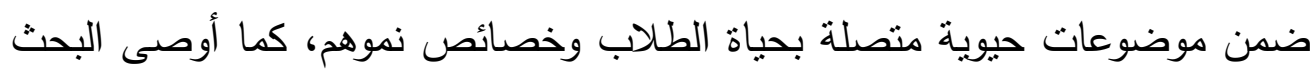
بضرورة الاهتمام بتضمين حقوق الإنسان في كتب التربية الوطنية في أب بلد علي أن يراعي في ذلك اهتمامات التلاميذ ومستوياتهم الدراسية.

وفي ضوء العرض السابق للبحوث والدراسات السابقة يتضح ما يلي: - قلة البحوث والدراسـات السابقة التي أجريت في المجتمع المصرى حول تقييم

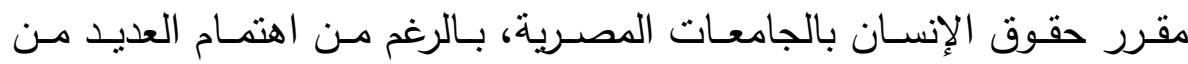

$$
\text { البحوث والمؤتمرات بمجال حقوق الإنسان. }
$$

- - اتفقت معظم البحوث والدراسات السابقة على أهمية التربية المدنية سواء على الإنى مستوى الفرد أو المجتمع وكذلك أهمية تدريس مقرر حقوق الإنسـان بالمراحل التعليميـة، واختلفت في تتاولها للتربيـة المدنية، فبينما ركزت بعض الدراسـات على برامج التربية المدنية وأخري على تحليل مقررات التربية المدنية، وهناك دراسات ربطت بين متغير التربية المدنية ومنهج التربية الأسرية. - اختلف البحث الحالي عن الدراسات السابقة بشكل كلي في تركيزه على مرتكزات التربية المدنية ومستوي تضمينها بمقرر حقوق الإنسان بجامعة جنوب الوادي. - استفاد البحث الحالي بشكل كبير من الدراسات والبحوث السابقة في تقديم إطار نظري يتتاسب مع موضوع البحث، والتعرف على أهمية ومرتكزات 
دراسة تقويمية لمقرر حقوق الإنسان بالمرحلة الجامعية في ضوء مرتكزات التربية المدنية

د. محمد حسين على حمدان

د. عبد الرحمن أبو المجد رضوان محمد لديد

التربية المدنية، وبناء استمارة تحليل المحتوي للتعرف على مستوى تضمينها

بمقرر حقوق الإنسان.

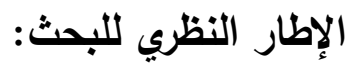

تم تقسيم الاطار النظري لمحورين رئيسين هما: التربية المدنية وتحليل محتوي مقرر حقوق الإنسان، ويمكن عرض ذللك تفصيليًا على النحو التالي:

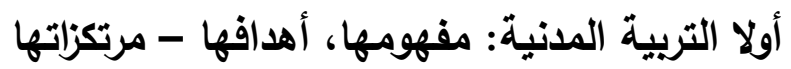
- مفهوم التربية المدنية

حظي مفهوم التزبية المدنية باهتمام العديد من الباحثين في المجالات المختلفة، ولقد نم تتاوله من قبلهم من عدة زوايا تبعا لاتجاهاتهم وتخصصاتهم ومجال دراستهم. حيث تعرف التربية المدنية من خلال القواميس والمعاجم بأنها مفهوم واسع مانح ضدن مجالات التربية الحديثة فيعرفها المعجم الموسوعى لمصطلحات التربية بأنها "باب من أبواب التربية المدنية يتتاول شئون المجتمع عامة ومشكلاته ويهدف إلى تكوين رأي عام مستتير عن طريق بث المعلومات الاجتماعية الضرورية في مختلف

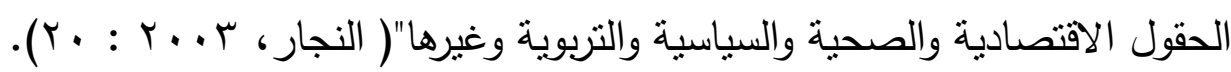
بينما عرفها قاموس موسوعة ستتافورد للفلسفة في تعريفه الواسع بأن التربية المدنية تعنى "جميع العمليات التي تؤثز على معتقدات الناس، والتزاماتهم، وقدراتهم، بـه

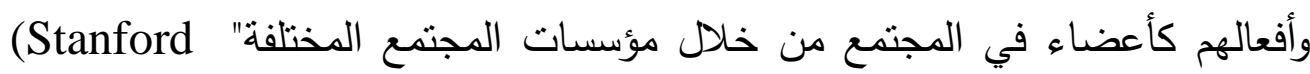
.Encyclopedia of Philosophy,2007) وهناك العديد من الباحثين يرون أن التربية المدنية فرع من فروع التربية لتكوين جيل مستتير سياسيا حيث يعرف Ross (2012:8) التربية المدنية بأنها جانب التعليم الذي يتعامل مع العلاقة بين الفرد والمجتمع السياسي، وبين الذات والآخرين. ويشير Patrick (2002: 2) بأنها التربية اللازمة لكى يصبح الأفراد مواطنين ولين فاعلين في نظام ديمقراطي دستوري من خلال إكسابهم مجموعة المعارف والمهارات 
دراسة تقويمية لمقرر حقوق الإنسان بالمرحلة الجامعية في ضوء مرتكزات التربية المدنية

د. محمد حسين على حمدان

د. عبد الرحمن أبو المجد رضوان محمد لديد

والاتجاهات اللازمة لذلك، ومنها الحقوق والواجبات والحريات الأساسية، ومهارات صنع القرار حول القضايا العامة.

ويري البعض أن التربية المدنية تمنل عملية التنشئة الاجتماعية والسياسية القائمة على أساس علمى، والتى تهدف إلى إكساب الأفراد وعيًا سياسيًا واجتماعيًا يركز

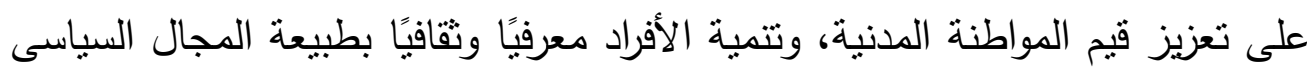
الذى يعيشون فيه وكيفية تفعيل أدوارهم وممارساتهم. فهذا المفهوم يركز على البعد التربوي والتقافى والذى من خلاله يتم إكساب الأفراد نقافة تتمحور حول طبيعة المواطنة المرتكزة على منظومة الحقوق المدنية والسياسية ( أبو النور، عبد الفتاح؛ وعبد الفتاح،

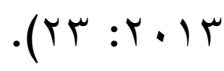

Center for Civic Education ويؤكد مركز التربية المدنية الأمريكي أن التربية المدنية تمثل الأساس في بناء المجتمع الديموقر اطي وتعنى الإعداد للحكم

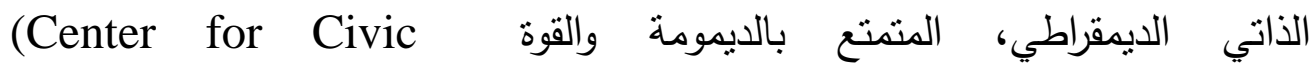
.Education,2010:2)

كما توصف التربية المدنية بأنها نظام تعلُّم يكرس مبادئ الحياة المدنية منل احترام القانون والنظام والمسؤولية والتفكير النقدي والموضوعية والتتسيق في الأنشطة

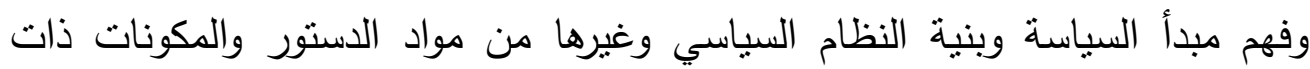
الصلة (Shabani,2013).

وهناك من الباحثين من يركز في تعريفه على محتوي التربية المدنية بمرتكزاتها الثلاثة المتداخلة فيما بينها المعرفية والمهارية والوجدانية حيث يشير بدران (9 . . ب : • ب) بأنها: تلك العملية التى تستهدف تزويد الأفراد بالمعارف والمفاهيم والمهارات

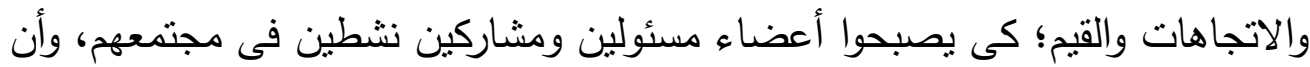
يكونوا على وعى تام بحقوقهم، وإدراك كامل بواجباتهم، كما تتمى عندهم قيم الولاء والانتماء للوطن، وتتمى لديهم أيضًا الاتجاهات الإيجابية نحو ممارسة الديمقراطية واحترام القانون. 
دراسة تقويمية لمقرر حقوق الإنسان بالمرحلة الجامعية في ضوء مرتكزات التربية المدنية د. محمد حسين على حمدان د. عبد الرحمن أبو المجد رضوان محمد

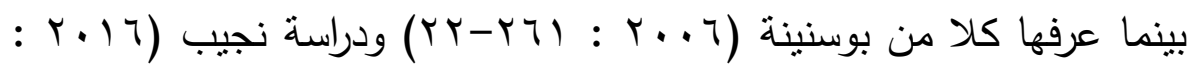
rr) بأنها مشروع عام لتمكين الثباب من الإمام بالمعارف والقيم والمهارات الأساسية

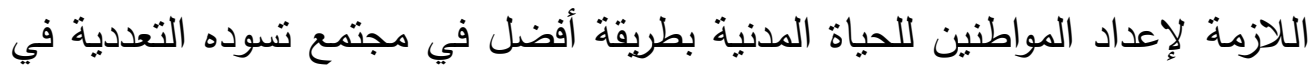
القيم والاتجاهات الاجتماعية والسياسية والدينية في أساليب الحياة، وفهر ركائز المجتمع المعاصر منت: دولة القانون وحقوق المواطنة والديمقراطية، وإدراك معنى وأهمية قيم العيش المشترك على المستوبين الوطنى والعالمي. ويثير أبو الكاس (10 ( + ب). بأنها عملية مسئولة عن تزويد الفرد بالمفاهيم والمهارات والمعارف والقيم لتعديل سلوكه، وتيسير علاقاته مع نفسه فضلاً عن نيسير علاقاته مع الآخرين ويمكن أن تسهم في بناء مجتمع تسوده الديمقراطية. وعلى الرغم من اختلاف التعريفات السابقة فيما بينها إلا أنها اتفقت جميعًا على أن التربية المدنية تتضمن إكساب الأفراد معلومات ومهارات وقيم تؤهلهم للعيش التهن في مجتمع معاصر تسوده قيم الانتماء والولاء من خلال ممارسة الأفراد ووعيهم بقيم الديمقراطية واحترام القانون واحترام حقوق الإنسان. - أهداف التربية المدنية:

تسهم التربية المدنية في بناء الفرد المتكامل والمنوازن فى جوانب شخصيته اجتماعيًا وفكريًا وروحيًا وإنسانيًا، والواعي بحقوقه وواجباته، والمؤمن بحقوق الإنسان ومبادئ الحرية والعدالة والمساواة. وتتعدد أهداف التربية المدنية في المجتمع المصري كما ذكر قاسم

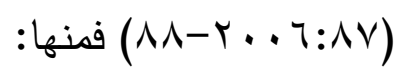

- التعرف على المفاهيم الأساسية للايمقراطية. - دعم المواطنة الديمقراطية الواعية والفعالة والمسئولة على أساس من الحقوق والمسئوليات.

- تتمية المسئولية الاجتماعية والأخلاقية والانخراط المجتمعي والنزوع الطوعي. - تتمية الفهم بأدوار المواطنين المتتوعة في النظم الديمقراطية. 
دراسة تقويمية لمقرر حقوق الإنسان بالمرحلة الجامعية في ضوء مرتكزات التربية المدنية د. محمد حسين على حمدان د. عبد الرحمن أبو المجد رضوان محمد لديد

- دعم التعددية التقافية والانخراط والاسهام في الحضارة العالمية كمواطن عالمي. - تتمية فهم النظام السياسي بمؤسساته المختلفة وتجسيده للايمقراطية.

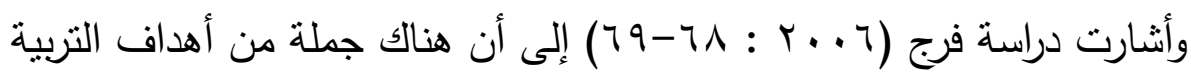
المدنية منها: - - إكساب الطلاب القيم المدنية والحضارية ومنها الحرية وتحمل المسئولية والواجب الوطنى.

- تتمية روح المواطنة المدنية وتعريف الطالب بمفهوم المواطنة والحقوق والواجبات. - تتميـة مهارات التقكير العلمي والناقد وتتميـة مهارات الحـوار والتقـاوض وصـنع

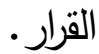
- - اكتساب الوعى القانوني وقدر كاف من المعلومات والمعارف حول الدولة وطبيعة المجتمع. - اكسـاب الطـلاب وعيًا اجتماعيًا بمجمل التيـارات الفكريـة والثقافيـة والسياسية السائدة في المجتمع والعالم وكيفية التعامل معها.

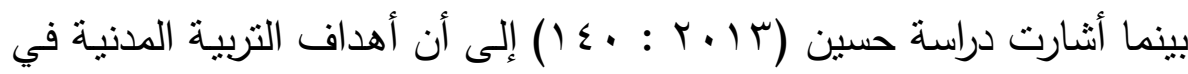
المجتمع المصري تتمثل في جوانب عدة منها: بنـاء المواطن الذى تقع عليه أعباء النهوض الحضاري وبناء الأوطان، تزويد الأفراد بالمعرفة حول حقوق الإنسان والتقافة القانونية وإتاحة الفرصة لممارسة تلك الحقوق في ظل المتغيرات المجتمعيـة، التعريف بكيفية المشاركة المجتمعية واكتساب المهارات الضرورية من أجل المواطنة الصالحة، الحفاظ على الحياة الديمقراطية، وتتميـة الثـعور بالانتماء، وتتمية المشـاركة السياسية لاى المواطنين وتدريبهم على المشاركة في صنع القرار، وتتميـة الرغبـة والقدرة على بلى المشاركة في صنع القرار المحلى والوطنى، من خلال الاشتراك في مؤسسات المجتمع المدنى. 
دراسة تقويمية لمقرر حقوق الإنسان بالمرحلة الجامعية في ضوء مرتكزات التربية المدنية د. محمد حسين على حمدان د. عبد الرحمن أبو المجد رضوان محمد لديد

وتؤكد العديد من الدراسات أن هنالك جملة من الأهداف تسعي التربية المدنية إلى تحقيقها وتتمثل في:

- تعزيز وعي الطـلاب بطبيعـة الحيـاة المدنيـة ومبـادئ تتظيم الحيـاة السياسية والديمقراطية. - تكوبن قاعدة ثقافيـة مشتركة في توجهاتها وقيمها تعلي مـن شـأن التماسـك الاجتماعي. - تكوبن الفرد الواعى بقيم وثقافة المواطنة وواجباتها وأهمية المشاركة المجتمعية والسياسية الفاعلة. - تميـة مهارات التفكير العلمي والعقلانـى ومناقتـة القضايا ومعالجة المشكلات واتخاذ القرارات والعمل التعاونى والتفاوض مع الآخرين. - تتمية حساسية متتامية لدى الطلاب بالأبعاد العالمية والإيجابية لقيم التعاون ولهين الدولى والسلام العالمى والعبش مع الآخر . - تعزيز ثقافة السلام القائم على العدل وعلى احترام حقوق وثقافات الآخرين. - تشكيل مجتمع مدني يعرف فيه كل فرد ما لديه من حقوق وما عليه من واجبات. - توضح علاقة الفرد بالآخرين في المجتمع وعلاقته مـع الحكومات (بوسنينة، ج . . ؟ T

فى ضوء العرض السابق يتضح أن للتربية المدنية العديد من الأهداف منها: توعية الفرد بحقوقه وواجباته ومعرفة مبادئ الديمقراطية وحقوق الإنسان، ورفع مستوى الوعى الاجتماعي والسياسي، وتتمية مهارات التفكير العلمي والعقلاني ومناقثة القضايا

$$
\text { التي تهم المجتمع واتخاذ قرارات سليمة نحوها. }
$$

تعددت تصنيفات الباحثين حول التربية المدنية إلا أنهم جميعًا يرون أنها تسهر

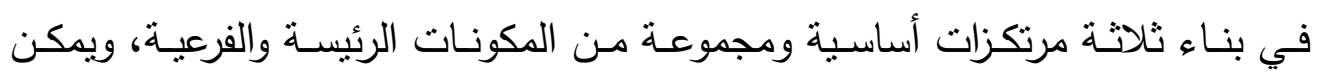
عرض ذلك على النحو التالي: 
دراسة تقويمية لمقرر حقوق الإنسان بالمرحلة الجامعية في ضوء مرتكزات التربية المدنية د. محمد حسين على حمدان د. عبد الرحمن أبو المجد رضوان محمد لعدي

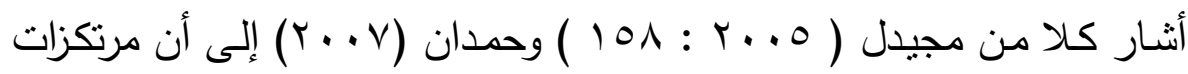
ودعـائم التربيـة المدنيـة تشـمل المعـارف المدنيـة والمهـارات المدنيـة والفضـائل المدنيـة وتقصيلاً على النحو التالي:

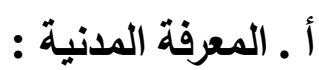

تتكون المعرفة المدنية من أفكار جوهرية، ومعلومات يجب على المتعلمين معرفتها، واستخدامها لتصبح مؤثرة في سلوك مواطن الديمقراطية، وتتضمن المعرفة المدنية بصورة عامـة مبادئ النظريـة الديمقراطية، وعمل الحكم الديمقراطي، وتصرفات المواطنة الديمقراطية.

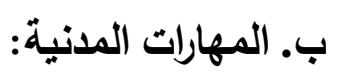

هي العمليات المعرفية التي تمكن المتعلم من فهم وشرح ومقارنة وتقييم مبادئ وممارسات الحكومة، كما تتضمن المهارات التشاركية التي تتطوي على أفعال من قبل المواطنين لرصد السياسـات العامـة وحسم القضـايا العامـة، ونتشمل المهارات التشـاركية استخدام المواطن للمعرفة لكى يفكر ويتصرف بكفاءة ومسئولية تجاه التحديات المستمرة للحكم والمواطنة الديمقراطية. ج • الفضائل / القيم المدنية: المرتكز الأساسي الثالث في التربية المدنية وتعني فهم السمات الضرورية للثخصية من أجل الحفاظ على الحكم الديمقراطي وتجويده وتعزيز قيم المواطنة، ويتمثل

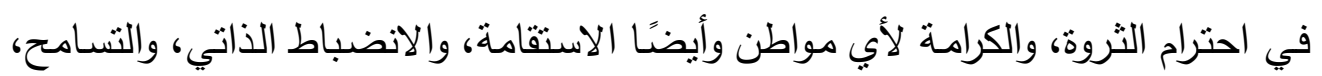
وحب الوطن.

وتعد دراسـة المعـايير القوميـة للتزبيـة المدنيـة والحكوميـة والتي أجراهـا مركز

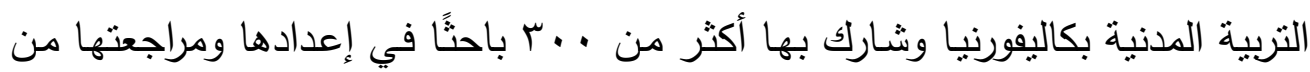

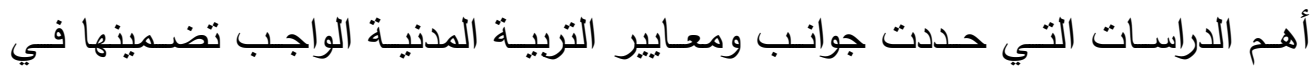
المقررات والمناهج وهى، المعرفة المدنية: ويتعلق هذا الجانب بالمحتوى والمعارف التي

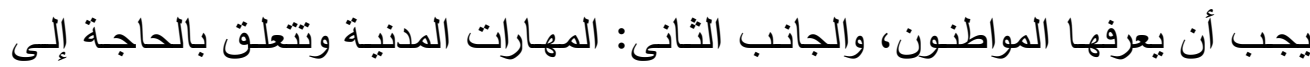


دراسة تقويمية لمقرر حقوق الإنسان بالمرحلة الجامعية في ضوء مرتكزات التربية المدنية د. محمد حسين على حمدان د. عبد الرحمن أبو المجد رضوان محمد لديد

اكتساب مهارات عقلية ومهارات المشـاركة الإيجابية للأفراد، والجانب الثالث: الميول المدنية والتي تمثل الجانب الوجداني بما فيه من قيم وميول واتجاهات تسهم في توجيه ومشاركة الأفراد في بناء المجتمع الديمقراطي ,2010)

ويشير Doganay (2012) إلى أن مرتكزات التربية المدنية تتمثل في: أ- المعارف المدنية، وتثثمل: معرفة سياسية: ومنها النظام السياسى والقانوني، المفهوم والمبادئ والمؤسسات الديمقراطيـة، مفهوم المواطنة الديمقراطيـة وحقوق المواطنين ومسؤولياتهم بمـا فيها حقوق الإنسان، اتخاذ القرارات السياسية على المستوى المحلي والدولي، القضايا السياسية الراهنة. معرفـة اجتماعيـة: ومنهـا العلاقـات الاجتماعيـة، الحقوق الاجتماعيـة، العهـل لروفل

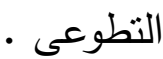

معرفة ثقافية: ومنها التاريخ والتراث الثقافى داخل البلد الواحد، معرفة بمختلف الثقافات المحلية والإقليمية والوطنية والعالمية. معرفة اقتصادية: ومنها الحقوق الاقتصادية، المسائل المالية المرتبطة بمحو ولهو الأمية الثقافية. ب- المهارات المدنية، وتثثمل: - الميه

مهارات التفكير النقدي: ومنها التوصل الى قرار متوازن، أو وجهة نظر مبنية على دراسـة نقديـة مـن المعلومـات والمنطـق، الـدفاع عـن الموقف الذي تـم

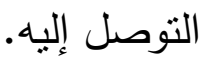
مهارات حل المشاكل وصنع القرار ومنها التفكير الإبداعي، مهارات البحث ، مهارات التواصل. مهارات المشـاركة: ومنها التأثير على السياسات والقرارات من خـل العمل مـع الآخـرين المشـاركة فـى القـرارات السـلمية، المشـاركة الطوعيـة في مجـال المنظمات المدنية. 
دراسة تقويمية لمقرر حقوق الإنسان بالمرحلة الجامعية في ضوء مرتكزات التربية المدنية

د. محمد حسين على حمدان

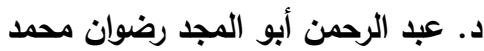

ج - الفضائل المدنية، وتثمل:

القبـم: ومنهـا قبـول سـيادة القانون، احترام حقوق وكرامـة الانسـان، العدالـة

الاجتماعيـة، والمســاواة والمعاملــة بالمثنل مـن المـواطنين، رفض التحيـز

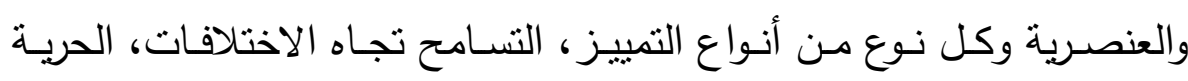

والنزاهة.

المواقف وتتمل: الانخراط في العملية السياسية، الثقة في المبادئ الديمقراطية،

الثعور بالمسئولية لاتخاذ القرارات الخاصة، الالتزام بالسلام.

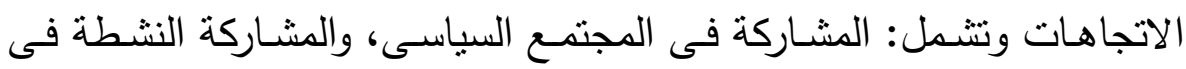

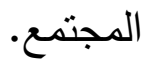

وهذا وتؤكد العديــ مـن الدراسـات على أن التربيـة المدنيـة تتمثل في ثلاتـة مرتكزات أو نطاقات أو أبعاد وهي: الوعي المدني، والميل المدني، والمهارات المدنية، ويمكن عرض ذللك تقصيلاً كالتالي: أ) الوعي المدني:

ويشــير إلـى المعرفـة المدنيـة أو مجموعـة مـن المعلومـات والمعـارف والفهـم

المدني، مثل: معرفة هيكل الحكومة ووظيفتها، معرفة وجهات نظر الأحزاب السياسية الرئيسة في البلاد، الوعي بالأحداث التي تحدث في المجتمع، والوعي بالقوانين واللوائح الاجتماعية والوعي بالحقوق الثخصية والدولية. ب) الموقف أو الميل المدني:

حيث يستتد إلى البعد العـاطفي ومن ثم فإن التربيـة المدنيـة هي المسـاءلة

الاجتماعية للحفاظ على حكم وطنى قوي وتتمثل في مجموعة من المؤشرات منها: وجود شعور وطني، وجود روح التقدير نحو التراث الثقافي والهوية الوطنية والدينية، بعد

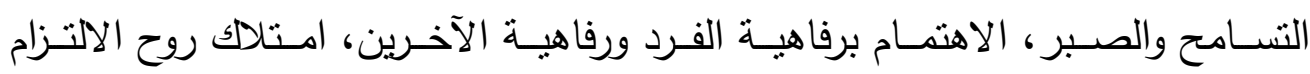
بالقانون، وجود شعور لقبول النقد، الاعتراف بالتتوع والتعددية في المجتمع وتحترمهم. 
دراسة تقويمية لمقرر حقوق الإنسان بالمرحلة الجامعية في ضوء مرتكزات التربية المدنية

د. محمد حسين على حمدان

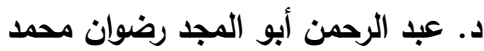

\section{ج) المهارات المدنية أو القدرة المدنية:}

ترتبط المهارات المدنية بمجال أداء سلوك الطلاب، بحيث يجب عليهم توظيف

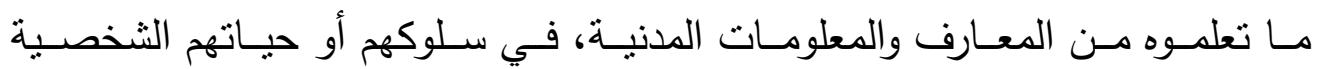
والاجتماعية، وتتمل مجموعة من المهارات والقدرات والإمكانات ، التي يحتاجها كل واحد منهم للعيش في مجتمـع يعيش فيه، ومكوناته على النحو التالي: القدرة على المشاركة مع الآخرين، والقدرة على تتفيذ الوظائف دون الاعتماد على الآخرين، والقدرة

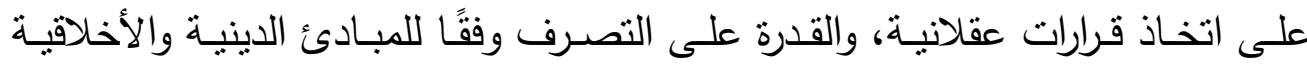

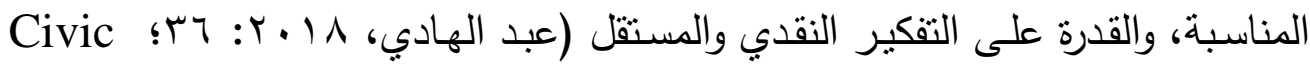
Shabani ,2013:58-59) (Mission of Schools report 2003 :16 .(Parker,1996:186؛

في ضـوء مـا سبق يتضـح أن هنـاك ثلاثتة مرتكزات أساسية للتربيـة المدنيـة، وهى: المرتكز المعرفي والمرتكز المهاري والمرتكز القيمي، وبطبيعـة الحال لا ينجح الفعل التربوى فى تحقيق أهدافه وغرس قيمهـ واتجاهاته فى حال افتقاد هذه الجوانب شـروط الاتسـاق والتكامـل والتـرابط، ومـن ثم لا تنجح أيـة جهود تركز على إكسـاب

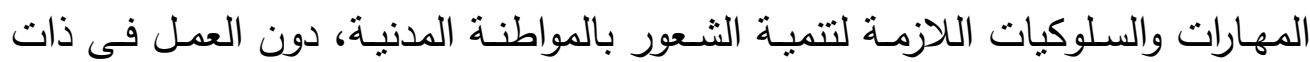
الوقت على بعدى المعارف والقيم. ثانيا: تحليل المحتوى، مفهومه ، أهميته، خطواته بـه يعد تحليل المحتوى بغرض تقويم المقررات الدراسية من الإجراءات المهمة التى ينبغى القيام بها بثكل مستمر ، حتى يمكن للنظام التعليمي مواجهة المسئوليات الملقاة على عاتقه، وحتى يتمكن من مواجهة التغيرات الهائلة التي تواجهه، لبناء أجيال يمكنها التكيف بسهولة مع متغيرات العصر، وهذا الأمر جعل المتخصصين في مجال التربية يقومون كل فترة بتحليل الكتب والمقررات الدراسية؛ بهدف إعطاء وصف دقيق لما يتضمنه المقرر الدراسي من حقائق ومفاهيم وقيم ومهارات، والكثف عن مواطن القوة 
دراسة تقويمية لمقرر حقوق الإنسان بالمرحلة الجامعية في ضوء مرتكزات التربية المدنية د. محمد حسين على حمدان د. عبد الرحمن أبو المجد رضوان محمد لديد

والضعف فيه، مع تقديم المبادئ الأساسية للتصحيح والتعديل، بما يسهم في تطويره وتحقيق أهدافه.

- - مفهوم تحليل المحتوى

التحليل لغة هو " إرجاع الثـيء إلى عناصره، فحلل الثيء إلى عناصره أى

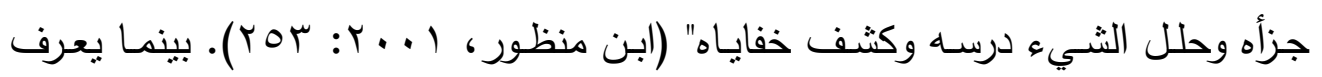
التحليل اصطلاحًا بأنه " بيان وتقصيل وتجزئة الأشياء الكلية، بإرجاعها إلى عناصرها

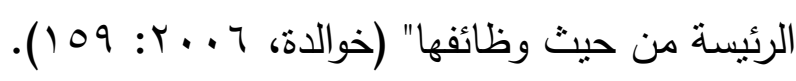
ويعرف المحتوى اصطلاحًا بأنه "جملة المعارف والمعلومات المنظمة على نحو معين والتى تتضمنها خبرات ونشاطات المقرر لتحقيق الأهداف التربوية" (صحراوي، . (Ar: $:$. . s

وظهر أسلوب تحليل المحتوي كأسلوب من أسـاليب البحث العلمى بدايـة في مجال العلوم الاتصـالية وتجاوزه بعد ذلك إلى العلوم الإنسانية، حيث كانت غايـة هذا

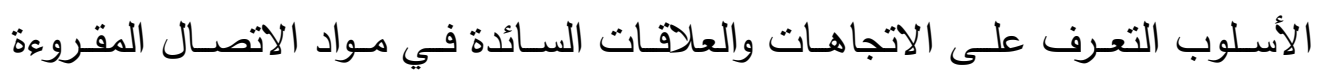

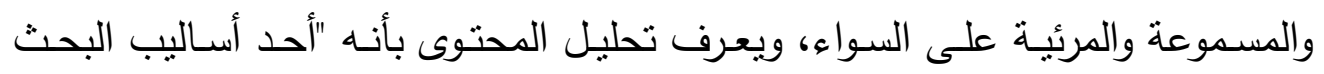
العلمى، التي تهدف إلى الوصف الموضوعي، والمنظم ، والكمي لمادة أو أكثر من ون

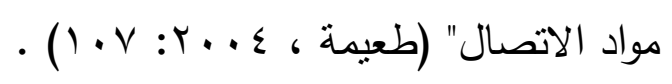
كما يعرف تحليل المحتوي بأنه "أسلوب مـن أسـاليب البحث العلمسى يندرج

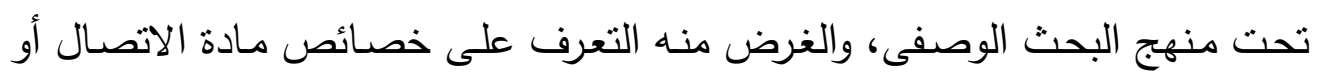
الكتب الدراسية، ووصف هذه الخصـائص وصفًا كميًا معبرًا عنسه برموز كميـة، إلى والى جانب ما يتم الحصول عليه من نتائج بأساليب أخرى تكون مؤشرًا تحدد اتجاه التطوير

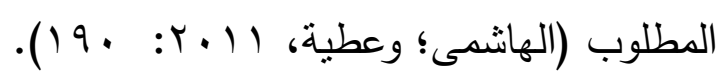

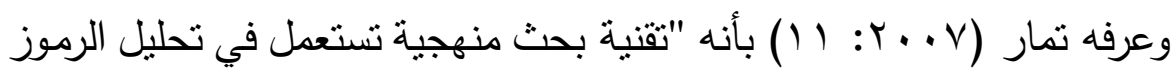
اللغوية وغير اللغوية الظاهرة دون الباطنة، الساكنة منها والمتحركة، كلها ومضمونها، والتي تشكل في مجملها بناء مضمون صريح وهادف". 
دراسة تقويمية لمقرر حقوق الإنسان بالمرحلة الجامعية في ضوء مرتكزات التربية المدنية

د. محمد حسين على حمدان

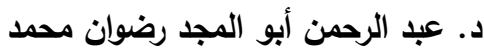

يتضـح من التعريفات السـابقة أن وصف تحليل المحتوى بأنه أحد أسـاليب البحث

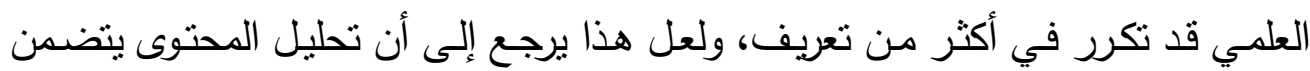

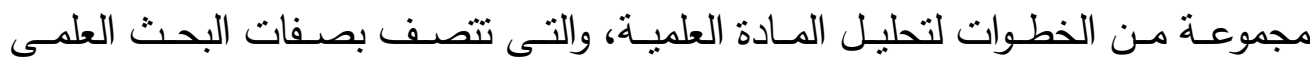
المنهجي من موضوعية وحياد وانتظام وقابلية لتعميم النتائج التى ينم التوصل إليها. وعادة فإن تحليل المحتوى لا يجرى بغرض الحصر الكمى لوحدة التحليل فقط، ولكن يتعداه لمحاولة تحقيق هدف معين، كما أنه يقتصر فقط على وصف الظاهرة وما قاله الإنسان أو كتبه صراحة فقط دون اللجوء إلى تأويله، وهو ما يشار إليه بكلمتي (وصفًا كميًا)، بالإضـافة إلى ذللك يعتمد تحليل المحتوى على الرصد التكرارى المنظم لوحدة التحليل المختارة، سواء أكانت كلمة أو موضوع أو مفردة أو شخصية أو وحدة أو الو لوري زمن، وأخيرًا لم يحدد تحليل المحتوى أسلوب اتصـال معين دون غيره، فيمكن أن بطبق تحليل المحتوى على أى مادة اتصال مكتوبة، أو مصورة، أو غيرها من مواد الاتصال

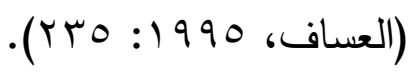

فالهدف الأساسي من تحليل محتوى المقررات الدراسية هو العمل على تطوير المواد التعليميـة ومن بينها الكتاب الدراسـي الذى يتصدى لتحليل محتواه، وهنـا يبدوا

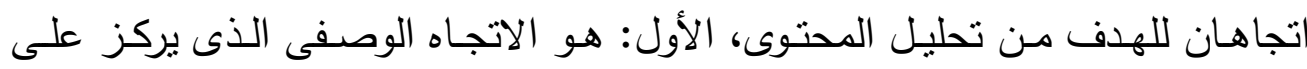
الجوانب الوصفية كمية كانت أو كيفية حيث يتت رصد الظاهرة دون تفسيرها، والثانى: هـو الاتجـاه الـديناميكى الذى يتجـاوز الوصـف إلى اختبـار صـحة الفـروض والتتبؤ بمتغيرات تـرتبط بمصـدر الرسـالة واتجاهـه، ومسـتقبل الرسـالة مـن حيث الآثار التى

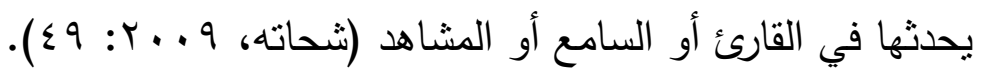
ولعل هذه الأسلوب العلمى للبحث يتميز عن غيره بمجموعة من المميزات، منها أن جمع المعلومات ودراستها دون الاتصال المباثر مع مصادر بشرية، يمكن أن

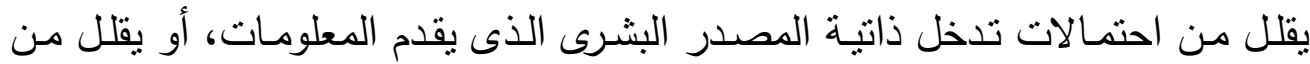
إمكانية وقوعه في أخطاء مقصودة أو غير مقصودة بسبب النسيان ، كما أن الوثائق دائمًا متاحسة أمسام الباحث ويستطيع العودة إليها عدة مـرات لدراستها، والتأكد منهـا، 
دراسة تقويمية لمقرر حقوق الإنسان بالمرحلة الجامعية في ضوء مرتكزات التربية المدنية د. محمد حسين على حمدان د. عبد الرحمن أبو المجد رضوان محمد لديد

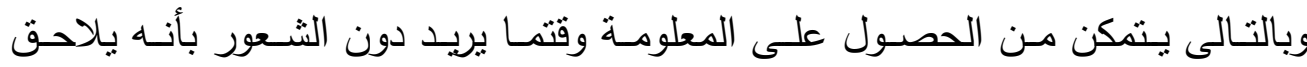

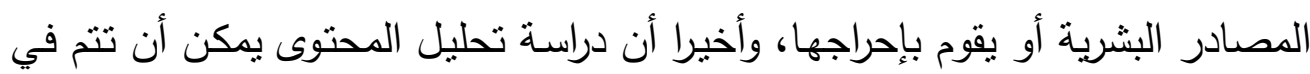

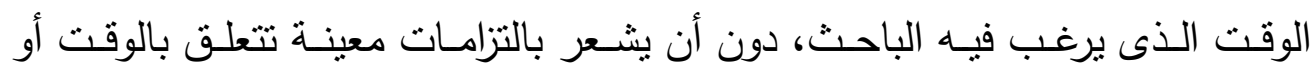

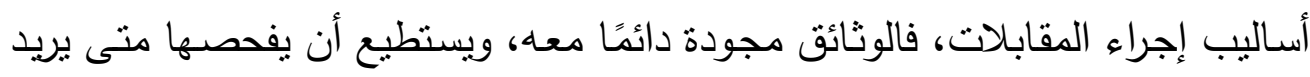

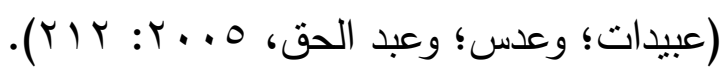
ويتضح مما سبق أن تحليل محتوى المقرر الدراسي هو عملية تهدف إلى قراءة المحتوى قراءة متأنبـة بهدف التعرف على مـا يتضــنه مـن معـارف وقيم ومهارات

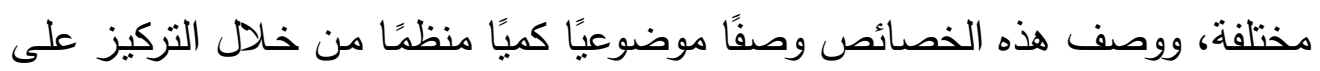
المعلومات المتضمنة في المحتوى. - أهمية تحليل المحتوى

بصفة عامة لتحليل المحتوى أهمية كبيرة في العطلية التربوية يمكن إيجازها في: (فرج، $\cdot(r): r \cdot 11$

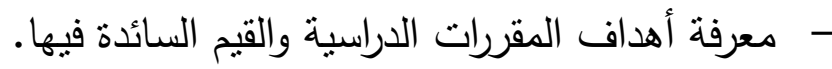
- - اكتشـاف أوجـه القوة والضـعف في الكتب الدراسبة والمـواد التعليميـة، وتقديم أساسًا لمراجعتها وتعديلها عند الحاجة. - تزويد واضعى المناهج بما ينبغي فعله من أجل تطوير المقررات.

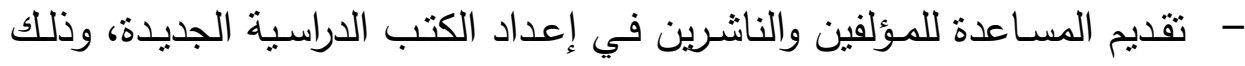
بتزويدهم بمبادئ توجيهية والإشارة إلى ما ينبغى تجنبه، وما ينبغى تضمينه.

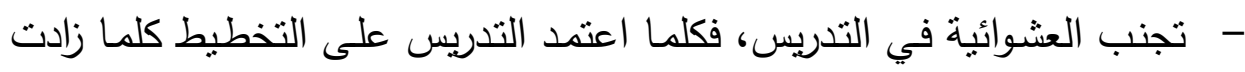
ثقة المعلم بفاعلية الأسلوب التدريسي الذى يستخدمه.

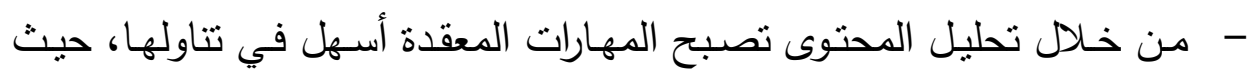
يمكن تجزئتها إلى مهارات فرعية بسيطة، وبالتالي تصبح أكثر فاعلية. 
دراسة تقويمية لمقرر حقوق الإنسان بالمرحلة الجامعية في ضوء مرتكزات التربية المدنية

د. محمد حسين على حمدان

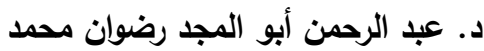

- - التعرف على المفاهيم والمعـارف والمبـادئ والحقائق المتضمنة في المحتوى التعليمى، والتعرف على المهارات الأنشطة التى تسـاعد في تتميـة المفـاهيم

$$
\text { والمعارف المتضنة في المحتوى. }
$$

- المساعدة في أن تكون عملية التدريس أكثر فاعلية بما تتضمنه من وسـائل ومواد إثرائية، والتعرف على الفرص المتاحة لتعلم أفضل. وبشكل خاص يعد تحليل المحتوى الدراسي مهما للمعلم حيث يجعله قادرًا على تتظيم المعـارف والمهارات بشكل يسـاعده على تحقيـق الأهداف المخطط لهـا، لأن العملية التدريسية تسبر وفق خطوات منظمـة، فالتحليل يوجها عمل المعلم ويفيده في تحضـير أنشطة مختلفـة تتناسب مـع عناصـر المقرر، كمـا يعطى فكرة عن نوعيـة الموضوعات والتسلسل المتبع في عرضها.

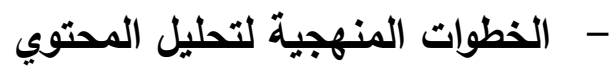
يشبه تحليل المحتوى بشكل عام غيره من طرق البحث المختلفة من حيث

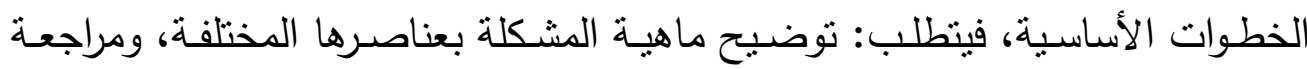
الدراسـات السـابقة، ومعرفة كيفية تصميم البحث وتحديد خطواته الإجرائية، بالإضـافة إلى ذلك تمر عملية تحليل المحتوى بمجموعة من الخطوات يمكن إجمالها في الآتي:

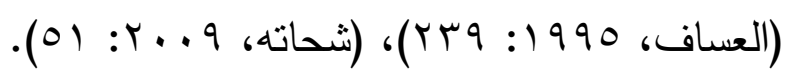

1 - تحديد مجتمع البحث الكلى، أى مواد الاتصال التى سوف يطبق عليها البحث،

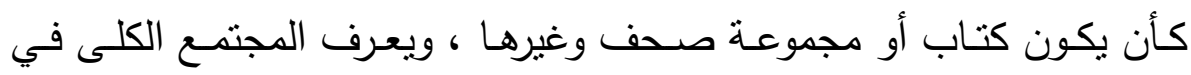
بحوث التحليل" بمجموع المصادر التى نشر فيها المحتوى المراد دراسته خلال

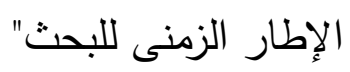

r - جمع وتحليل المعلومات وذللك من خلال الخطوات التالية: أ. تصنيف المحتويات المبحوثة: وذللك طبقًا لنظام تصنيف يتلائم مع مشكلة البحث

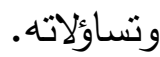


دراسة تقويمية لمقرر حقوق الإنسان بالمرحلة الجامعية في ضوء مرتكزات التربية المدنية د. محمد حسين على حمدان د. عبد الرحمن أبو المجد رضوان محمد لديد

ب. تحديـد وحدات التحليـل وتتـمل خمس وحدات أساسـية للتحليـل هـي: الكلمـة، الموضوع، الثخصية، المفردة، الوحدة القياسية أو الزمنية. ج. تصميم استمارة التحليل، وهي الاستمارة التى يصمدها الباحث ليفرغ فيها محتوى نهي كل مصدر - في حال تعددها - بحيث تتتهى علاقته بعد ذلك بمصدر ذلك المحتوى، وتحتوى استمارة تحليل المحتوى على الأقسام التالية.

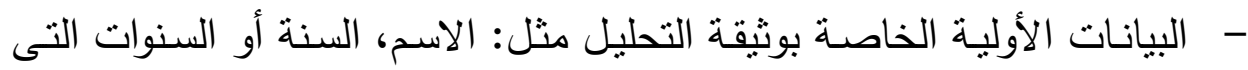
طبقت فيها الدراسة.

$$
\text { - - مئات المحتوى. - محدات التحليل. }
$$

واستمارة التحليل أثنبه مـا تكـون ببطاقـة تسـجيل المعلومـات التى يصممها الباحث لتسجيل المعلومات من كل دراسة سابقة على حدة. أ. تصميم جداول التقريغ، وهى تتعدد بتعدد تساؤلات البحث أو أهدافه، ويفرغ فيها الباحث المعلومات من استمارات التحليل تفريغًا كميًا. ب. تقريخ محتوى كل وثيقة بالاستمارة الخاصة بها، ومن ثم تفريغ ما في الاستمارات في جداول التقريغ.

ج. تطبيق المعالجات الإحصائية اللازمة الوصفية منها والتحليلية.

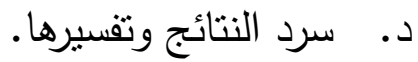
هذا وقد حدد بيرلسون خمس وحدات أساسية في التحليل نقلاً عن (المدخلى، : 10

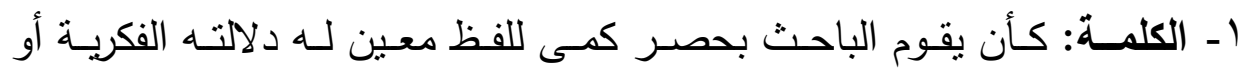
السياسية أو التربوية. r- الموضوع: وهو إما جملة او أكثر تؤكد مفهومًا معينًا سياسيًا أو اجتماعيًا أو اقتصاديًا. 
دراسة تقويمية لمقرر حقوق الإنسان بالمرحلة الجامعية في ضوء مرتكزات التربية المدنية د. محمد حسين على حمدان د. عبد الرحمن أبو المجد رضوان محمد لديد

r- الثخصـية: ويقصــ بهـا الحصـر الكمى لخصــائص وسـمات محددة ترسـم شخصية معينة، سواء أكانت تلك الثخصية شخصًا بعينه، أو فئهة من الناس في مجتمع من المجتمعات. عـ الفكرة: وهي الوحدة التى يستخدمها المصدر في نقل المعانى والأفكار.

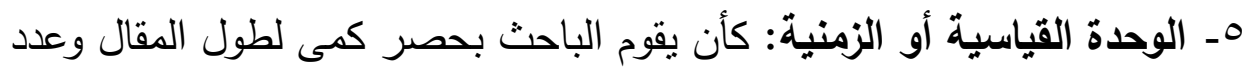

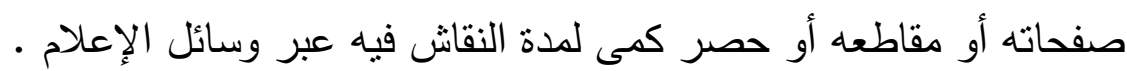
ويتطلب تحقيق خطوات أسلوب تحليل المحتوي مجموعة من المهارات التى يجب أن تتوافر لـدى المحلـل عند القيـام بعمليـة تحليـل المحتوى كمـا ذكر العيـري

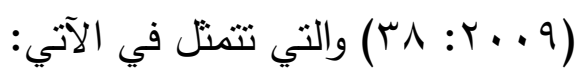
أ. التركيـز على تحليـل ظــاهر النصــوص، وعـدم التطـرق إلـى النوايـا الخفيـة للمحتوى. ب. استخدام الأسلوب العلمى المنظم في التحليل، بحيث يتم وصف المادة المحللة بموضوعية كما جاءت في الكتاب الدراسي. ج. القدرة على وضع تعريفات واضحة لوحدة التحليل وخصوصًا إذا كانت مفهومًا أو تعميًا أو قيمة أو مهارة معينة. د. إعداد الأدوات اللازمة لعملية التحليل والتى تتمثل في الاستمارات والتى لابد الته أن تخضع للتحكيم والقابلية للمعالجة الإحصائية. هـ العمل ضـمن فريق تعـاوني للمقارنـة بين المحللين، وعدم الاكتقاء بـالمجهود الثخصي للمحلل.

وفى ضوء ما سبق يتضح أن تحليل المقررات الدراسية يتبع منهجية علمية منظمة وخطوات واضحة، من حيث تحديد وحدات العينة الخاصة بالتحليل وتصميم استمارته، ومتغيرات البحث واستخدام الإحصاء الوصفي لرصد التكرارات والنسب المئوية. 
دراسة تقويمية لمقرر حقوق الإنسان بالمرحلة الجامعية في ضوء مرتكزات التربية المدنية د. محمد حسين على حمدان د. عبد الرحمن أبو المجد رضوان محمد لديد

\section{- مجتمع البحث وعينته}

اشتمل مجتمع البحث وعينته على جميع الموضوعات الواردة بمقرر حقوق

الإنسـان المقرر على طـلاب جامعـة جنوب الوادي للفصـل الدراسـي الأول مـن العـام

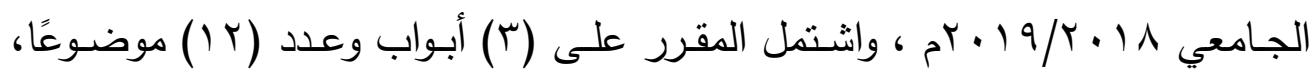
وهذا ما يوضحه الجدول التالي :

جدول (1)

أبواب وموضوعات مقر حقوق الإنسان المقرر على طلاب جامعة جنوب الوادي

\begin{tabular}{|c|c|c|}
\hline عدد الصفحات & & الموضوعات \\
\hline 1 & \multicolumn{2}{|l|}{ مقدمة المقرر } \\
\hline$r \varepsilon$ & \multicolumn{2}{|c|}{ الباب الأول : ماهية حقوق الإنسان } \\
\hline 1 & 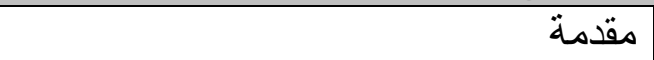 & \multirow{6}{*}{ الموضو عات } \\
\hline $\mathrm{V}$ & 1. مفهوم حقوق الإنسان & \\
\hline 7 & r. نشأة حقوق الإنسان & \\
\hline$\varepsilon$ & r. خصائص حقوق الإنسان & \\
\hline$r$ & ع. أنواع حقوق الإنسان & \\
\hline$r$ & 0. أهمية حقوق الإنسان & \\
\hline V० & \multicolumn{2}{|c|}{ الباب الثانى: المصادر القانونية لحقوق الإنسان } \\
\hline r & مقدمة & \multirow{4}{*}{ الموضو عات } \\
\hline$r \varepsilon$ & 1. المصـادر الدولية لحقوق الإنسان & \\
\hline rᄉ & r. المصادر الإقليمية لحقوق الإنسان & \\
\hline 11 & r. المصادر الوطنية لحقوق الإنسان & \\
\hline $7 \varepsilon$ & \multicolumn{2}{|c|}{ الباب الثالث: حقوق الإنسان في الإسلام } \\
\hline$r$ & مقدمة & \multirow{5}{*}{ 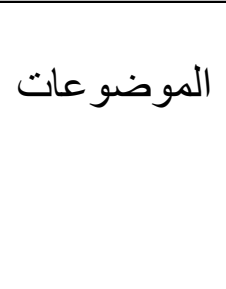 } \\
\hline 7 & l. حق الإنسان في الحباة & \\
\hline rq & r. حق الإنسان في الحرية & \\
\hline $\mathrm{V}$ & r. . حق الحرية الدينية & \\
\hline rr & ع. ـ حق المساو اة & \\
\hline 174 & \multicolumn{2}{|l|}{ 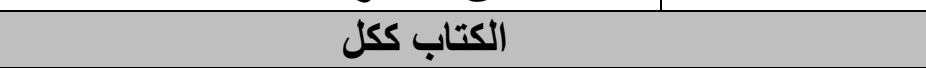 } \\
\hline
\end{tabular}


دراسة تقويمية لمقرر حقوق الإنسان بالمرحلة الجامعية في ضوء مرتكزات التربية المدنية د. محمد حسين على حمدان د. عبد الرحمن أبو المجد رضوان محمد لردان

$$
\text { إجراءات البحث. }
$$

$$
\text { لتحقيق أهداف البحث اتُبعت الإجراءات الآتية: }
$$

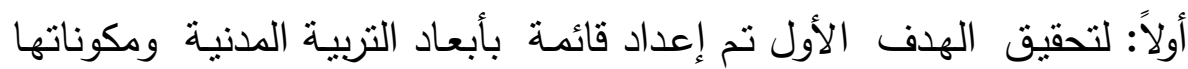
الرئيسة والفرعية الواجب تضمينها في محتوى مقرر حقوق الإنسان بالمرحلة الجامعية

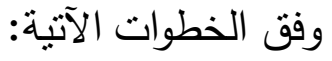

ا. الرجوع إلى الكتب والمراجع والبحوث والدراسات ذات الصلة بأهداف حقوق

الإنسان بوجه خاص، وأبعاد التربية المدنية ومكوناتها بشكل عام.

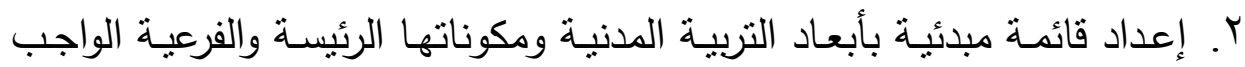

توافرها في محتوى مقرر حقوق الإنسان بالمرحلة الجامعية.

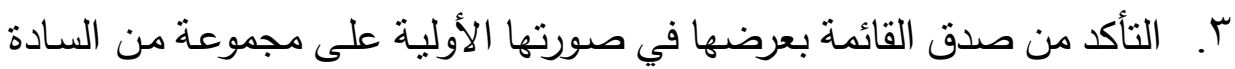

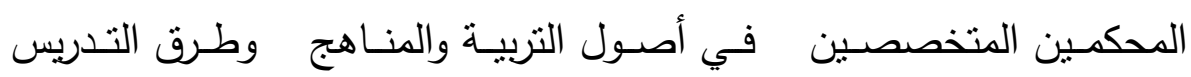
(ملحق ()، لإبداء آرائهم في أبعاد التربية المدنية الواردة في القائمة، والمكونات الرئيسة لكل بعد، ومدى انتماء كل مكون رئيس للبعد الذى يندرج تحته، وإبداء الرأي فى المكونات الفرعية الدالة على كل مكون رئيس ومدى انتمائها للمكون الرئيس والبعد الذى تتدرج تحته، حيث أظهرت نتائج التحكيم شمولية القائمة للأبعاد الثناثة للتربية المدنية والمكونات الرئيسة والفرعية لكل بعد، وأكدت على لثى

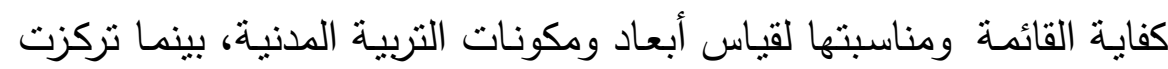
ملاحظات السادة المحكمين على تعديل ترتيب بعض المكونات الرئيسة ودمـج بعض المكونات الفرعية حيث توضح نفس الهدف، وحذف بعضها. ع. وضع القائمة في صورتها النهائية (ملحق r) بعد إجراء التعديلات التي أثنار إليها السادة المحكمون، حيث أصبحت القائمة في صورتها النهائية مكونة من: (r) أبعاد للتربية المدنية، تحتوى على (1) (1) مكون رئيس، ويندرج تحتها (0) (1) مكونًا فرعيًا موزعًا على المكونات الرئيسة للقائمة. 
دراسة تقويمية لمقرر حقوق الإنسان بالمرحلة الجامعية في ضوء مرتكزات التربية المدنية

د. محمد حسين على حمدان

د. عبد الرحمن أبو المجد رضوان محمد لديد

ثانياً: لتحقيق الهدف الثاني المتعلق بتحديد مستوى أبعاد ومكونات التربية المدنية

المتضمنة في مقرر حقوق الإنسان بجامعة جنوب الوادي تم اتباع الإجراءات الآتية:

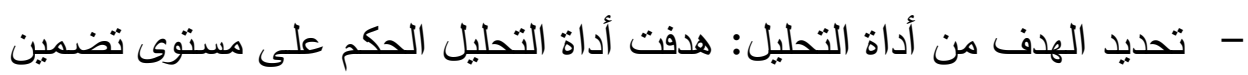
مقرر حقوق الإنسان المقرر على طلاب جامعة جنوب الوادى لأبعاد ومكونات التربية المدنية الرئيسة والفرعية.

- - إعداد أداة التحليل: المتمثلة بقائمة أبعاد ومكونات التربية المدنية السابقة ذكرها بعد وضعها أمام مقياس متدرج من التكرار والنسبة المئوية. - تحديد فئات التحليل : وهي القائمة التي تم إعدادها والتي تتضمن أبعاد التربية المدنية ومكوناتها الرئيسة والفرعية، والتي يتعين توافرها في محتوى مقرر حقوق

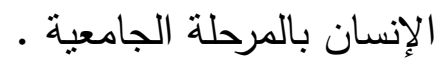
- تحديد وحدة التحليل : نظرا لطبيعة مقرر حقوق الإنسان النظرية في عرض بإن محتواه، فقد تم اعتماد وحدة السطر والفكرة بوصفهما وحدة للتحليل ويعبر عن السطر إما بالكلمة كعنوان رئيس أو أكثر من كلمتين كعنوان فرعي أو جملة تامة المعني. - تصميم استمارة التحليل والتى اشتملت على أبعاد التربية المدنية والمكونات الرئيسة والفرعية، والتأكد من صدق أداة التحليل بعرضهـا على المحكمين لإبداء آرائهم في مدى مناسبة الأداة للهدف المرجو منها، وهو تحليل محتوى مقرر حقوق الإنسان في ضوء أبعاد التربية المدنية ومكوناتها الرئيسة والفرعية.

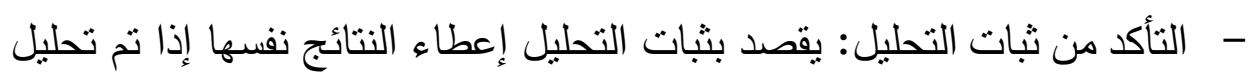
المحتوى عدة مـرات باتبـاع القواعد والإجراءات نفسـها، وقد تم تحليل مقرر حقوق الإنسان وفق استمارة التحليل بطريقتين: 
دراسة تقويمية لمقرر حقوق الإنسان بالمرحلة الجامعية في ضوء مرتكزات التربية المدنية د. محمد حسين على حمدان

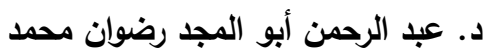

أـ الثبات الخارجي بين المحلين وذلك بقياس الاتساق مع زميلة أخرى" تخصص

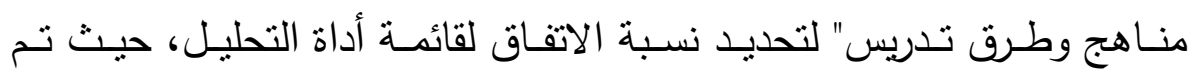
الاجتماع معها، وتوضيح طريقة التحليل لها، وقد ثم إجراء التحليل كل على حدة بإجراء علية التحليل على جميع الموضوعات الواردة بمقرر حقوق الإنسـان، وفق استمارة التحليل المخصصـة لذلك، وبلغت نسبة الاتفاق \%90..r ب- الثبات الداخلي وذلك بإعادة التحليل مرة ثانية في شهر ديسمبر تقريبًا بعد شهر من التحليل الأول، حيث أجري التحليل الأول بشهر نوفمبر، وتم حساب معامل

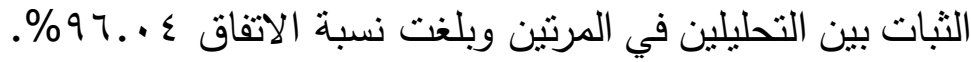
- - البدء بعملية التحليل وفق الخطوات الآتية: أ- البدء بقراءة محتوى كل موضوع من الموضوعات المتضمنة في محتوى مقرر حقوق الإنسان، وتحديد وحدات التحليل المتضمنة في كل موضوع وفق الاستمارة المعدة لهذا الغرض. الإن.

ب- رصد تكرارات ظهور فئات التحليل (أبعاد التربية المدنية ومكوناتها الرئيسة والفرعية) في محتوى مقرر حقوق الإنسان بالمرحلة الجامعية ( ملحق ؟).

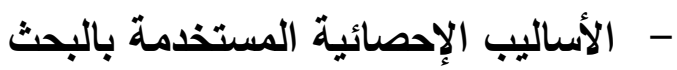
تم استخدام الأساليب الإحصائية التالية في معالجة بيانات البحث لتحقيق أهدافه: - التكرارات حيث تم استخلاص مجموعات تكرار لكل مكون فرعي - - - معبب المئوية حيث تم احتساب النسبة المئوية لتكرار كل مكون فرعي. - - معادلة كوبر وتم استخدام هذه المعادلة في حساب نسبة الاتفاق بين المحللين. - - معادلة هولستي وتم استخدام هذه المعادلة في حساب معامل ثبات أداة تحليل المحتوي. 
دراسة تقويمية لمقرر حقوق الإنسان بالمرحلة الجامعية في ضوء مرتكزات التربية المدنية د. محمد حسين على حمدان د. عبد الرحمن أبو المجد رضوان محمد لديد

\section{- - عرض نتائج البحث وتفسيرها ومناقشتها}

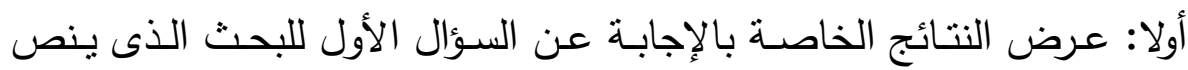

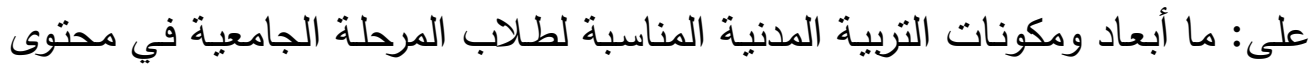
مقرر حقوق الإنسان؟ تم إعداد قائمة بأبعاد ومكونات التربية المدنية الرئيسة والفرعية الواجب توافرها في محتوى مقرر حقوق الإنسان بالمرحلة الجامعية، وقد ثم عرض خطوات إعدادها في

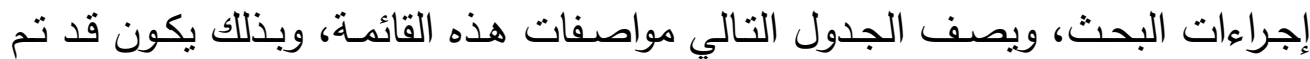

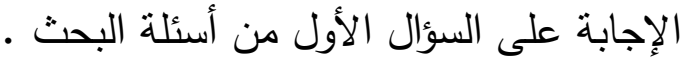
جدول (r) مواصفات قائمة أبعاد ومكونات التربية المدنية في مقرر حقوق الإنسان بالمرحلة الجامعية

\begin{tabular}{|c|c|c|c|}
\hline المكونات الفرعية & المكونات الرئيسة & الأبعاد & م \\
\hline 0 & · المجتمع المدنى & \multirow{4}{*}{ المعرفي } & \multirow[t]{4}{*}{1} \\
\hline$\varepsilon$ & ل المجتمع الدولي & & \\
\hline 0 & ل المواطنة & & \\
\hline 0 & - الديمقراطية & & \\
\hline$\varepsilon$ & - مهارات فكرية & \multirow{3}{*}{ المهاري } & \multirow{3}{*}{ r } \\
\hline r & · مهارات المشاركة & & \\
\hline r & - مهارات التفكير الناقد والابداعي & & \\
\hline$\varepsilon$ & 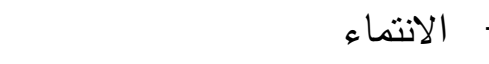 & \multirow{4}{*}{ 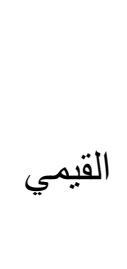 } & \multirow{4}{*}{$r$} \\
\hline r & - المسئولية المجتمعية & & \\
\hline 0 & - المشاركة السياسية & & \\
\hline$\varepsilon$ & 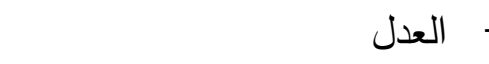 & & \\
\hline$\leqslant 0$ & 11 & & لمج - ل المج \\
\hline
\end{tabular}

ثانياً: عرض النتائج الخاصـة بالإجابة عن السؤال الثاني للبحث الذى ينص

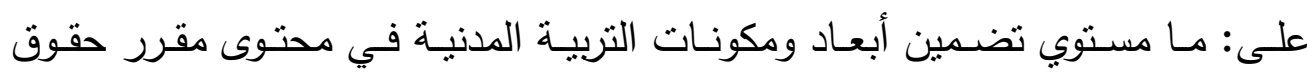
الإنسان بجامعة جنوب الوادي؟ 
دراسة تقويمية لمقرر حقوق الإنسان بالمرحلة الجامعية في ضوء مرتكزات التربية المدنية

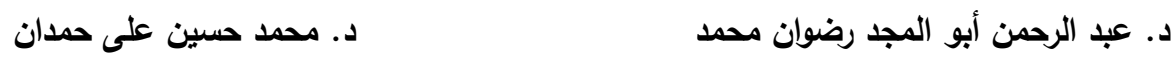

للإجابـة عن هذا السؤال تم تحليل مقرر حقوق الإنسـان المقرر على طـلاب

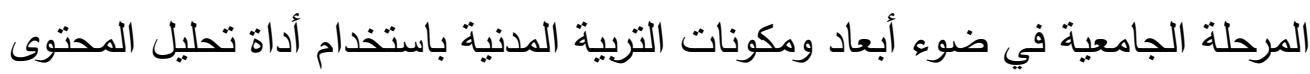

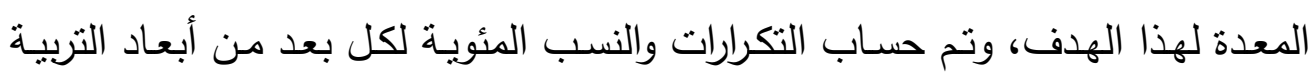

المدنية ومكوناتها الرئيسة والفرعية، وكانت النتائج كما هو موضح في الجدول التالي:

جدول (r): نتائج تحليل أبعاد التريبة المدنية المتضمنة فى مقرر حقوق الإنسان

بالمرحلة الجامعية

(المكونات المتوفرة والتكرارات والنسب المئوية )

\begin{tabular}{|c|c|c|c|c|c|c|}
\hline \multicolumn{3}{|c|}{ التكرارات وإلنسب المئوية } & \multicolumn{2}{|c|}{ عدد المكونات الفرعية } & \multirow[t]{2}{*}{ وفقى القائمة الفرعية } & \multirow[t]{2}{*}{ أبعاد التربية المدنية } \\
\hline الترتيب & النسبة & التكرار & النسبة & العدد & & \\
\hline 1 & $0 \wedge .1 \mathrm{~V}$ & rqr & VT.१A & $1 \leq$ & 19 & البعد المعرفي \\
\hline r & $r 1.1 r$ & 1.7 & $\varepsilon \ldots$ & $\varepsilon$ & 1. & البعد المهاري \\
\hline r & $r \cdot . v 1$ & $1 \cdot \varepsilon$ & Tr.o. & 1. & 17 & البعد القيمى \\
\hline \multicolumn{2}{|c|}{$\% 1 \ldots$} & $0 . r$ & \%Tr.rY & rA & $\leq 0$ & المجموع \\
\hline
\end{tabular}

يتضح من الجدول السابق ما يلي :

أن النسبة المئوية العامة لعدد مكونات التربية المدنية المتوفرة فى مقرر حقوق

الإنسان بالمرحلة الجامعية تساوي Y. Y. T \% وهى نسبة منوسطة، حيث جاءت نسبة

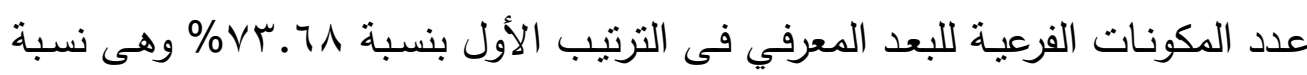

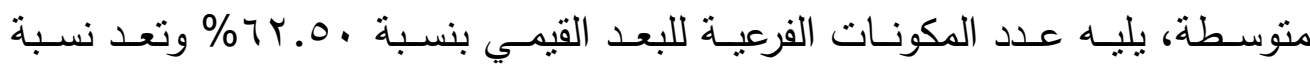

متوسطة، وفى التزتيب الثالث عدد المكونات الفرعية للبعد المهاري بنسبة . ؛ \% وتعد نسبة منخفضة، مما يشبر إلى أن أبعاد ومكونات التربية المدنية متوافرة بمقرر حقوق الإنسان بنسب متفاوتة.

بكن الرجوع لملحق التحليل رقم (r) 
دراسة تقويمية لمقرر حقوق الإنسان بالمرحلة الجامعية في ضوء مرتكزات التربية المدنية

د. محمد حسين على حمدان

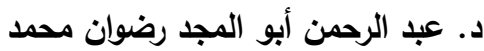

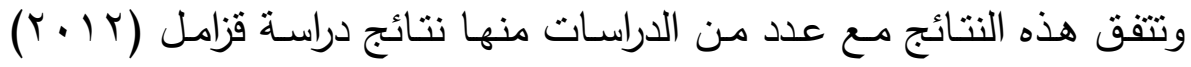

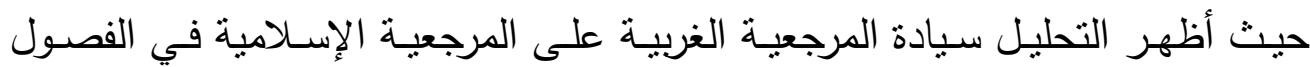
الأربعة للمقرر والمحتوى ككل ، ولم يتتاسب المقرر مع طبيعة الدراسـة بكليات التربية،

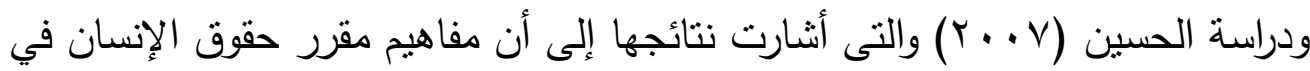
الإسلام جاء بمفردات متتاثرة فى بعض المقررات ، وهناك العديد من الموضوعات ذات الاهميـة ولم يـتم تتاولها فـى المفردات الثقافيـة لمقرر حقوق الانسـان، ودراسـة بـادي

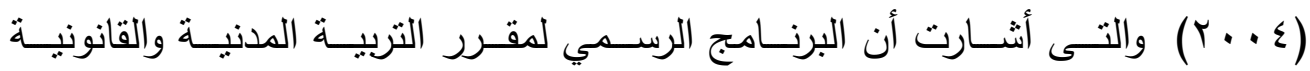
والاجتماعية للصف الأول الثانوي في فرنسا قد تكون من مجموعة محددة من المفاهيم المدنية والقانونية والاجتماعية، وأن فئات حقوق الانسان متضمنة فى مفهومات التربية

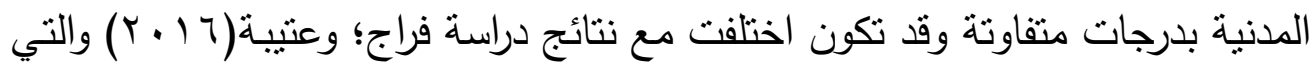
أثـارت نتائجها أن درجة نوافر مفاهيم وقضايا حقوق الانسان في توصيفات المقررات الجامعية بصورة مجملة جاءت ضعيفة.

أن محتوى مقرر حقوق الإنسان بالمرحلة الجامعية قد تضمن أبعاد التربية المدنية

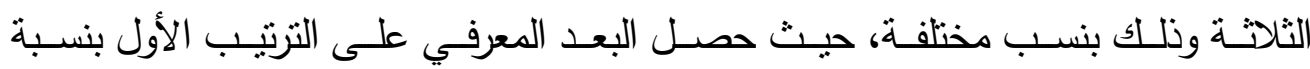

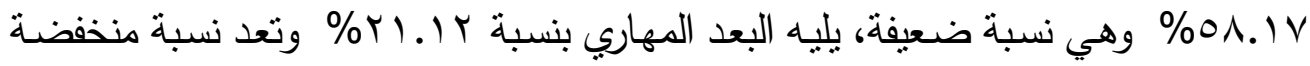
جدًا، بينما حصل البعد القيمي على التزتيب الثالث بنسبة (Y. . . . وهى نسبة منخفضة جدًا.

وللتعـرف على التكرارات والنسبة المئويـة لكل بعـد مـن أبعـاد التربيـة المدنيـة

$$
\text { ومكوناتها الرئيسة والفرعية، تم الآتي: }
$$

(1) البعد المعرفي للتربية المدنية ومكوناته الرئيسة والفرعية

تم حسـاب التكـرارات والنسـب المئويـة بشـل تقصسيلي للبعد المعرفي للتربيـة المدنية ومكوناته الرئيسة والفرعية، وذلك لمعرفة مستوى تضمين محتوى مقرر حقوق الإنسان لها، فكانت النتائج كما هو موضح في الجدول التالي: 
دراسة تقويمية لمقرر حقوق الإنسان بالمرحلة الجامعية في ضوء مرتكزات التربية المدنية د. محمد حسين على حمدان د. عبد الرحمن أبو المجد رضوان محمد لديد لإنيان

جدول (؛): نتائج تحليل البعد المعرفي للتربية المدنية المتضمنة فى مقرر حقوق الإنسان بالمرحلة الجامعية (المكونات المتوفرة والتكرارات والنسب المئوية )

\begin{tabular}{|c|c|c|c|c|c|c|}
\hline \multicolumn{3}{|c|}{ للمؤشرات المتوفرة بالمقرر } & \multicolumn{2}{|c|}{ عدد المكونات الفرعية } & \multirow{2}{*}{ الفرعية وفق المكونات } & \multirow{2}{*}{ اللبعد المعرفي الرئيسة } \\
\hline | الترتيب & النسبة & التكرار & النسبة & العدد الع & & \\
\hline$\varepsilon$ & 1.21 & 0 & $\varepsilon \cdot$. & r & 0 & مكون المجتمع المدنى \\
\hline r & 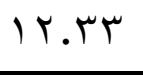 & 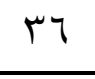 & $0 \cdot . \cdot$ & r & $\varepsilon$ & مكون المجتمع الدولى \\
\hline 1 & 77.1. & 194 & $1 \cdots$ & 0 & 0 & مكون المواطنة \\
\hline r & 19.17 & $0 \wedge$ & $1 \cdots$ & 0 & 0 & مكون الايمقراطية \\
\hline \multicolumn{2}{|c|}{$\% 1 \ldots$} & rqr & 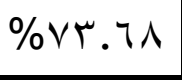 & $1 \varepsilon$ & 19 & المجموع \\
\hline
\end{tabular}

يتضح من الجدول السابق ما يلي : - أن عدد المكونات الفرعية للبعد المعرفي المتوفرة فى مقرر حقوق الإنسان بالمرحلة

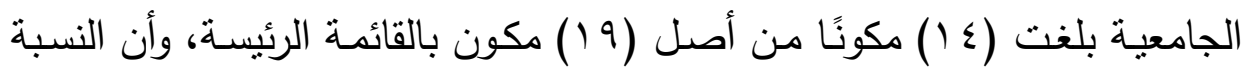

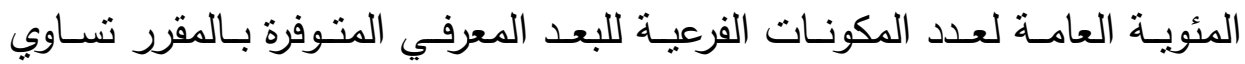

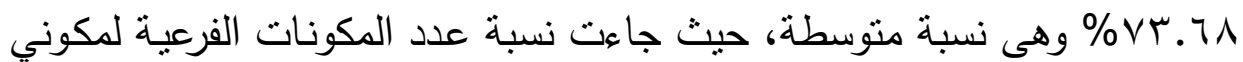
المواطنـة والديمقراطية فى الترتيب الأول بنسبة . . 1 \% وهى نسبة مرتفعـة جدًا، يليها عدد المكونات الفرعية لمكون المجتهع الدولي بنسبة . 0\% ، وفى الترتيب

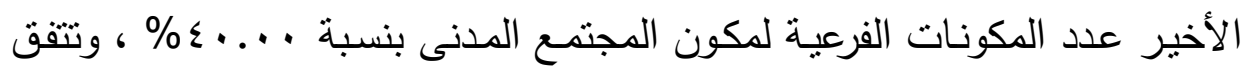

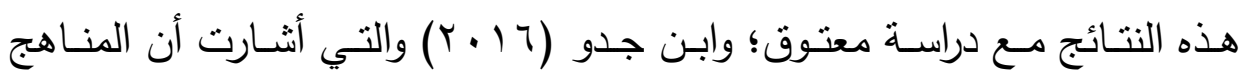
والمقررات الدراسية ركزت بشكل كبير على بعد المعارف الخاصة بالمواطنة وحقوق

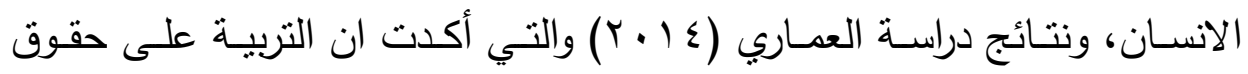
الانسان اهتمت بالجانب المعرفي وان المؤسسات التربوية لها دور كبير في نشر التر التران وترسيخ قيم المواطنة والسلوك المدني إلا أنها غير قادرة وحدها على ذلك. - أن محتوى مقرر حقوق الإنسان قد تضمن المكونات الأربعة الرئيسة للبعد المعرفي

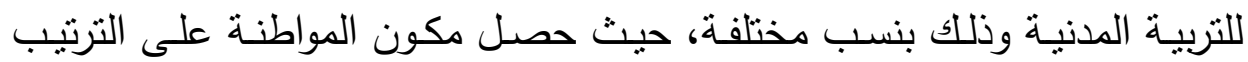


دراسة تقويمية لمقرر حقوق الإنسان بالمرحلة الجامعية في ضوء مرتكزات التربية المدنية

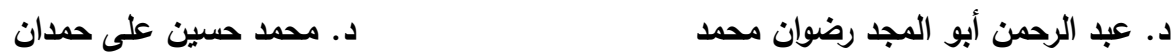

الأول بنسـبة • ( ـ7\% وهـى نسـبة متوسـطة ، يليـه مكسون الديمقراطيـة بنسـبة

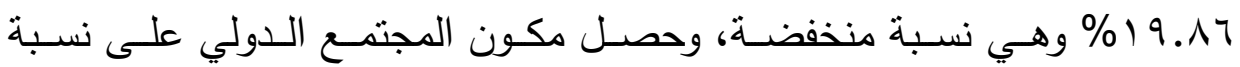

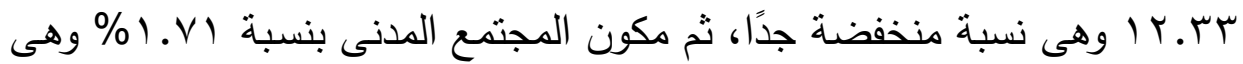
نسبة منخفضة جدًا.

(Y) البعد المهاري للتربية المدنية ومكوناته الرئيسة والفرعية تم حسـاب التكـرارات والنسـب المئويـة بشـكل تفصـيلي للبعـد المهارى للتربيـة المدنية ومكوناته الرئيسة والفرعيـة، وذلك لمعرفة مستوي تضمين محتوى مقرر حقوق

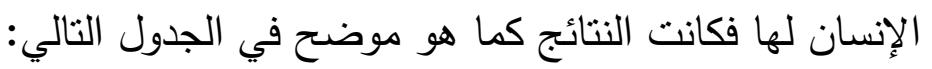
جدول (•): نتائج تحليل البعد المهاري للتربية المدنية المتضمنة فى مقرر حقوق الإن الإنسان بالمرحلة الجامعية (المكونات المتوفرة والتكرارات والنسب المئوية )

\begin{tabular}{|c|c|c|c|c|c|c|}
\hline \multicolumn{3}{|c|}{ التكرارات والنسب المئوية } & \multicolumn{2}{|c|}{ علد المكونات الفرعية } & \multirow{2}{*}{ عدال الفرعية وفق } & \multirow[t]{2}{*}{ اللبكونات الرئيسة } \\
\hline الترتيب & النسبة & التكرار & النسبة & العدد & & \\
\hline 1 & $9 V .1 V$ & $1 . r$ & 0 . & $r$ & $\varepsilon$ & مكون المهارات فكرية \\
\hline r & r.Ar & r & איזr & 1 & r & مكون المهارات المشاركة \\
\hline r & $\ldots$ & $\cdots$ & .. & $\cdots$ & r & مكون مهارات التفكير \\
\hline$\% 1$. & & 1.7 & $\%+\ldots$ & $r$ & 1. & المجموع \\
\hline
\end{tabular}

يتضح من الجدول السابق ما يلي :

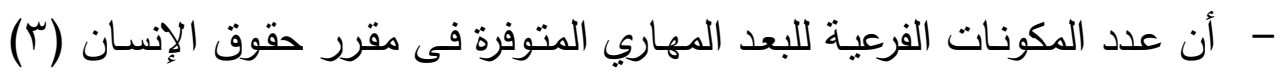

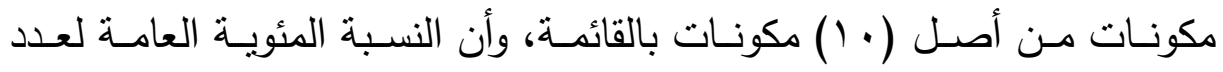

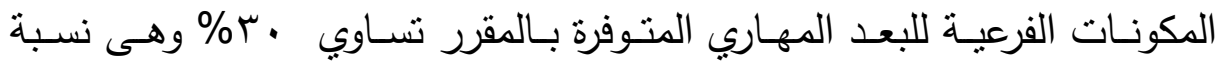
منخفضـة، حيث جاءت المكونات الفرعية لمكون المهارات الفكريـة فى الترتيب الأول بنسبة •0\%؛ يليهـا المكونـات الفرعيـة لمكون مهارات المشـاركة بنسبة

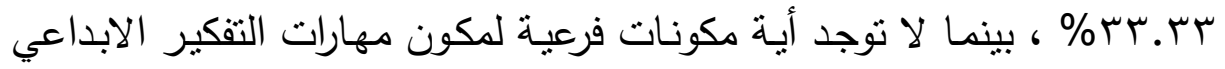

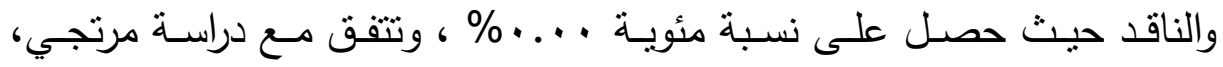


دراسة تقويمية لمقرر حقوق الإنسان بالمرحلة الجامعية في ضوء مرتكزات التربية المدنية

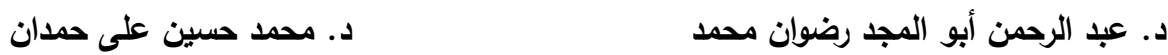

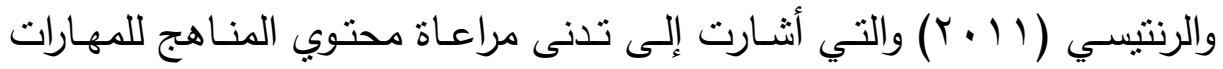

$$
\text { والقيم المدنية وعدم التوازن فيها. }
$$

- - أن محتوى مقرر حقوق الإنسـان للمرحلة الجامعيـة قد تضمن مكونين فقط من وعن

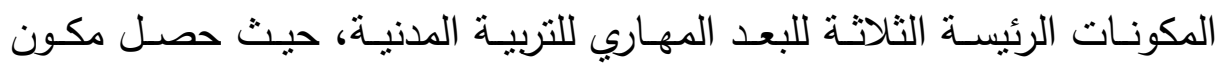
المهارات الفكرية على الترتيب الأول بنسبة و \% و وهي نسبة عالية، يليه

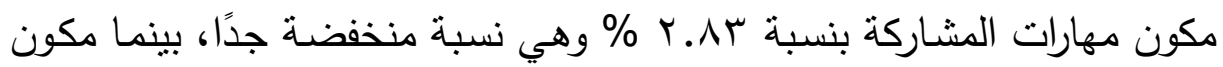
مهارات التفكير الإبداعي والناقد غير منضمن بالمقرر حيث حصل على نسبة $\%$....

\section{(ץ) البعد القيمى للتربية المدنية ومكوناته الرئيسة والفرعية}

تم حساب التكرارات والنسب المئوية بشكل تفصيلي للبعد الثالث للتربية المدنية "البعد القيمي" ومكوناته الرئيسة والفرعية ، لمعرفة مستوي تضمين محتوى مقرر حقوق

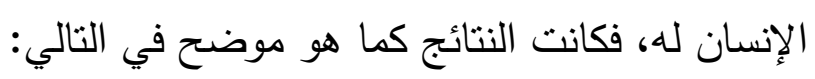

جدول (ج): نتائج تحليل البعد القيمي للتربية المدنية المتضمنة في مقرر حقوق

\begin{tabular}{|c|c|c|c|c|c|c|}
\hline \multicolumn{3}{|c|}{ التكرارات والنسب المئوية } & \multicolumn{2}{|c|}{ عدد المكونات الفرعية } & \multirow{2}{*}{ الفرعية وفق المونات } & \multirow{2}{*}{ اللبعد القيمي الرئيسة } \\
\hline الترتيب & النسبة & 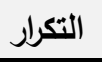 & النسبة & 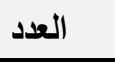 & & \\
\hline$\varepsilon$ & $0 . V V$ & 7 & vo... & r & $\varepsilon$ & مكون الانتماء \\
\hline r & $1.9 r$ & r & מז.זr & 1 & r & مكون المسئولية المجتمعية \\
\hline$r$ & $11.0 \leqslant$ & ir & $7 \ldots$ & r & 0 & مكون المشاركة السياسية \\
\hline 1 & $\Lambda . V \vee V$ & $\wedge \varepsilon$ & vo... & r & $\varepsilon$ & مكون العدل \\
\hline \multicolumn{2}{|c|}{$\% 1 \ldots}$. & $1 \cdot \varepsilon$ & \%тr.o & 1. & 17 & المجموع \\
\hline
\end{tabular}

الإنسان بالمرحلة الجامعية (المكونات المتوفرة والتكرارات وإلنسب المئوية)

يتضح من الجدول السابق ما يلي:

- أن عدد المكونات الفرعية للبعد القيمي للتربية المدنية المتوفرة فى مقرر حقوق

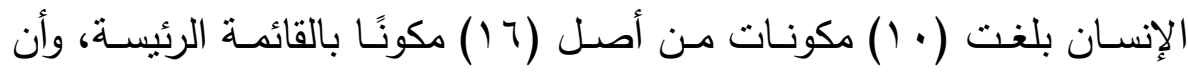
نسبتها المئوية العامة بلغت ه.r7\% ، ، حيث احتلت المكونات الفرعية لمكوني 
دراسة تقويمية لمقرر حقوق الإنسان بالمرحلة الجامعية في ضوء مرتكزات التربية المدنية

د. محمد حسين على حمدان

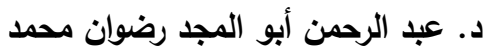

الانتماء والعدل على نسبة نوافر \% \% \% بينما جاءت المكونات الفرعية لمكون المشاركة السياسية بنسبة توافر ـ \%٪، وفى الترتيب الأخير جاءت المكونات الفرعية لمكون المسئولية الاجتماعية بنسبة سr.rr\%، وتتفق مع نتائج دراسة درويش ( • • (Y) والتي أنشارت أن هناك ضعفا في مساهمة الكتب الدراسية في

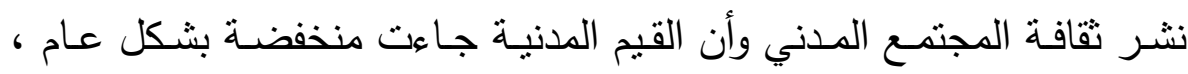

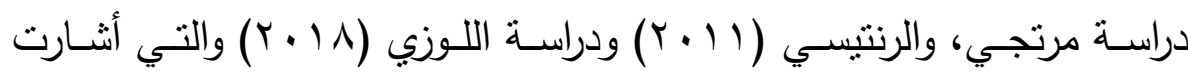

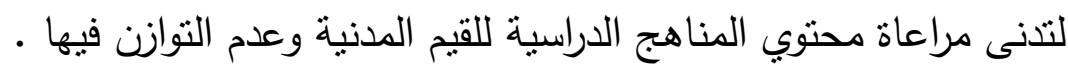
- أن محتوى مقرر حقوق الإنسان بالمرحلة الجامعية قد تضمن المكونات الأربعة الرئيسـة للبعد القيمي للتربية المدنيـة وذلك بنسب مختلفة، حيث حصل مكون

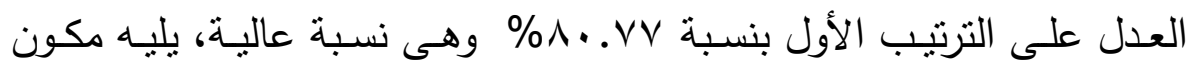
المشاركة السياسية بنسبة ؟0. 11\% وهى نسبة منخفضة، وفى الترتيب الثالث مكون الانتماء بنسبة منخفضـة بلغت .VV . o ، وفى المرتبة الرابعة والأخيرة مكون المسئولية المجتمعية بنسبة ب9 1 \% \% وهى نسبة منخفضة . ثالثًا: مناقشة النتائج وتفسيرها أظهرت النتائج التى نم التوصل إليها ما يلى مانى: - أن محتوى مقرر حقوق الإنسان تضمن ( • (1) مكونات رئيسة من أصل (1)

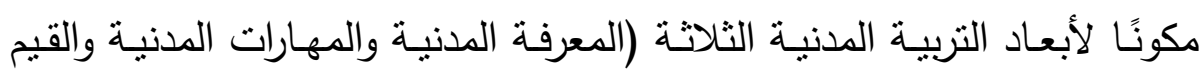
المدنيـة) وذلك بنسب مختلفة، حيث كثفت النتائج أن مكون مهارات التفكير الإبداعي والناقد والتابع لبعد مهارات التربية المدنية غير منوافر بالمقرر، كما

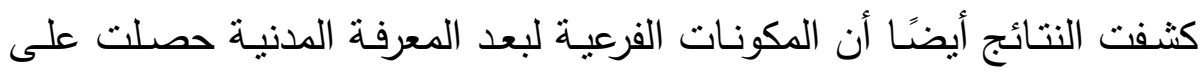

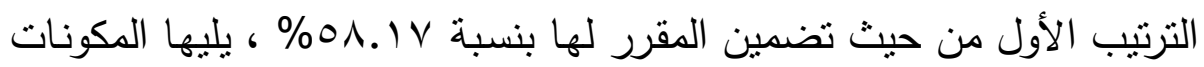

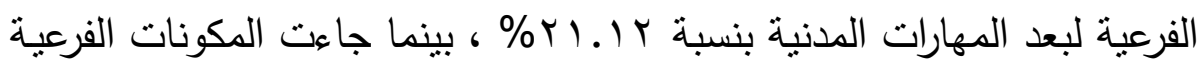

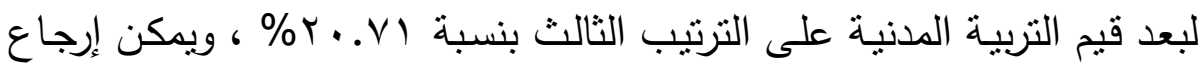
تلاك النتائج إلى موضوعات محتوى مقرر حقوق الإنسان وطريقة عرضها والتى 
دراسة تقويمية لمقرر حقوق الإنسان بالمرحلة الجامعية في ضوء مرتكزات التربية المدنية

د. محمد حسين على حمدان

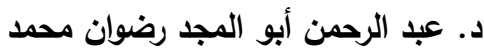

لا تسـهم أو تتيح الفرصـة للطالب لممارسـة مهارات التفكير الإبـداعي والناقد والمشاركة الفاعلة فى تكوين الآراء حول القضايا العامة ونقدها بطرق صحيحة، كما قد يرجع الارتفاع الكبير فى نسبة تضمين المعرفة المدنية وبصفة خاصـة

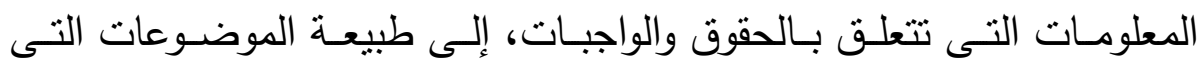
يتضمنها المقرر والتي تركز في كثير منها على المعارف والمعلومات النظرية المرتبطة بالحقوق والحريات، والقوانين الدولية والمحلية المتعلقة بحقوق الإنسان، إضافة إلى الموضوعات المتعلقة بحقوق الإنسان في الثربعة الإسلامية. - أن مقرر حقوق الإنسـان قد تضـمن المكونـات الأربعـة الرئيسـة للبعد المعرفي الإني للتربية المدنية وذلك بنسب مختلفة، حيث حصل مكون المواطنة على الترتيب الأول بنسبة • ـ ـ7\% وهـي نسبة منوسـة، يليـه مكسون الديمقراطيـة بنسبة 719.1 19 وهي نسبة منخفضـة، بينما جاء مكون المجتمع الدولي في المرتبـة

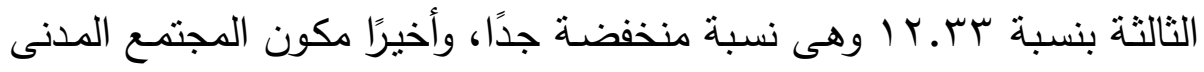

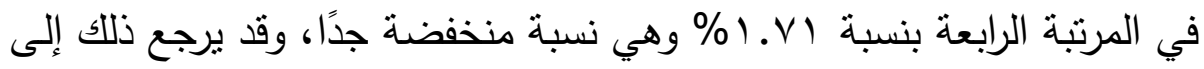
تركيز الموضـوعات التى بتضـنها المقرر - بشكل أساسي - على المفاهيم والمعلومـات والقوانين المتعلقـة بالمواطنـة مثل : المعلومـات عـن أدوار الأفراد وحقوقهم في المجتمع الديمقراطى، ومعرفة الدستور الذى يقوم عليه نظام الحكم ومـا يضـنه للمـواطنين مـن حقوق ومسئوليات، وبعض الموضـوعات المتعلقة بالديمقراطية منل : معرفة المبادئ والأسس التى ثقوم عليها الديمقراطية، والقوانين والتشـريعات التي تؤكد على احترام قيم العدالـة والحـوار وحريـة التفكير النقد واحترام الآخر واحترام مبدأ المساوة، وذلك على حساب المعارف والمعلومـات

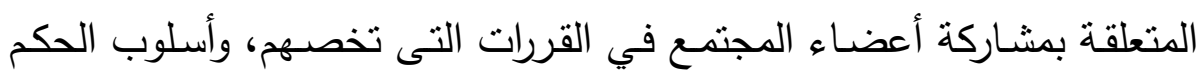
القائم على سلطة الثعب، وكيفية ممارسة الشعب لحقه في اختيار السلطة التى تحكمـه، والمعـارف والمعلومـات المتعلقـة بـالمجتمع الـدولى وأسـس المواطنـة

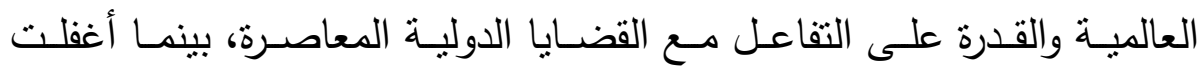


دراسة تقويمية لمقرر حقوق الإنسان بالمرحلة الجامعية في ضوء مرتكزات التربية المدنية

د. محمد حسين على حمدان

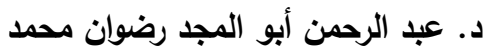

موضـوعات المقرر - تقريبًا - المعــارف والمعلومــات عـن المجتمـع المـدنى ومكوناته وأهدافه وأهميته ووظائفه التى يقوم بها داخل المجتمع والمبادئ التى يقوم عليها، لذللك جـاءت نسبة تمثيـل هذه الموضـوعات في المقرر بشـكل منخفض جدًا. - تضــن محتـوى مقـرر حقوق الإنسـان للمرحلـة الجامعيـة مكـونين فقط مـن المكونات الثلاثتة الرئيسـة للبعد المهاري للتربية المدنية، حيث خـا المقرر من الإن

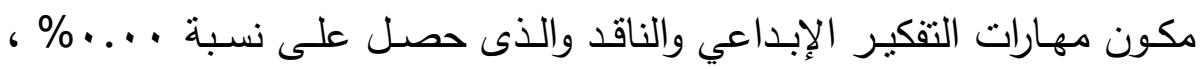

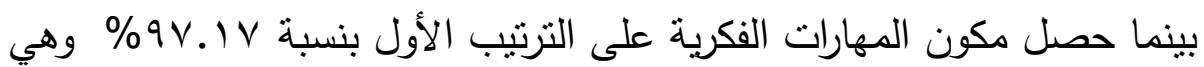

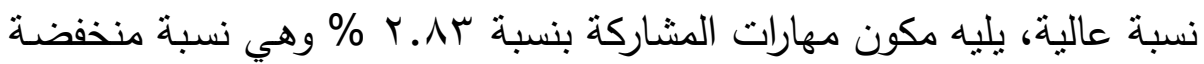
جدًا، وقد يرجـع الارتفاع في نسبة تمثيل بعض المهارات الفكريـة إلى طبيعـة الموضـوعات التـى تضــنها محتـوى مقـرر حقـوق الإنسـان وبصـفة خاصــة

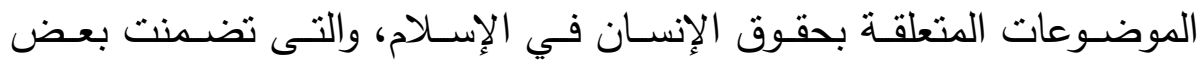
الموضوعات التى تتمى لدى الطلاب بعض المهارات الفكرية ومهارة المشاركة مثل: القدرة على التفكير النقدى في قضية معينة، والبحث عن الحجج والأدلة تجاه موضدوع معين، والقدرة على رصد الأحداث والقضـايا العامـة، بينمـا خـلا المقرر مـن الموضـوعات التى تشـجع الطـلاب على ممارسـة وتتميـة مهارات

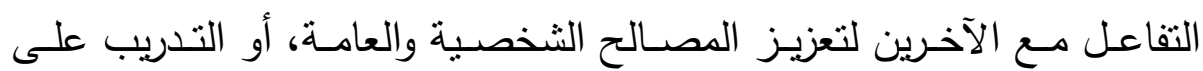
مهارات التفكير الإبداعى والناقد منل: مهارة المشاركة والإسهام النقدي في حياة

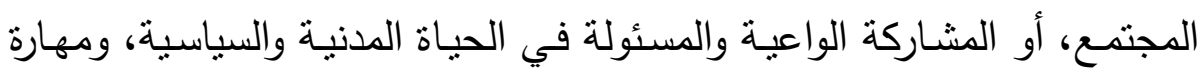

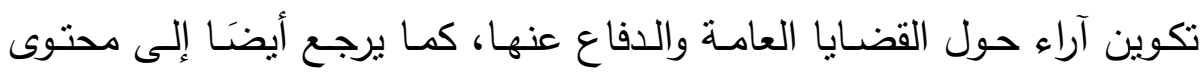
الموضوعات التى تضمنها المقرر وطريقة عرضـها، والتى جاءت في مجملها

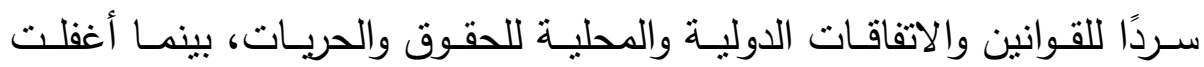
المواقف والخبرات التعليمية والأنشطة التى تتمى لدى المتعلم المهارات العقلية العليا كالتفكير الإبداعي والناقد، وخلت من الأنشطة الصفية واللاصفية المختلفة 
دراسة تقويمية لمقر حقوق الإنسان بالمرحلة الجامعية في ضوء مرتكزات التربية المدنية د. محمد حسين على حمدان د. عبد الرحمن أبو المجد رضوان محمد لديد

التى تشـجع الطـلاب على المشـاركة في الندوات والمؤتمرات السياسية، بمـا يمكنهم مـن المتابعة السياسية للقضـايا والأحداث، وتكوين رأى حول القضـايا المطروحة ونقدها والدفاع عنها. - اشتمل محتوى مقرر حقوق الإنسان بالمرحلة الجامعية على المكونات الأربعة الرئيسـة للبعد القيمي للتربيـة المدنية ولكن بنسب مختلفة، حيث حصل مكون

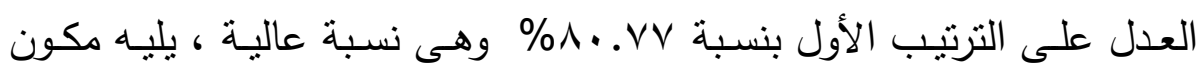

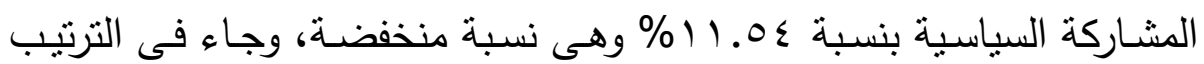

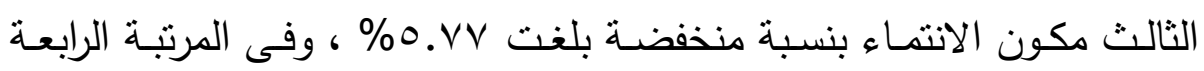

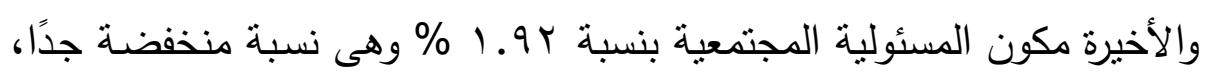
وقد يرجع ذلك إلى تركيز المحتوى على القيم التى تؤكد على العدالة وعدم التمييز بأثكاله المختلفة أو العدالة السياسية والاقتصادية والعدالة داخل الأسرة،

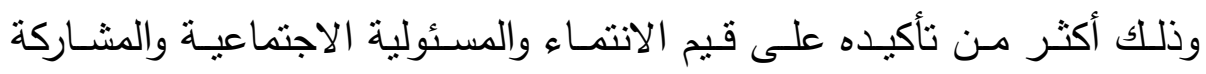
السياسية، كما أغفل محتوى المقرر الأنشطة التى تساعد الطلاب على الانخراط

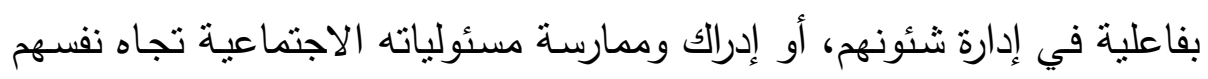
والآخرين، والقدرة على تكوين وعى يوضح العلاقة بين الحقوق والمسئوليات في الي إطار قانونى يسنتد إلى الولاء والانتماء للوطن، والاهتمام بالمشاركة الفاعلة فى ولى

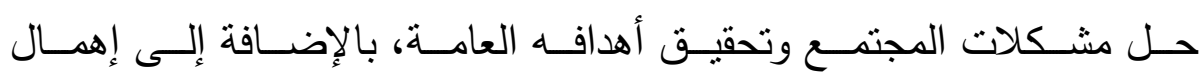
الموضـوعات التـى تمكـن الطالب مـن تكـوين اتجـاه إيجـابي نحـو المثـاركة

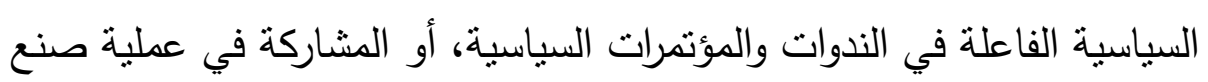
القرار السياسـى بطريقـة مباشـرة وغيـر مباثـرة، والمتابعـة السياسـية للأحـداث والقضايا المجتمعية، والترشح أو المشاركة في الانتخابات. 
دراسة تقويمية لمقرر حقوق الإنسان بالمرحلة الجامعية في ضوء مرتكزات التربية المدنية د. محمد حسين على حمدان د. عبد الرحمن أبو المجد رضوان محمد لديد

رابعًا: إجابـة السؤال الثالث والذى ينص على مـا التصور المقترح لتطوير محتوي مقرر حقوق الإنسان في ضوء أبعاد ومكونات التربية المدنية ؟ في ضوء الإطار النظري للبحث، واستتادًا إلى مـا تم التوصل إلبهه من نتائج تحليل محتوى مقرر حقوق الإنسان لطلاب جامعة جنوب الوادى في ضوء مرتكزات التربية المدنية، تبين وجود قصور وتدنى في مستوى تضمين محتوى المقرر لأبعاد

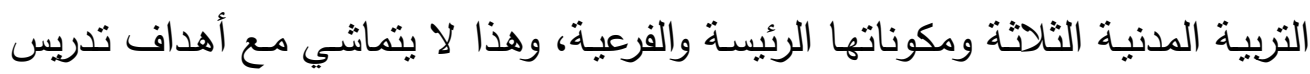
مقرر حقوق الإنسان ، والتوجهات المحلية والعالمية التى تتادى بضرورة تتمية معارف ومهارات وقيم التربية المدنية، ومن ثم تم بناء تصور مقترح لتضمين مرتكزات التربية المدنية في محتوى مقرر حقوق الإنسان بالمرحلة الجامعية بغرض تطويره وفق الآتي : أ. مبررات التصور المقترح ينطلق التصور المقترح من الاعتبارات التالية: - توصيات معظم البحوث والدراسات العربية والأجنبية بأهمية تضمين مرتكزات التربية المدنية في جميع المقررات والمناهج في كافة المراحل التعليمية .

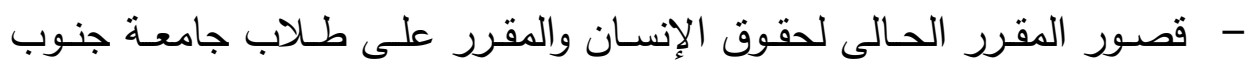
الـوادى في مسـتوى تضـمين محتـوى المقـرر لأبعـاد التربيـة المدنيـة الثلاثـة ومكوناتها الرئيسة والفرعية. - الحاجة الماسـة لتعليم وتدريب طـلاب الجامعة على مهارات المشـاركة واتخـاذ القـرارات وإعـدادهم ليكونــوا قـادرين علـى المشـاركة فـى الحيـاة الاجتماعيـة والسياسية ومن ثم يتحقق الصالح العام للمجتمع. - تمية الوعى السياسى والاجتماعي والاقتصادي للطلاب، وتزويدهم بالقدرات الضرورية التى تؤهلهم للمشاركة المجتمعية الفاعلة فى الحياة العامة وقد يتحقق بـى ذللك من خلال تضمين بعد المعارف المدنية. 
دراسة تقويمية لمقرر حقوق الإنسان بالمرحلة الجامعية في ضوء مرتكزات التربية المدنية د. محمد حسين على حمدان د. عبد الرحمن أبو المجد رضوان محمد لديد

- تعميق الانتماء وتتمية الاعتزاز والولاء للطلاب، والتعريف بالحقوق والواجبات، وتدعيم قيم الحرية والديمقراطية والمواطنة ، وقد يتحقق ذللك من خلال تضمين بعدي المهارات المدنية والقيم المدنية. ب- المكونات الرئيسة للتصور المقترح يتضمن التصور المقترح مجموعة من المكونات الرئيسة منها:

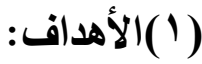

يهدف التصـور المقترح إلى تضـمين أبعـاد التربيـة المدنيـة ومكوناتها الرئيسـة والفرعية بمقرر حقوق الإنسان وذلك من أجل تحقيق الأهداف الفرعية التالية:

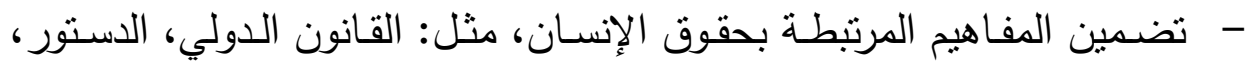

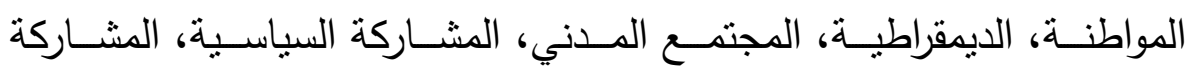
المجتمعية، العدالة الاجتماعية. - تحديد مواد الدستور المصرى التى تؤكد على احترام حقوق الإنسان وتحقيق المواطنة الكاملة . مولة - استخلاص الطرق والضمانات الكفيلة لحقوق الإنسان محليًا وعالميًا. - تتمية الروح الوطنية لدي الطلاب من خلال توعيتهم بحقوقهم وواجباتهم. - توضيح القضايا المتعلقة بحقوق الإنسان وتحليلها وإيجاد الطرق المشروعة لحلها. - - تتمية قيم العمل التطوعى لدى الطلاب . - -

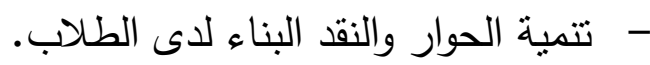
- تشجيع الطلاب نحو المشاركة السياسية الفعالة فى المجتمع. - تعويد الطـلاب على التفكير النقدى الذى يسـاعدهم على النظرة الموضـوعية

$$
\text { لمشكلات الحياة. }
$$

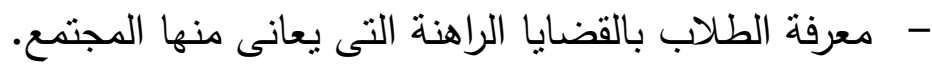
- توعية الطلاب بمؤسسات المجتمع المدنى ودورها فى المجتمع المحلى. 
دراسة تقويمية لمقرر حقوق الإنسان بالمرحلة الجامعية في ضوء مرتكزات التربية المدنية

د. محمد حسين على حمدان

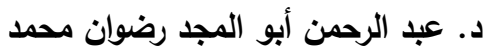

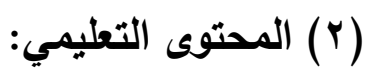

فيما يتعلق بمحتوى مقرر حقوق الإنسان فقد أثنارت نتائج تحليل المقرر إلى وجـود تقـاوت في مسـتوى تضـمين أبعـاد ومكونـات التربيـة المدنيـة في مقرر حقوق التون

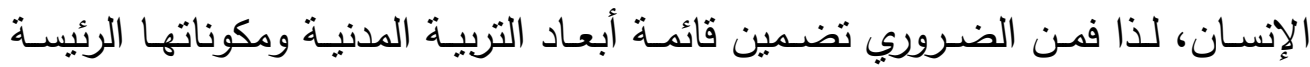
والفرعية التي توصل إليها البحث، دن هنا اهتم التصور المقترح لمحتوى مقرر حقوق الإنسان بما يلى ألى:

- أن يتضمن محتوى مقرر حقوق الإنسان موضوعات تنتاول المعارف والمعلومات المرتبطة بالتربية المدنية، منل: مبادئ القانون الدولي وحقوق الإنسان، الدستور المصرى ومبادئه، المواطنة، الديمقراطية، المجتمع المدني، المشاركة السياسية، المشاركة المجتمعية، العدالة الاجتماعية. - أن بتضمن المحتوى بابًا مستقلاً لعرض حقوق الإنسان في الثربعة الإسلامية، مع التركيز على كيفية ممارسة هذه الحقوق وكيفية تطبيق هذه المبادئ بصورة عملية بما يتلائم مع التغيرات المجتمعات المعاصرة. - الاهتمام بتضمين المحتوى بعض قضايا المجتمع ومشكلاته المرتبطة بحقوق الإنسان والتربية للمواطنة، مع إتاحة الفرصة للطالب لتكوين رأى حول هذه بهن القضايا، وإمكانية الإسهام في إيجاد حلول لبعضها.

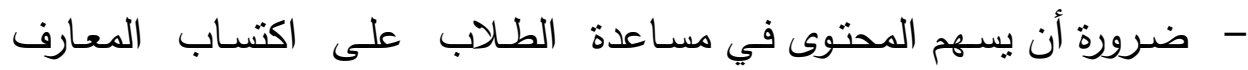
والمعلومات المتعلقة بحقوق الإنسان والتربية المدنية بصورة وظيفية، حيث يتم بناء المعارف من قبل الطلاب، وتوسيعها وربطها بحياتهم الواقعية، وبالنالي يصبح التعلم لله معنى بالنسبة للطالب.

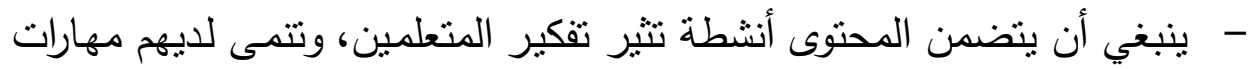

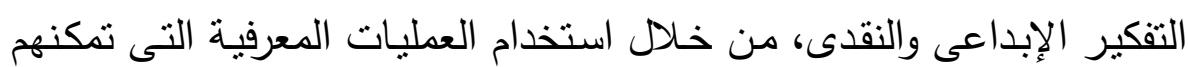
من فهم وشرح ومقارنة وتقييم ممارسات الحكومة، بما يمكنه من إصدار أحكام واعية عن الحكومة والسياسة. 
دراسة تقويمية لمقرر حقوق الإنسان بالمرحلة الجامعية في ضوء مرتكزات التربية المدنية د. محمد حسين على حمدان

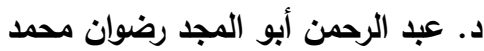

- أن يتم تتظيم محتوى مقرر حقوق الإنسان وعرض موضوعاته بصورة تضمن تأصيل قيم المواطنة والانتماء لدى الطلاب، وتتمى لديهم المسئولية الاجتماعية والقدرة على ممارسـة مسـؤلياته الاجتماعيـة نحو نفسـه والآخرين، مـع زيـادة الوعى بالعلاقة بين الحقوق والواجبات.

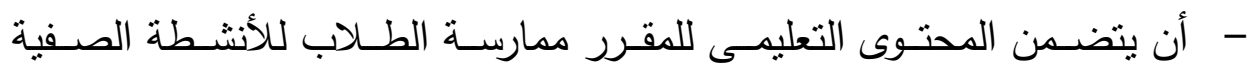
واللاصـفية المختلفـة التى تتـجعهم على المشـاركة في الندوات والمـؤتمرات السياسـية، بمـا بمكنهم مـن المتابعـة السياسـية للقضـايا والأحداث، واكتشـاب

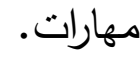

- - ضرورة أن لا يكون الاهنمام بالجوانب النظرية في محتوى المقرر على حساب الجوانب التطبيقية للمعارف والمهارات والقيم المدنية في حياة الطلاب، ودون

$$
\text { إهمال لحاجاتهم وميولهم. }
$$

تم اختيار استراتيجيات وطرق التدريس التى تتناسب مع طبيعة محتوى مقرر حقوق الإنسان، حيث ركز التصور المقترح على استراتيجيات وطرق التدريس القائمـة على فلسفة التعلم النشط باعتبارهـا تؤكد على الطالب كمحور لعملية التعلم، وتهنت

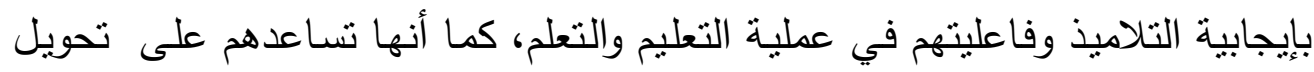

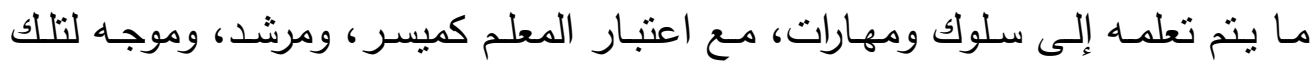

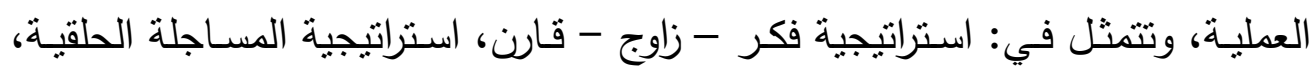
استراتيجيات ما وراء المعرفة ومنها: التدريس التبادلي واستراتيجية ما أعرفه - ما أريد

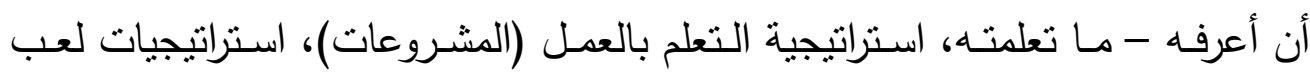

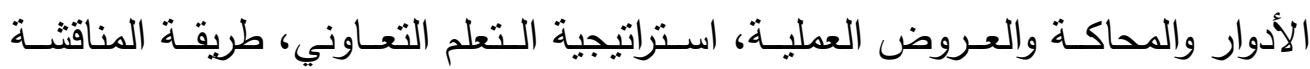
والعصف الذهنى. 
دراسة تقويمية لمقرر حقوق الإنسان بالمرحلة الجامعية في ضوء مرتكزات التربية المدنية د. ال محمد حسين على حمدان

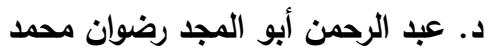

( ) ( الأنشطة التعليمية:

ترتبط فاعلية استراتيجيات وطرق التنريس بتفعيل الأنشطة الصفية واللاصفية، من خلال الاهتمام بالأنشطة الهادفة إلى إبراز الجوانب التنريعية والقانونية والاجتماعية لصالح التربية على حقوق الإنسان، من خلال: - عقد الندوات والمناظرات العلميـة التى تتتـاول قضـايا حقوق الإنسان والتزبيـة المدنية المختلفة. - تشجيع الطلاب على استخدام الوسائط التكنولوجية الحديثة والانترنت في عمل التهل الأبحاث المختلفة النى تتناول موضوعات التربية المدنية. - تقسيم الطلاب إلى مجموعات عمل تعاونية لعمل مجلات حائط تتناول قضايا: المواطنة والديمقراطية وحرية الفكر وعدم التمييز، وغيرها من القضايا المرتبطة بالتربية المدنية. - اسـتخدام العـروض التقديميـة والأقـراص الدمدجـة لعـرض التجـارب الدوليــة والمحلية المختلفة في مجال حقوق الإنسان والتربية للمواطنة.

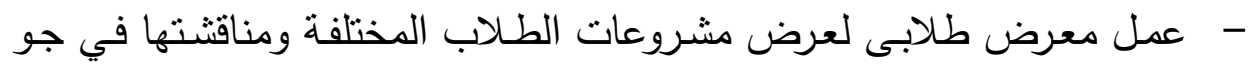

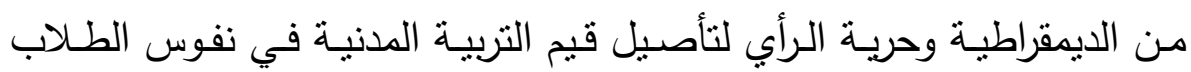
بشكل عملى. (0) (0) مصادر التطلم المقترحة: هى المصادر التى يمكن للطلاب الرجوع إليها غير الكتاب الدقرر، وهى كل

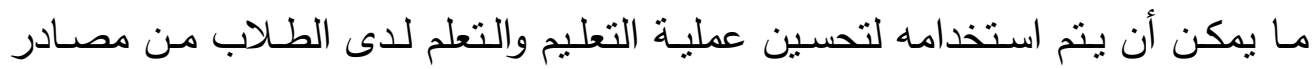

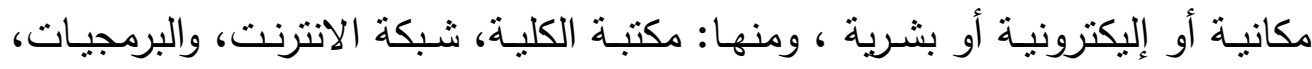

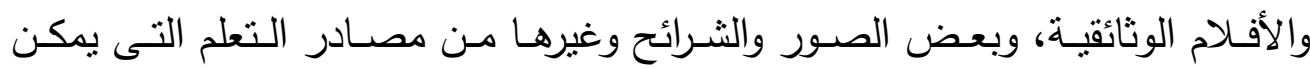
الاستعانة لعرض الممارسات العالمية والمحلية لحقوق الإنسان وقضايا التربية المدنية. 
دراسة تقويمية لمقرر حقوق الإنسان بالمرحلة الجامعية في ضوء مرتكزات التربية المدنية د. محمد حسين على حمدان د. عبد الرحمن أبو المجد رضوان محمد لديد

( ( ) أساليب وأدوات التقويم:

عملية تقويم تعلم الطلاب، تعد عنصرًا مهمًا لنجاح المقرر في تحقيق أهدافه،

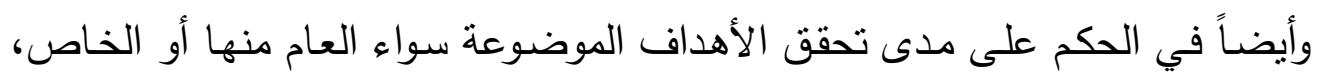
لذلك ينبغى ألا يقتصر تقويم مقرر حقوق الإنسان على الجانب المعرفي فقط ، ولكن يتعداه ليشـمل الممارسـة والسلوك وتقويم الجانب المهاري والقيمي للتربيـة المدنية، مـع إعطاء الحريـة للطلاب لعرض أدائهم بكل حرية، ومناقتشتها بموضوعية، في جو من الديمقراطية واحترام الآراء، ويتبنى التصـور المقترح عمليات التقويم المبدئي والبنائي والتقويم النهائي وتفعيلها، ويوضح الجدول التالي الأساليب والأدوات المقترحة في تقويم

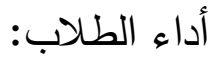

جدول (V) أساليب التقويم المقترحة بالتصور المقترح

\begin{tabular}{|c|c|c|}
\hline أبعاد التعلم التى يقيسها & أساليب التقويم المقترحة & b \\
\hline معرف ومهارات التربية المدنية & الاختبارات التحريرية والثفوية المقننة & 1 \\
\hline معارف ومهارات وقيم التربية المدنية & ملفات الإنجاز & r \\
\hline قيم التربية المدنية & مقاييس الاتجاه والميول & $r$ \\
\hline معارف ومهارات التربية المدنية & بطاقات الملاحظة & $\varepsilon$ \\
\hline معارف ومهارات التربية المدنية & كتابة البحوث والمقالات & 0 \\
\hline قيم التربية المدنية & المشاركة في الأنشطة التوعوية والندوات & 7 \\
\hline
\end{tabular}


دراسة تقويمية لمقرر حقوق الإنسان بالمرحلة الجامعية في ضوء مرتكزات التربية المدنية د. محمد حسين على حمدان

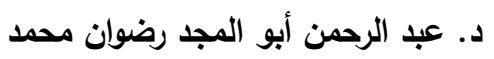
توصيات البحث : في ضوء ما سبق يوصي البحث بما يلي:

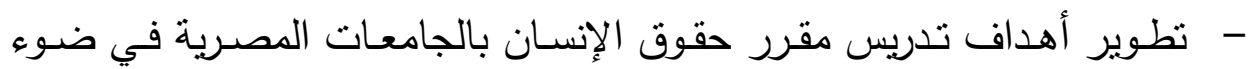
مرتكزات التربية المدنية. - الاستفادة من التصور المقترح الذى تم تقديمه وإعادة تقييمه ومراجعته وتطويره من قبل مصصمي البرامج والمقررات الجامعية. - الاهتمام بتتمية المهارات والقيم الضرورية لتعزيز التربية المدنية ومبادئ حقوق الإنسان، والدفاع عنها وتطبيقها فى الحياة اليومية، جنبًا إلى جنب مـع تتمية المعارف المتعلقة بحقوق الإنسان وبآليات حمايتها. - - إقامـة نـوادى لحقوق الإنسـان والتربيـة للمواطنـة داخـل الجامعـات المصـرية، مهمتهـا نشر الوعي بـالحقوق والحربات وتدعيم مرتكزات التربيـة المدنية، من خـل الأنشطة الثقافيـة والمؤتمرات الحقوقيـة المختلفة، وأن يكون النادي جزءً من الحياة الجامعيـة، ويسـاهم في تحقيق مقرر حقوق الإنسـان لأهدافه، من خلال صقل مهارات الطلاب وإعدادهم للحياة النشيطة الفاعلة والمسئولة. - الاهتمـام بعمـل زيـارات ميدانيـة لطـلاب الجامعـة لمنظمـات المجتمـع المـدنى

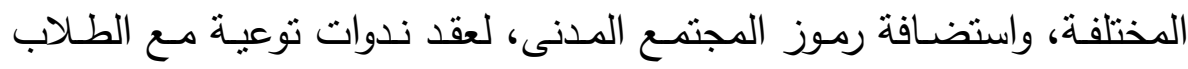

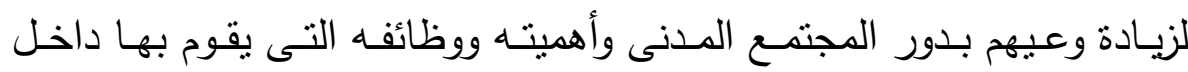
المجتمعات الديمقراطية. - واحترام حربـة الفكر والآخـر ، والمسـاوة وعدم التمييز مـع تخصـيص جـوائز لأفضل فريق عمل، بهدف تشجيع الطلاب على البحث في هذه القضايا وتقديم حلول لها. - - ضرورة أن تكون الأنشطة المتضمنة في مقرر حقوق الإنسان أنشطة عملية،

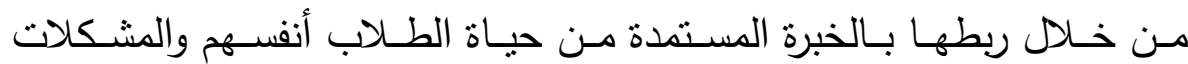


دراسة تقويمية لمقرر حقوق الإنسان بالمرحلة الجامعية في ضوء مرتكزات التربية المدنية د. محمد حسين على حمدان د. عبد الرحمن أبو المجد رضوان محمد لديد

المجتمعية المحيطة بها، مما يمكنهم من تحديد ومعالجة احتياجاتهم في مجال حقوق الإنسان، والاستفادة من دراسة المقرر في تقديم حلول واقعية للمشكلات والقضايا المجتمعية المرتبطة بالتربية المدنية.

$$
\text { البحوث المقترحة : }
$$

في ضوء ما توصل إليه البحث الحالي من نتائج وتوصيات يقترح ما يلي: - إجـراء دراسـة تقويميـة لمقرر حقوق الإنسـان في المرحلـة الثانويـة في ضـوء مرتكزات التربية المدنية.

- فاعلية برنامج مقترح في ضوء مرنكزات التربية المدنية لتتمية فيم المواطنة لدى

$$
\text { طلاب الجامعة. }
$$

- - دور مقرر حقوق الإنسان في تتميـة أبعاد ومكونات التربية المدنية من وجهة نظر طلاب الجامعة.

- تطوير مقرر حقوق الإنسان بجامعة جنوب الوادي في ضوء المعايير العالمية لحقوق الإنسان. 
دراسة تقويمية لمقرر حقوق الإنسان بالمرحلة الجامعية في ضوء مرتكزات التربية المدنية د. محمد حسين على حمدان د. عبد الرحمن أبو المجد رضوان محمد لديد

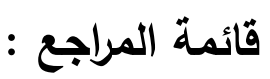

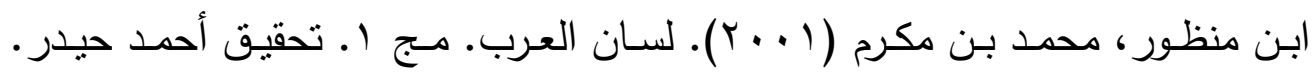
لبنان: دار الكتب العلمية.

أبو الكاس، رائد محمد (10 • ب). الخبرات العالميـة لتربيـة المواطنـة وكيفيـة الاستفادة

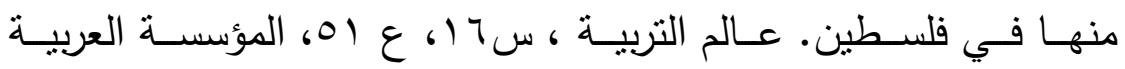

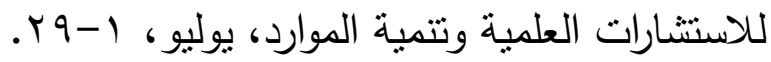

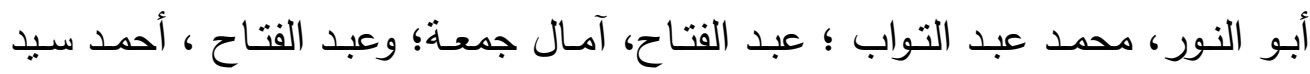

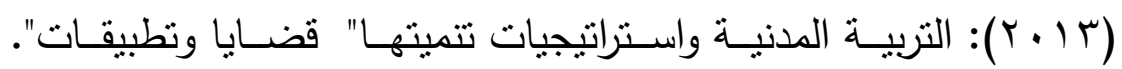
القاهرة: دار الفكر العربى.

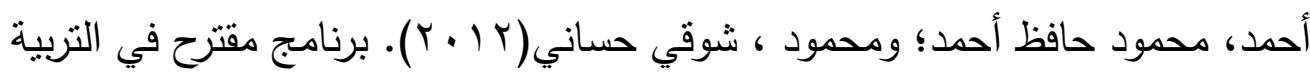

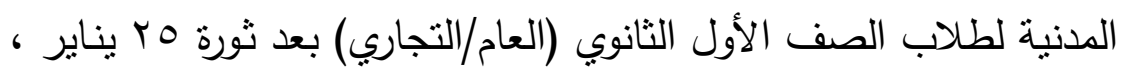

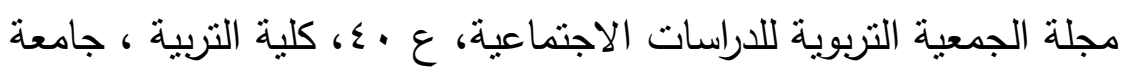

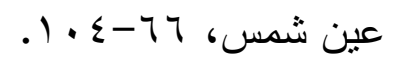

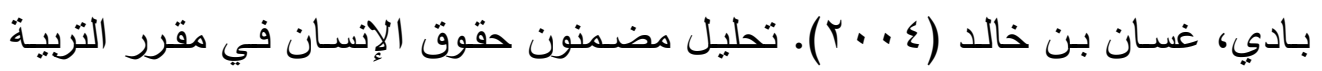

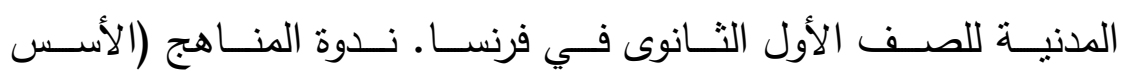

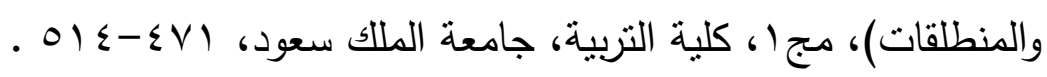
بدران، شبل (9 . . ب). التربية المدنية التعليم والمواطنة وحقوق الإنسان. القاهرة: الهيئة المصرية العامة للكتاب.

بوسنينة، المنجي (T + . ب أبريل). آفاق تطوير التربية المدنية في المنظومـة التربويـة العربية. الملتقي العربي الثالث للتربية والتعليم " التعليم والتربية المستدامة لئه

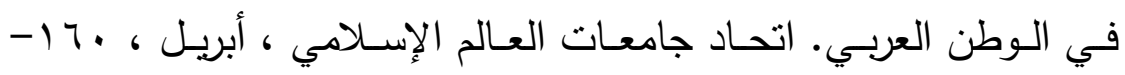
. YVI

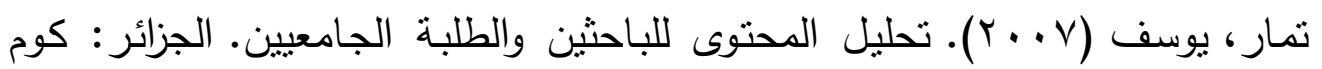
للارراسات والنشر والتوزيع. 
دراسة تقويمية لمقرر حقوق الإنسان بالمرحلة الجامعية في ضوء مرتكزات التربية المدنية

د. محمد حسين على حمدان د. عبد الرحمن أبو المجد رضوان محمد لديد

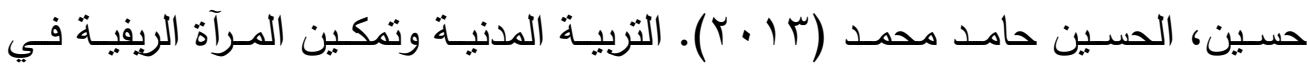

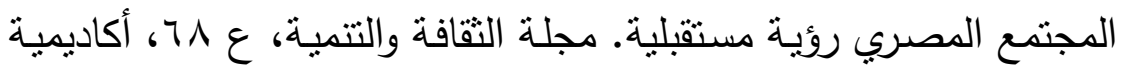
البحث العلمي والتكنولوجيا بالقاهرة، مايو ، اب | - . 1 |.

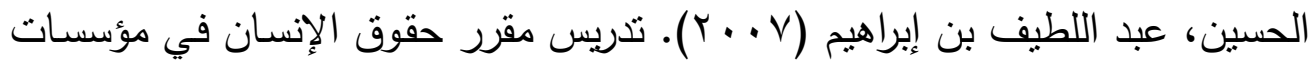

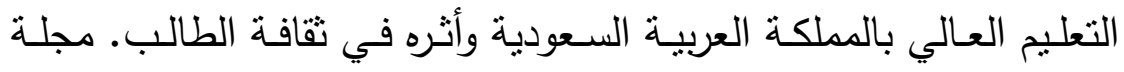

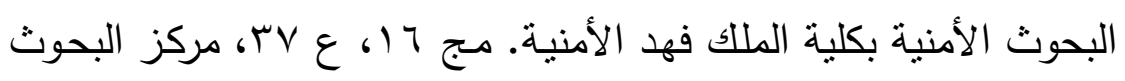
والدراسات، كلية الملك فهد الوطنية، 10 - 10 .

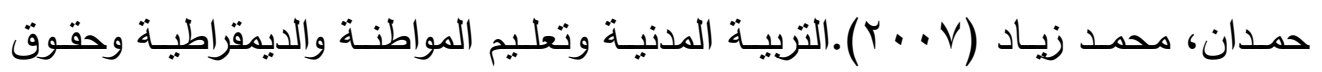

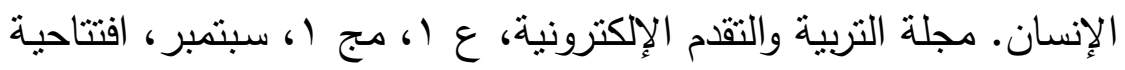

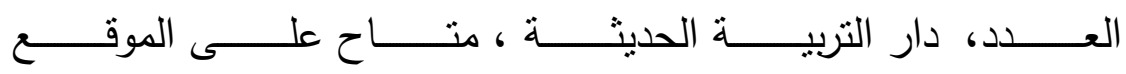
http://hamdaneducation.com/index.php?route=common/ $\underline{\text { home }}$ خوالدة، ناصر أحمد (T . . ب). تحليل المحتوى في مناهج التربية الإسـامية. عمان: دار وائل للنشر.

خيـري، منـال محمـود (r (Y). فاعليـة برنـامج مقترح في حقوق الإنسـان لطـلاب المدارس الثانويـة التجاريـة وأثرة علي تتميـة واكتشـاب المفـاهيم والقضـايا

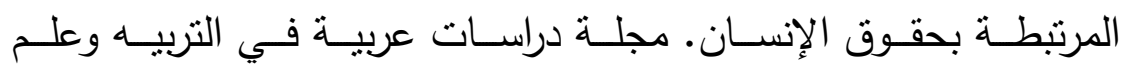

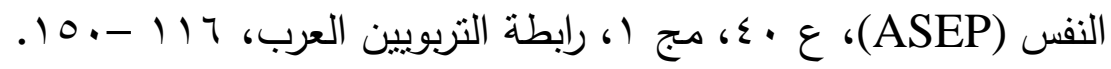
درويش، عطا حسن( • ( • ). مدي نجاح منهاج التربية المدنية في خلق نقافة مدنية

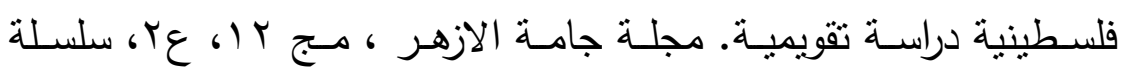

$$
\text { العلوم الإنسانية، غزة، سمبنه }
$$

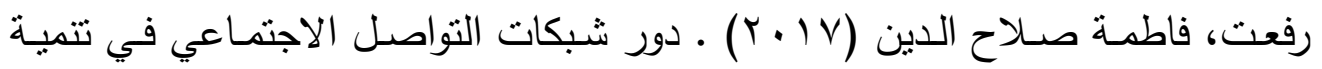

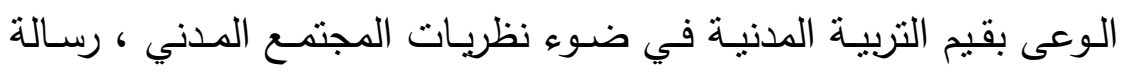

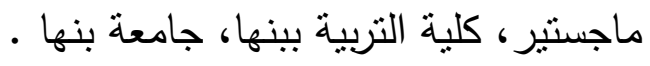
شحاته، حسن (9 . . ץ: يوليو). منهجية وتقنية تحليل الكتاب المدرسي. المؤتمر العلمى التاسـع للجمعيـة المصرية للقراءة والمعرفة: كتب تعليم القراءة في الوطن 
دراسة تقويمية لمقرر حقوق الإنسان بالمرحلة الجامعية في ضوء مرتكزات التربية المدنية

د. محمد حسين على حمدان د. عبد الرحمن أبو المجد رضوان محمد دئ دون الإسدان

العربي بين الإنقرائية والإخراج، الجمعية المصرية للقراءة والمعرفة، جامعة

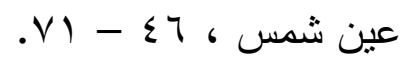

شقورة، فداء احمد حسن (10 ب ب). أثنر إثراء محتوى كتاب التربية المدنية في تتمية قيم الحوار لدى طلبة الصف الرابع الأساسي. رسالة ماجستير، كلية التربية

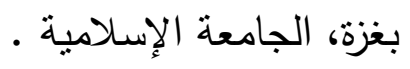

صحراوى، بوزيهـ (؟ . . ب). المنهاج التعليمى والتدريس الفعـال. الجزائر : دار القصبة

$$
\text { للنشر والتوزيع. }
$$

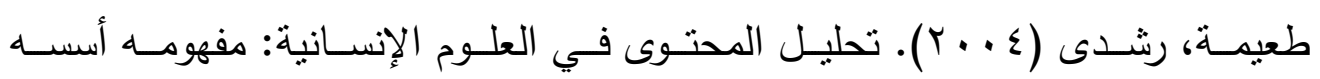

$$
\text { واستخداماته. القاهرة: دار الفكر العربي. }
$$

عـامر، طـارق عبد الـرؤوف (11 ـ ب): المواطنـة والتربيـة الوطنيـة "اتجاهـات عالميـة وعربية. القاهرة: مؤسسة طيبة للنشر والتوزيع.

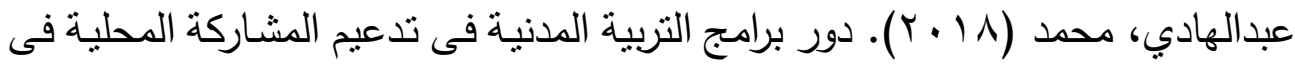

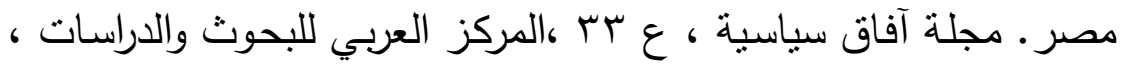

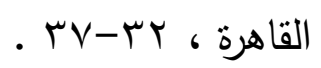

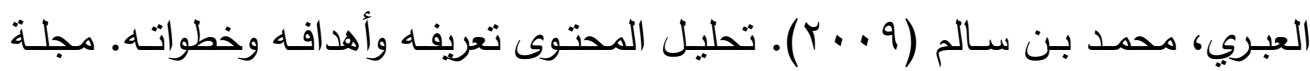

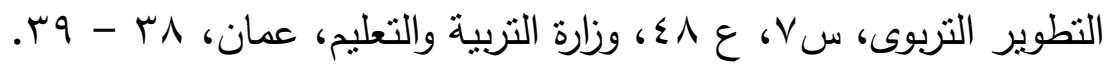

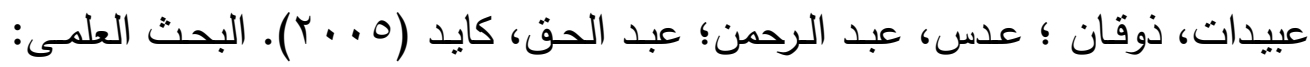
مفهومه وأدواته وأساليبه. الرياض: داضد دار أسامة للنشر والتوزيع. العساف، صالح بن حمد (990 (1). المدخل إلى البحث في العلوم السلوكية. الرياض : مكتبة العبيكان.

على، محمد السيد (T ( • ب). دور التربية المدنية فى تعزيز قيم الانتمـاء ومسئوليات المواطنة لاى طلاب المرحلة الثانوية، رسالة ماجستير غير منشورة، كلية التربية، جامعة المنصورة.

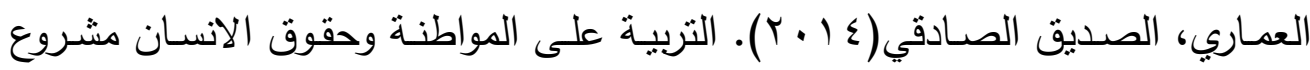

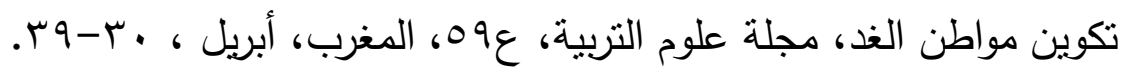


دراسة تقويمية لمقرر حقوق الإنسان بالمرحلة الجامعية في ضوء مرتكزات التربية المدنية

د. محمد حسين على حمدان

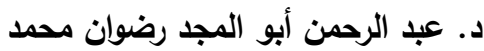

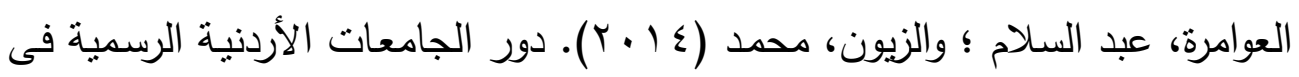
تعزيز تربية المواطنة وعلاقتها بتتمية الاستقلالية الذاتية لاى طلبة كليات

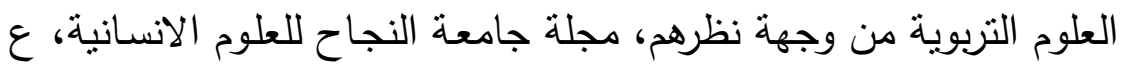

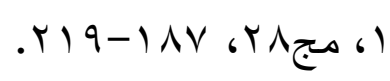

فراج، محسن حامد؛ وعتيبة، آمال محمد (T ( • Y). تصور مقترح لتدريس وتعليم حقوق الإنسان لطلاب الجامعات بالمملكة العربية السعودية. بحث علمي ممول

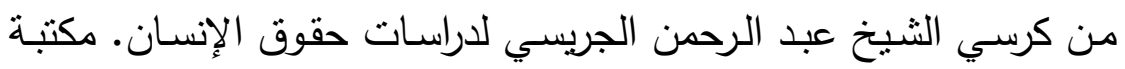
الملك فهد الوطنية: جامعة الإمام محمد بن سعود الإسلامية .

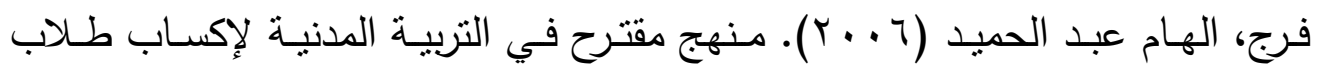

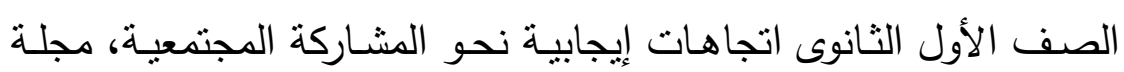

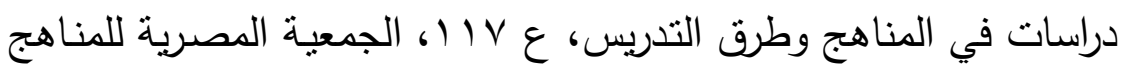

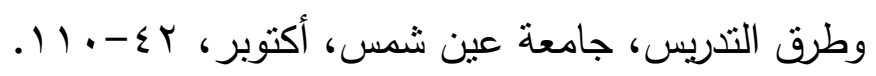

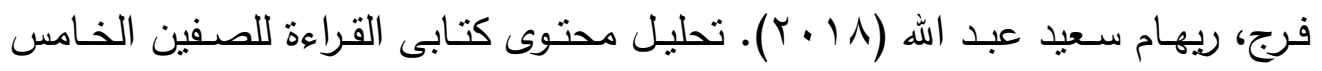

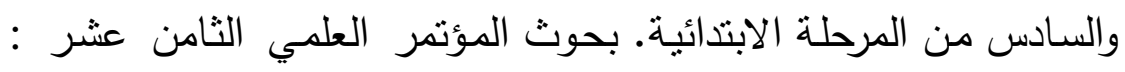

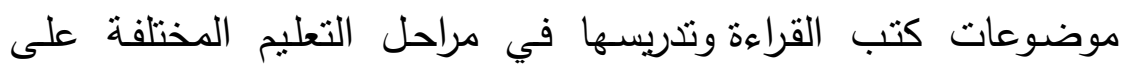

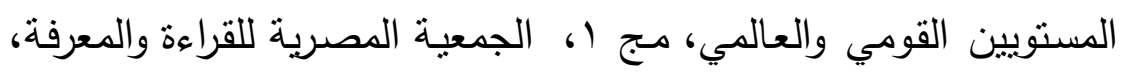
جامعة عين شمس،

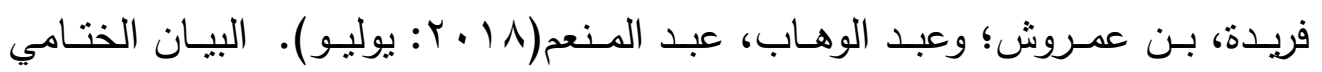
وتوصيات الملتقي الدولي ـ الملتقي الدولي السنوي للبحث العلمي بعنوان"

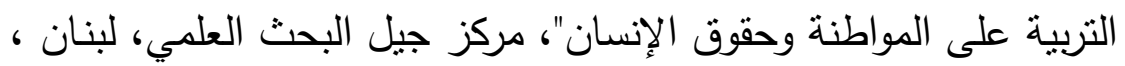

$$
\text { .rqV-rqr }
$$

قاسم، مصطفى محمد عبد الله (T + . ץ). التعليم والمواطنة واقع التربية المدنية في في المدرسة المصرية. القاهرة : مركز القاهرة لدراسات حقوق الإنسان.

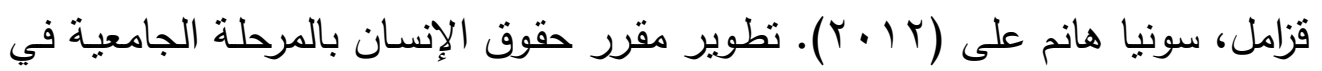
ضوء طبيعة الدراسة بكليات التربية. مجلة دراسات عربية في التربيه وعلم الإسيان بالمريه

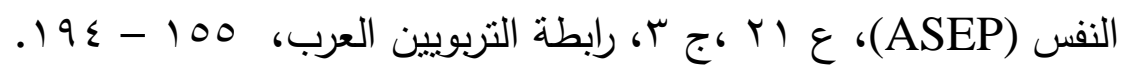


دراسة تقويمية لمقرر حقوق الإنسان بالمرحلة الجامعية في ضوء مرتكزات التربية المدنية

د. محمد حسين على حمدان د. عبد الرحمن أبو المجد رضوان محمد لديد

اللوزي، أرزاق محمد عطيه (1 ( • Y). فاعليـة وحدة دراسية مقترحسة قائمـة على أبعاد التربية المدنية بمنهج التربية الأسرية في تتمية قيم الأمن الفكري ومهارات

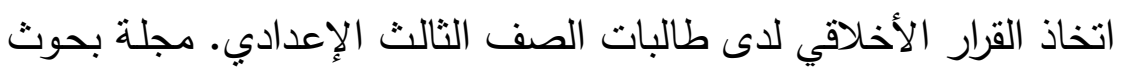
عربية في مجالات التربية النوعية، ع 9، رابطة التربوبين العرب، سجائ $.11 \%$

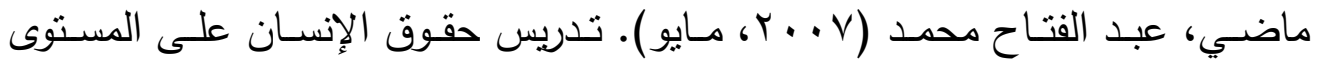

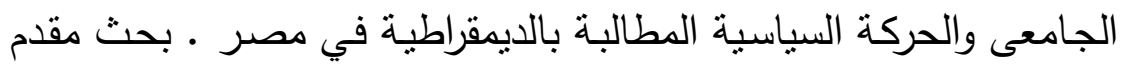

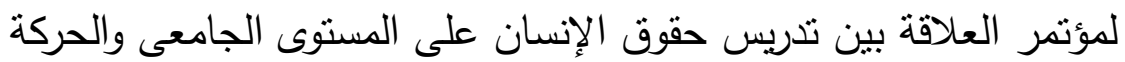

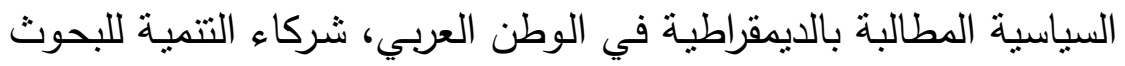

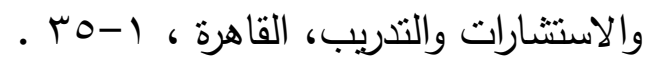

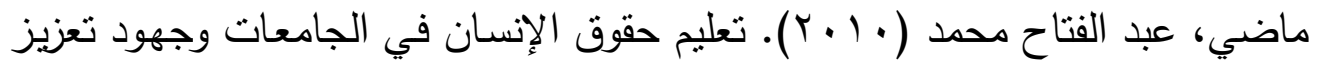

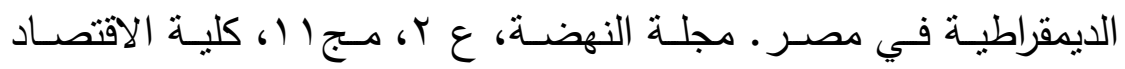

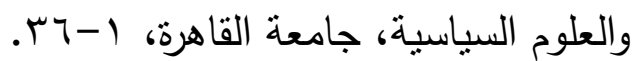

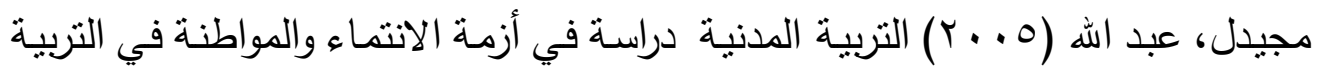

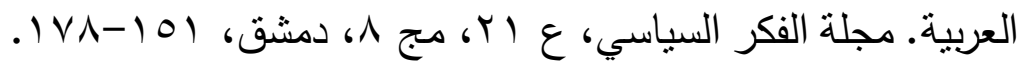

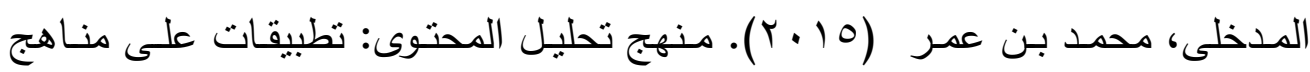
البحث. جامعة الملك عبد العزبز : كلية المعلمين بجدة. مرتجي، زكي رمزي ؛ والرنتيسى، محمود محمد (11 (1): تقييم محتوى مناهج التربية المدنية للصفوف السابع والثامن والتاسع الأساسي في ضوء قيم المواطنة،

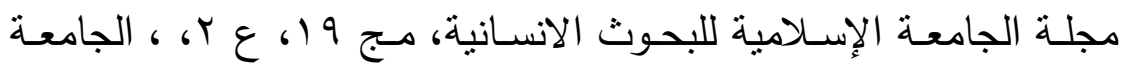

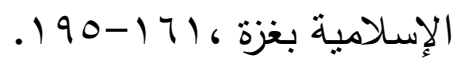

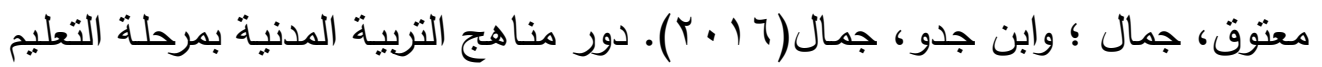

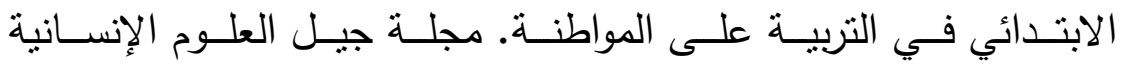

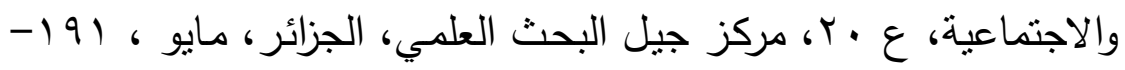
$r \cdot \Lambda$ 
دراسة تقويمية لمقرر حقوق الإنسان بالمرحلة الجامعية في ضوء مرتكزات التربية المدنية د. محمد حسين على حمدان د. عبد الرحمن أبو المجد رضوان محمد لديد

المقاطي، صالح بن إبراهيم (1 ( • rم). مدى تضمين مفاهيم حقوق الإنسان في مقرر

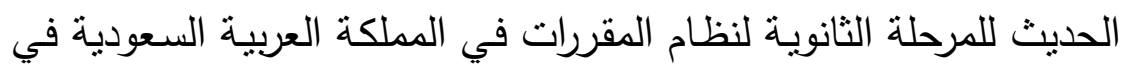
ضـوء مشـروع إعـانان حقـوق الإنسـان لمجلس التعـاون (دراسـة تحليـل

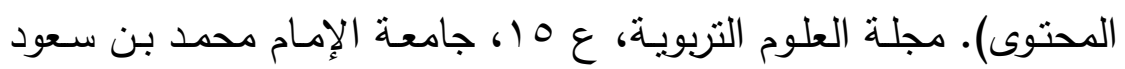

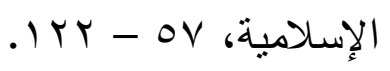

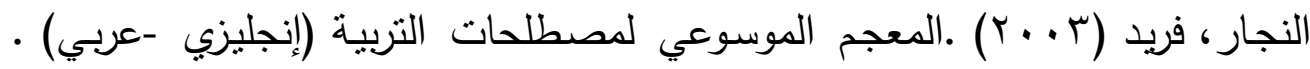

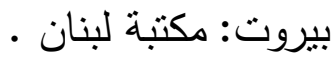

نجيب، كمال (10 • ب). التربية المدنية في مصر الحاضر وطموحات المستقبل. مجلة

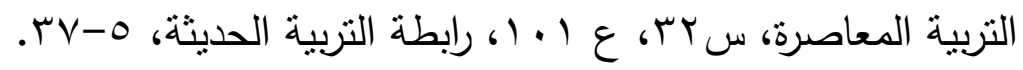

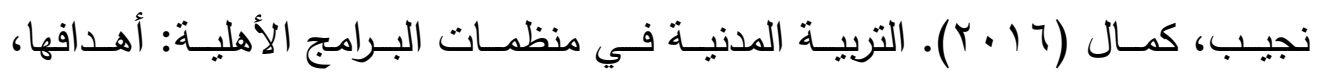

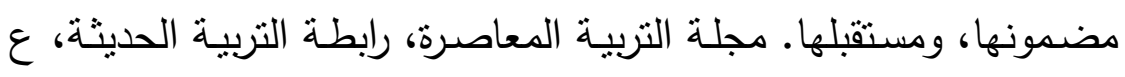

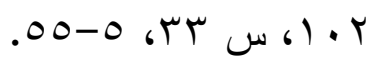

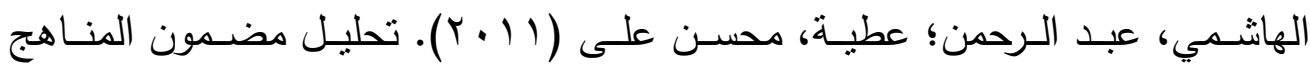
المدرسية. عمان: در صفاء للنشر. 
دراسة تقويمية لمقر حقوق الإنسان بالمرحلة الجامعية في ضوء مرتكزات التربية المدنية

د إ. محمد حسين على حمدان

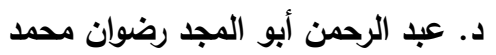

Center for Civic Education and funded (2010) .National Standards for Civics and Government, Center for Civic Education, Calabasas, California, retrieved at 20 Jan 2019,Available at,www.civiced.org.

Civic Mission of Schools report (2003 ).Guardian of Democracy: the Civic Mission of Schools, Carnegie Corporation of New York and the Center for Information and Research on Civic Learning and Engagement. this report are available online at: www.civicmissionofschools.org,

Doganay, Ahmet (2012): A Curriculum Framework For Active Democratic Citizenship Education, In: M. \& lange, D. (eds.) Schools, Curriculum and Civic Education for Building Democratic Citizens. Civic and Political education Series, Taipei Sense Publishers, Rotterdam, Boston.

Parker,W.(1996).Curriculum for Democracy, In: Roger.S. (ed.) Democracy ,Education, and the School,sanfrancisco,183-210.

Patrick, J.(2002). Improving Civic Education in Schools. ERIC

Clearinghouse for Social Studies/Social Science Education Bloomington IN.

Ross, A. (2012). Education for active citizenship: practices, policies, promises. International Journal of Educational Research , 8 (3),7-14.

Shabani, F. (2013). The civic education as a specific function of Institute of Education in contemporary Iran, retrieved at 20 Jan 2019.Available at fromysu.am/files/07F_Shabani.pdf. 
دراسة تقويمية لمقرر حقوق الإنسان بالمرحلة الجامعية في ضوء مرتكزات التربية المدنية

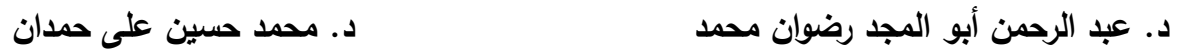

Shorten, A.(2010). Cultural Diversity and Civic Education: Two Versions of the Fragmentation Objection, Educational Philosophy and Theory, v42, n1, 57-72, Available online at:http://www.Eric.EJ870000.

Sodr,R.(1997).Democracy do we Really Want it the public purpose of Educational and Schooling, san Francisco,Jossy-Bass publishers.

Stanford Encyclopedia of Philosophy(2007,Dec),Civic Education, retrieved at 20 Jan 2019,Available at https: //plato .stanford .edu /entries/civic-education/. 